\title{
Hereditary Angioedema in Sweden - a National Project
}

\author{
Patrik Nordenfelt
}

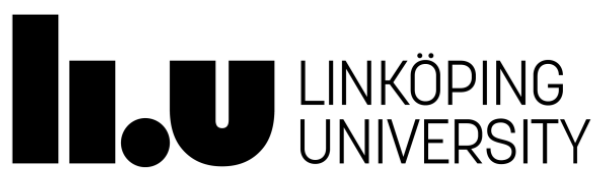

Department of Clinical and Experimental Medicine

Faculty of Medicine and Health Sciences,

Linköping University,

SE-581 83 Linköping, Sweden 
CPatrik Nordenfelt, 2017

Picture of C1-inhibitor on the cover made by NGL Viewer published in:

AS Rose, AR Bradley, Y Valasatava, JM Duarte, A Prlić and PW Rose. Web-based molecular graphics for large complexes. ACM Proceedings of the 21 st International Conference on Web3D Technology (Web3D '16): 185-186, 2016.

AS Rose and PW Hildebrand. NGL Viewer: a web application for molecular visualization. Nucl Acids Res (1 July 2015) 43 (W1): W576-W579 first published online April 29, 2015

Published articles have been reprinted with the permissions of the copyright holder.

Printed in Sweden by LiU-Tryck, Linköping, Sweden, 2017

ISBN: 978-91-7685-430-3

ISSN: 0345-0082 
"The good physician treats the disease; the great physician treats the patient who has the disease."

William Osler

For the patients and their families 



\section{Content}

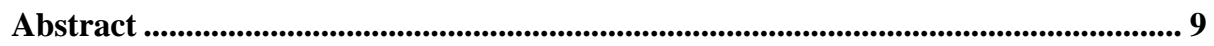

Populärvetenskaplig sammanfattning ............................................................................... 11

List of Studies........................................................................................................................... 13

Abbreviations ................................................................................................................. 15

Introduction ............................................................................................................................... 17

History of hereditary angioedema .................................................................. 17

Pathophysiology and classification of HAE ......................................................... 18

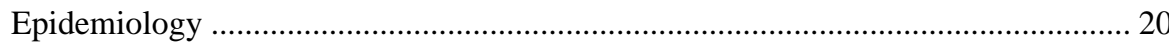

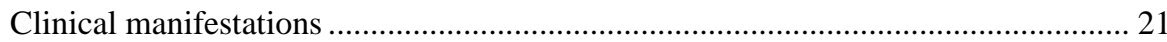

Diagnosis of HAE type I/II............................................................................. 22

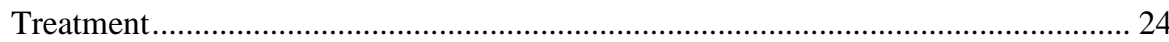

Health-related quality of life............................................................................ 25

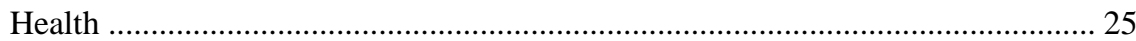

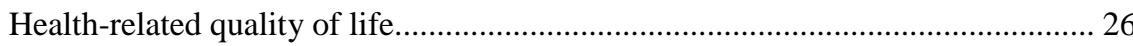

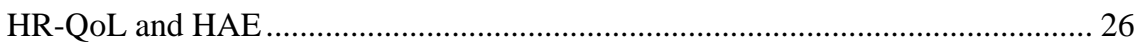

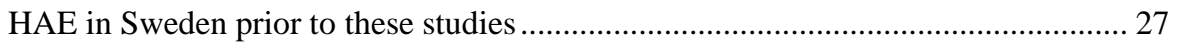

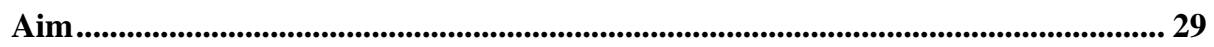

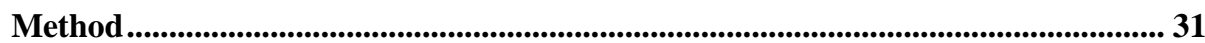

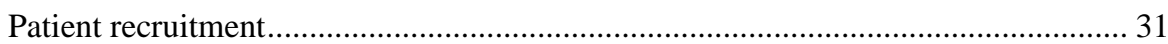

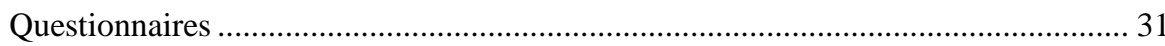

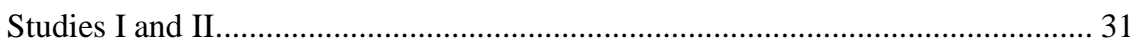

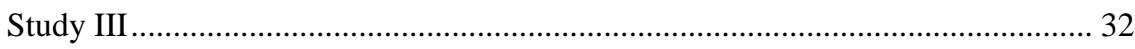

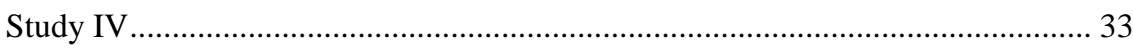

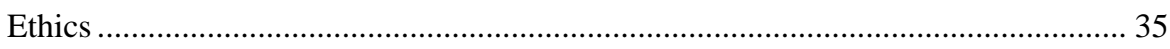

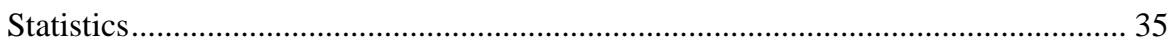

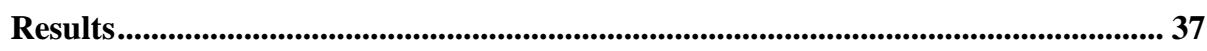

Response rate, demographics, HAE type and family history (studies I and II) ......... 37

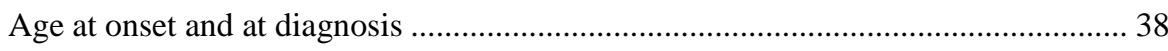

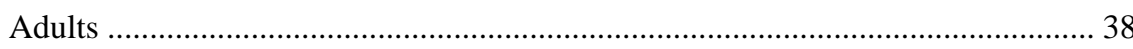

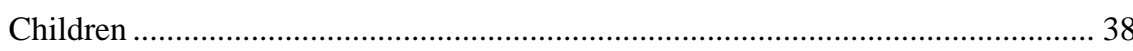


Overall 38

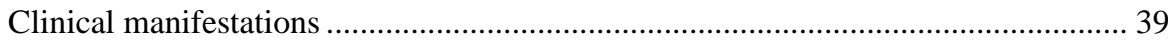

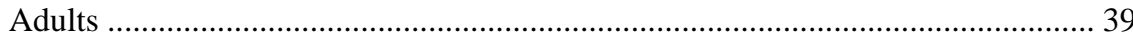

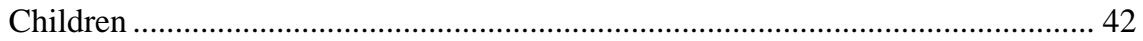

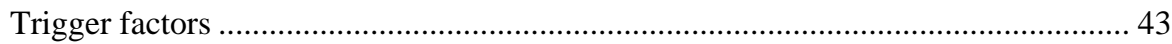

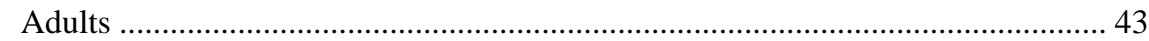

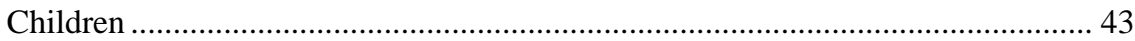

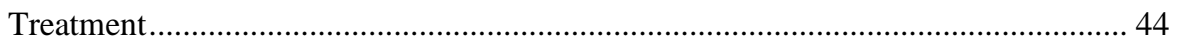

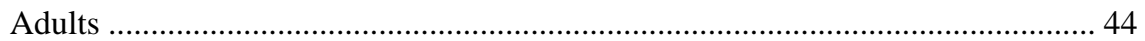

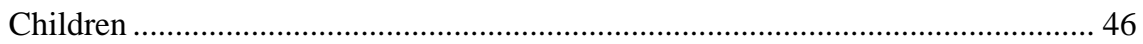

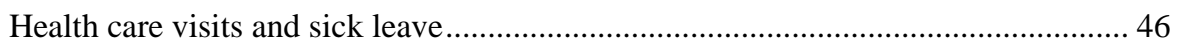

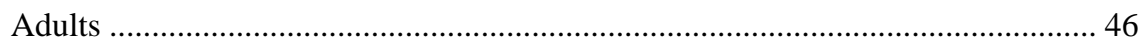

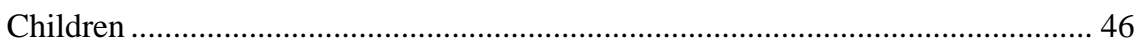

Quality of life and health assessment: children (study II) .......................................46

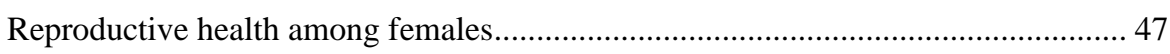

HR-QoL in patients with HAE: EQ-5D-5L during and between attacks (studies III

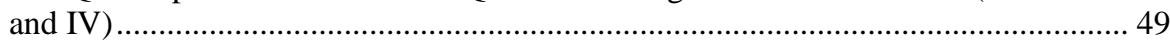

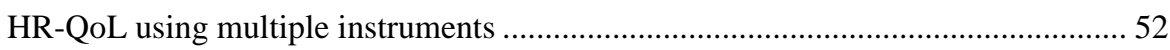

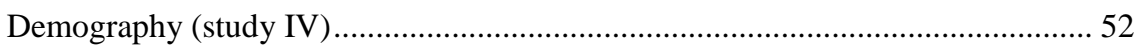

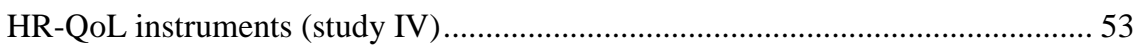

Associations between EQ-5D-5L or RAND-36 and AE-QoL (study IV).............. 55

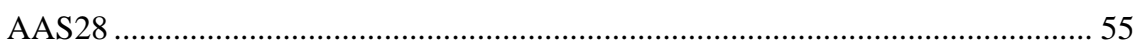

Associations between AAS28 and HR-QoL instruments..................................... 58

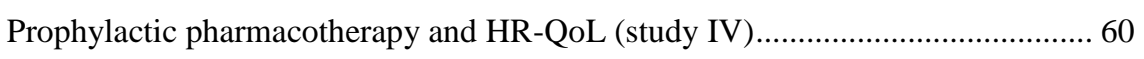

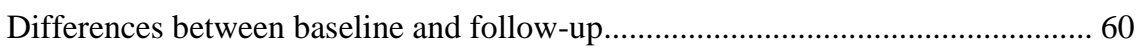

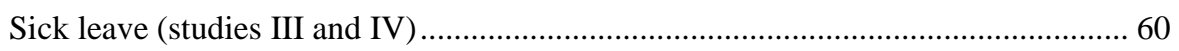

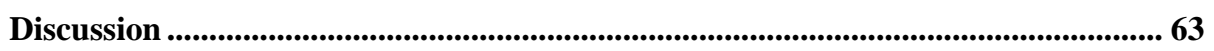

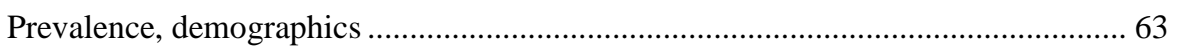

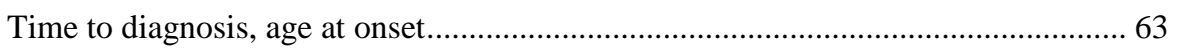

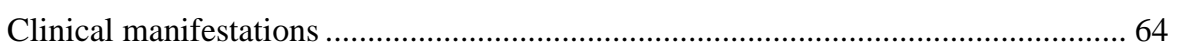

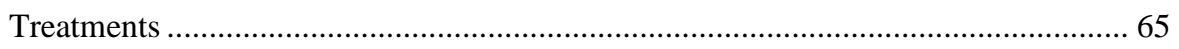

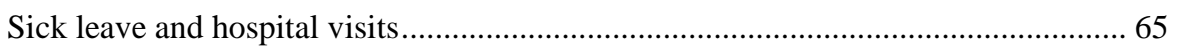

Differences between males and females and reproductive health in females ............. 65 


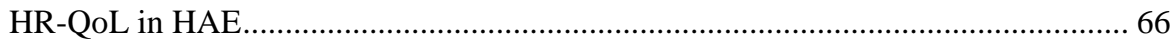

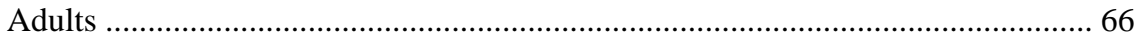

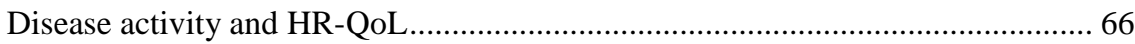

Comparison with other diseases and normal population .................................... 67

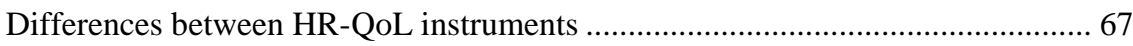

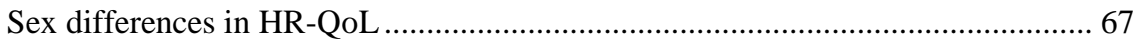

Prophylactic pharmacotherapy, HR-QoL and disease activity..............................6 68

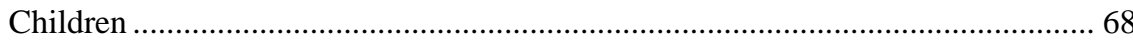

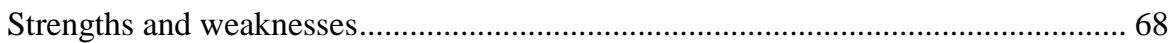

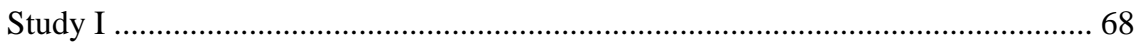

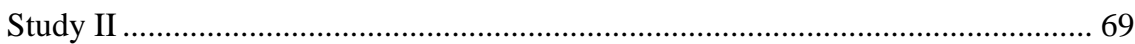

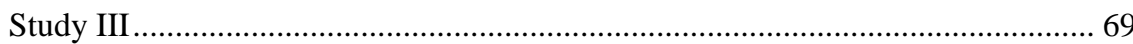

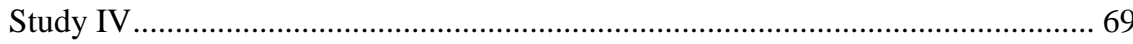

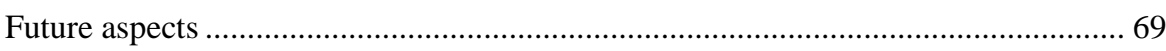

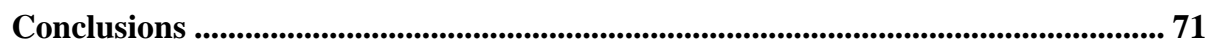

Acknowledgement....................................................................................................... 73

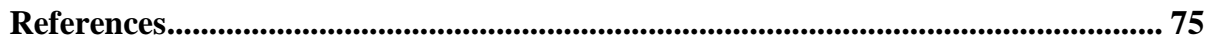

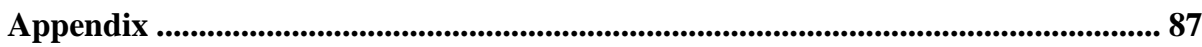

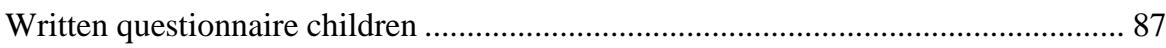

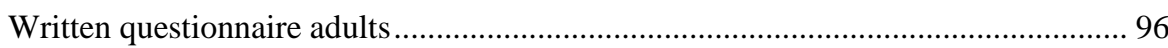

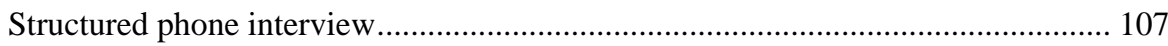




\section{Abstract}

Background: Hereditary angioedema (HAE) due to C1-inhibitor deficiency, type I and II, is a rare disease with an estimated prevalence of $1 / 50,000$. Angioedema in the larynx can be life threatening and angioedema in the abdomen and skin can give severe and disabling pain. Data on patients with HAE in Sweden were scarce before our study.

Aim: To study the prevalence of HAE, and to investigate clinical manifestations, treatments, and Health-Related Quality of Life (HR-QoL) in adults and children in Sweden.

Method: In studies, I and II, all patients received a written questionnaire followed by a phone interview with questions about clinical manifestations, medication, sick leave and QoL. In study III the patients completed EuroQol 5 Dimensions 5 Levels (EQ-5D-5L) questionnaires for both the attack-free state (EQ5D today), and the last HAE attack (EQ5D attack). Questions were also asked about sick-leave. In study IV all adults received questionnaires with EQ-5D-5L and RAND-36, Angioedema Quality of Life instrument (AE-QoL), and Angioedema Activity Score (AAS) form, and questionnaires on sick leave and prophylactic medication.

Results: We identified 146 patients, 110 adults and 36 children with HAE, type I $(n=136)$ or II $(n=10)$, giving a minimal HAE prevalence of $1.54 / 100,000$. For adults, the median age at onset of symptoms was 12 years and median age at diagnosis was 22 years. Median age at onset of symptoms for children was 4 years and at diagnosis 3 years. During the previous year, $47 \%$ of adults experienced at least 12 attacks, $21 \%$ 11 attacks, 11\% 1-3 attacks, while 22\% were asymptomatic. For children, the corresponding figures were about the same. The median number of attacks in those having attacks was 14 in adults and 6 in children last year. Adult females reported on average 19 attacks the previous year versus nine for males. Irrespective of location nine out of 10 reported pain. Trigger factors were experienced in $95 \%$ of adults and $74 \%$ of children. Plasma-derived C1-inhibitor concentrate (pdC1INH) had a very good effect on acute attacks. Long-term prophylaxis with androgens and pdC1INH reduced the annual attack frequency by more than $50 \%$. Of the children's parents, $73 \%$ had been on parental leave to care for the child due to HAE symptoms. Health and QoL were generally rated as good. In study III 103 of 139 responded and reported an EQ5D today score that was significantly higher than the EQ5D attack score. Attack frequency had a negative effect on EQ5D today. Children had significantly higher EQ-5D-5L than adults. Fortyfour percent had been absent from work or school during the latest attack. In study IV 64 of 133 adults responded. The most affected HR-QoL dimensions in EQ-5D-5L were pain/discomfort and anxiety/depression, in RAND-36 energy/fatigue, general health, health transition, pain, and in AE-QoL fears/shame and fatigue/mood. Females had sig- 
nificantly lower HR-QoL in RAND-36 for general health and energy/fatigue. There was an association between AAS and EQ-5D-5L/RAND-36 (except physical function) /AEQoL. There was no significant difference in HR-QoL in patients with and without prophylactic medication.

Conclusion: The minimal prevalence of HAE type I and II in Sweden is 1.54/100,000. Median age at onset was 12 years. Adult females had twice as many attacks as males, adults had also twice as many attacks as children. For acute treatment, pdC1INH had a very good effect. For long term prophylaxis, androgens and pdC1INH had good effect. The most affected HR-QoL dimensions in EQ-5D-5L were pain/discomfort and anxiety/depression, in RAND-36 energy/fatigue, general health, health transition and pain, and in AE-QoL fears/shame and fatigue/mood. Children reported better HR-QoL than adults. AE-QoL is more disease-specific in HAE than the generic instruments EQ-5D5L and RAND-36. However, the latter highlights the pain aspect, whereas AE-QoL does not. Patients with high disease activity should thus be considered for more intensive treatment to improve their HR-QoL. 


\section{Populärvetenskaplig sammanfattning}

Hereditärt angioödem (HAE) är en ärftlig sjukdom med återkommande svullnader (ödem) i underhuden och i submukosan (vävnaden under slemhinnor). Av barnen till en förälder med HAE riskerar hälften att få sjukdomen. Vanliga platser för angioödemen är ansikte, underliv, händer, fötter, svalg, läppar, tunga samt i tarmar. Angioödem i tunga och svalg kan bli livshotande pga. risk för kvävning. I tarmarna ger angioödem ofta svåra handikappande buksmärtor. Obehandlat varar ett angioödem i 3-5 dagar. HAE beror på brist på fungerande C1-inhibitor. Bristen av fungerande $\mathrm{C} 1$-inhibitor beror på mutation i genen för C1-inhibitor. C1-inhibitor hämmar flera system, bl. a kontaktsystemet. När detta aktiveras och C1-inhibitor inte hämmar som det ska bildas bradykinin som gör att kärlen vidgas och blir genomsläppliga och ödem uppstår. Det finns åtminstone två varianter av HAE, typ I där halten av C1-inhibitor är låg, samt typ II där halten av C1-inhibitor är normal eller förhöjd, men proteinet inte fungerar. Det finns även en ännu sällsyntare variant, nämligen HAE typ III eller HAE med normal C1-inhibitor. Vid den sjukdomen är C1-inhibitor normal. Här tas endast patienter med HAE typ I och II upp, då HAE med normal C1-inhibitor är så sällsynt att möjligen finns enstaka fall i Sverige. HAE typ I och II finns hos ungefär 1/50 000. Lika många kvinnor som män får sjukdomen. Kvinnor har oftare mer besvär än män.

Kortison, antihistaminer och adrenalin som ges vid vanliga angioödem har ingen effekt vid HAE. Attacker av HAE behandlas med injektioner in i blodet av C1-inhibitorkoncentrat framställt från blodplasma eller via genteknik från kaninmjölk. Injektioner av icatibant, som blockerar bradykinin kan också behandla angioödem. För att förebygga angioödem kan man behandla med återkommande injektioner med C1inhibitorkoncentrat, eller med tranexamsyra eller androgener i tablettform.

Situationen för HAE i Sverige har tidigare varit i stort sett okänd. Ändamålet med denna avhandling var att få fram hur vanligt HAE är i Sverige, att kartlägga hur sjukdomen yttrar sig, vilken behandling som används, samt vilken hälsorelaterad livskvalitet (HRQoL) vuxna och barn med HAE har.

Patienterna med HAE besvarade enkäter med frågor om sjukdomssymptom, medicinering, och sjukfrånvaro. För att få fram HR-QoL användes livskvalitetsinstrumenten EuroQol 5 Dimensions 5 Level (EQ-5D-5L), RAND Corporation Short Form 36 (RAND-36), och AngioEdema Quality of Life (AE-QoL) och sjukdomsaktivitetsinstrumentet Angioedema Activity Score (AAS).

Vi fann 146 patienter med HAE, 110 vuxna och 36 barn, 136 med typ I och 10 med typ II. Det ger en förekomst på 1,54/100 000. Mittvärdet för när de vuxna började få besvär var 12 års ålder och mittvärdet för diagnosålder var 22 år. Mittvärdet för barnens ålder vid symptomstart var fyra år och för diagnos tre års ålder. Nästan hälften hade mer än ett anfall i månaden föregående år. Mittvärdet för attacker föregående år var för vuxna 14 och för barn 6. Kvinnor angav föregående år 19 attacker mot 9 för män. Oberoende av var attackerna satt angav 9 av 10 smärta under attackerna. C1-inhibitorkoncentrat hade mycket god effekt vid behandling av attacker. Förebyggande behandling med 
androgener och C1-inhibitorkoncentrat mer än halverade attackfrekvensen. Av barnens föräldrar hade mer än $73 \%$ varit tvungna att ta ledigt pga. HAE-attack hos barnet. HRQoL var signifikant bättre mellan anfallen än under anfallen. Vid högre attackfrekvens försämrades HR-QoL. Barn hade en signifikant högre HR-QoL än vuxna. Vid senaste attacken angav $45 \%$ frånvaro från arbete eller skola. Den dimension som var mest påverkad i EQ-5D-5L var smärta/obehag och oro/nedstämdhet, i RAND-36 energi/ trötthet, generell hälsa, smärta, och i AE-QoL rädsla/skam och trötthet/stämningsläge. Förhöjd sjukdomsaktivitet var associerad med försämrad HR-QoL. Oavsett om patienterna hade förebyggande medicin eller ej sågs ingen skillnad i HR-QoL.

Sammanfattningsvis är förekomsten av HAE i Sverige 1,54/100 000. Mittvärdet för åldern för debut av symptom var 12 år. Vuxna kvinnor har dubbelt så många attacker som män, och vuxna har också dubbelt så många attacker som barn. C1inhibitorkoncentrat har mycket god effekt vid akuta anfall. HAE har en påverkan på HR-QoL. Barn har bättre HR-QoL än vuxna. AE-QoL är ett mer sjukdomsspecifikt instrument än EQ-5D-5L och RAND-36, men det fångar inte smärtkomponenten som de andra gör. Patienter med hög sjukdomsaktivitet behöver ändra behandling för att få bättre HR-QoL. 


\section{List of Studies}

This thesis is based on the following studies, referred to by their Roman numerals

I. Hereditary Angioedema in Swedish Adults: Report From the National Cohort.

Patrik Nordenfelt, Mats Nilsson, Janne Björkander, Lotus Mallbris, Anders Lindfors, Carl-Fredrik Wahlgren.

Acta Derm Venereol. (2016) 96, 540-545

II. Swedish children with hereditary angioedema report good overall health and quality of life despite symptoms.

Anders Nygren, Patrik Nordenfelt, Anders Lindfors, Lotus Mallbris, Janne Björkander, Carl-Fredrik Wahlgren.

Acta Paediatr. (2016) 105, 529-534

III. Quantifying the burden of disease and perceived health state in patients with hereditary angioedema in Sweden.

Patrik Nordenfelt, Simon Dawson, Carl-Fredrik Wahlgren, Anders Lindfors, Lotus Mallbris, Janne Björkander.

Allergy Asthma Proc. (2014) 35, 185-190

IV. Health-related quality of life in relation to disease activity in adults with hereditary angioedema in Sweden.

Patrik Nordenfelt, Mats Nilsson, Anders Lindfors, Carl-Fredrik Wahlgren, Janne Björkander.

Allergy Asthma Proc. (2017) 38, 1-9 


\section{Abbreviations}

AAE

AAS

AAS28

ACE

ACE-inhibitor

AE

AE-QoL

$\mathrm{B}_{1}$-receptor

$\mathrm{B}_{2}$-receptor

C1

C1-INH

C1q

C1r

C1s

C4

ELISA

$\varepsilon$-ACA

EQ-5D

EQ-5D-5L

EQ5D attack

EQ5D today

EQ-VAS

FXII

FXIIa

GPCR

HAE

HAE type I
Acquired Angioedema

Angioedema Activity Score

Angioedema Activity Score 28 days

Angiotensin Converting Enzyme

Angiotensin Converting Enzyme inhibitor

Angioedema

Angioedema Quality of Life

Bradykinin receptor 1

Bradykinin receptor 2

Complement factor 1

C1 Esterase Inhibitor

q-subunit of Complement factor 1

r-subunit of Complement factor 1

s-subunit of Complement factor 1

Complement factor 4

Enzyme-Linked ImmunoSorbent Assay

Epsilon-aminocaproic acid

EuroQoL 5 Dimensions either 3 Level or 5 Level

EuroQol 5 Dimension 5 Levels

EQ-5D- 5L during an attack

EQ-5D-5Lbetween attacks

EuroQoL Visual Analog Scale

Factor XII of the contact- and coagulation system

Activated factor XII

$\mathrm{G}$ protein-coupled receptors

Hereditary Angioedema

Hereditary Angioedema type I, low amount of C1-INH 
HAE type II

HAE type III

HAE-nC1INH

HMWK or HK

HR-QoL

HSP 90

IRT

LK

NO

NSAID

QoL

RAND-36

PA

pdC1INH

$\mathrm{RC}$

rhC1INH

RP

RV

SD

SERPING1

Sweha

Sweha-Reg

VAS

WAO

WHO
Hereditary Angioedema type II, normal or high amount of faulty functioning $\mathrm{C} 1-\mathrm{INH}$

Hereditary Angioedema type III, normal C1-INH, also called HAE-nC1INH

Hereditary Angioedema normal C1-Inhibitor also called HAE type III

High Molecular Weight Kininogen

Health-Related Quality of Life

Heat Shock Protein 90

Individual Replacement Therapy

Low molecular weight Kininogen

Nitric Oxide

Non-Steroidal Anti-inflammatory Drugs

Quality of Life

RAND Corporation Short Form-36

Percent Agreement

Plasma-derived C1-INH concentrate

Relative Concentration, showing a change in concentration of answers between baseline and follow-up

Recombinant human C1-INH concentrate

Relative Position, showing a change between baseline and follow-up

Relative Rank Variation, showing a change in rank due to heterogeneous change among the patients

Standard Deviation

Serine/cysteine proteinase inhibitor clade G member 1 The gene responsible for $\mathrm{C} 1-\mathrm{INH}$

Swedish network of HAE-physician

The registry of Swedish patients with HAE type I/II

Visual Analog Scale

World Allergy Organization

World Health Organization 


\section{Introduction}

\section{History of hereditary angioedema}

Hereditary angioedema (HAE) is a rare disease with a prevalence of around 1/50 000 (1-3). Patients with angioedema, hereditary or not, have been described for several hundreds of years. One of the first descriptions of angioedema was made by Donati, who reported a young male who had a swollen lip after ingesting an egg, and proposed that an allergic reaction to egg might explain the reaction (4). A later report of swelling, presumably angioedema, was made by Franz Anton Mai in a book published in 1777, where he described a man waking up with swollen eyelids and lips; later that day the swelling also affected the larynx (5). In 1876, a British dermatologist, John Laws Milton (1820-1898), described a case of probable angioedema. He observed a patient who had "giant urticaria" on her face obscuring both eyes (6). The most well-known, early, and complete description of angioedema was made by the German physician Heinrich Quincke in 1882 (7). He was the first to report a series of patients with swellings, some of whom probably had HAE. Heinrich Quincke's student Eugen Dinkelacker also presented 14 patients with angioedema in his doctoral thesis. These patients were probably also included by Heinrich Quincke in his article (7), and in several countries, angioedema is thus often described as Quincke's oedema. Another name for angioedema often used earlier is angioneurotic oedema, a term proposed by Paul Strübing in 1885 because of a proposed mechanism of faulty nervous regulation of the vascular wall, causing an extravasation of fluid and oedema (8).

HAE was described in detail in 1888 by Sir William Osler, who recorded five generations in a family with recurrent angioedema. He described patients who had recurrent local swellings in different parts of the body, gastrointestinal disturbances and a hereditary disposition. He also stated that one died from asphyxiation (9). A recent comprehensive article on the history of AE and HAE was produced by Reshef et al. in 2016 (10).

The biochemical mechanism behind HAE was unknown for many years until the beginning of the 1960s. Irwin Lepow in 1961 identified an inhibitor of C1, the first component of the complement system, that he called C1 esterase inhibitor (C1-INH) (11). During 1963 and 1964, Virginia Donaldson and Richard Evans reported that patients with HAE had low levels of C1-INH $(12,13)$. Fred Rosen et al. discovered in 1965 that some patients with HAE have normal or even elevated levels of C1-INH but that the enzyme is not functioning. They called this new type of HAE type II, because it differed from the type with low C1-INH levels, which became known as type I (14). The gene SERPING1, responsible for the enzyme C1-INH, was first fully described in 1986 by Bock et al. (15). The mediator of the oedema in HAE was unknown until Allen Kaplan and co-workers discovered in 1983 that it was probably a kinin from the contact system (16). In the late 1990s, Nussberger et al. found that the main mediator of the angioedema in HAE was bradykinin (17). In the same year, 2000, Bork et al. and Binkley et al. independently published studies on a previously unknown form of HAE called HAE 
type III, also called HAE with normal C1-INH (HAE-nC1INH). This type of HAE is more common among females $(18,19)$. In 2006, it was revealed that some patients with HAE-nC1INH also have a mutation on the gene for FXII (20).

\section{Pathophysiology and classification of HAE}

The formation of angioedema in HAE is due to leakage of fluid from vessels in the subcutaneous tissue or mucus membrane mediated by bradykinin (21). Bradykinin mediate not only angioedema but has been shown to decrease blood pressure and in healthy humans it maintains normal blood pressure by counteracting Angiotensin II (22). It has also been implied in protecting against oxidative stress and from progression in diabetic nephropathy (23). Bradykinin mediates its effect via the two bradykinin receptors, the bradykinin receptor $1\left(B_{1}\right)$ and the bradykinin receptor $2\left(B_{2}\right)(24) . B_{1}$ is an inducible receptor, induced by inflammation and injury, and $\mathrm{B}_{2}$ is a constitutional receptor; both are $\mathrm{G}$ protein-coupled receptors (GPCR) (24). After activation of $\mathrm{B}_{1}$ and/or $\mathrm{B}_{2}$ cytosolic phospholipase A2 translocate to the cell membrane and $\mathrm{Ca}^{2+}$ increases intracellular secondary messenger as nitric oxide (NO), endothelium-derived hyperpolarizing factor, prostaglandins, and epoxyeicosatrienoic acids. These secondary messengers then increase natriuresis, and vasodilation, and lower oxidative stress, and increase fibrinolysis $(23,25)$. Under normal situations most of these effects are proposed to be mediated by the $B_{2}$ receptor, but in pathological situation as in inflammation the $B_{1}$-receptor might also be responsible for these effects (25). Icatibant is a $B_{2}$-antagonist and has an effect in HAE, implying that a main effect of the bradykinin in HAE is mediated by the $\mathrm{B}_{2^{-}}$ receptor (26). Bossi et al. revealed, however, that the $\mathrm{B}_{1}$-receptor could also be involved in $\operatorname{HAE}(27)$.

The extravasation of fluids that causes the oedema in tissue is due to that the tight junctions between the cells in the endothelium uncouples letting fluids passing between the cells (28). The uncoupling of tight junctions looks like pulling down a zipper $(29,30)$. Tight junctions are mediated in endothelial cells by vascular endothelial cadherins (VEC) (30). $\mathrm{B}_{2}$ receptor activation leads to phosphorylation of VEC that disrupts the tight junction between the endothelial cells and fluids can extravasate (31).

The contact system has to be activated to form bradykinin, and is activated by negatively-charged surfaces. The coagulation factor XII must first be activated to factor XIIa. Factor XIIa converts prekallikrein to kallikrein, which cleaves the high molecular weight kininogen (HMWK) to bradykinin (Figure 1) (32). Factor XII can in small quantities activate itself (autoactivation), and this activation is enhanced by negativelycharged surfaces and substances like heparin and endotoxin (32). Heat shock protein 90 (hsp90) can also activate kallikrein without involving factor XII (33). 


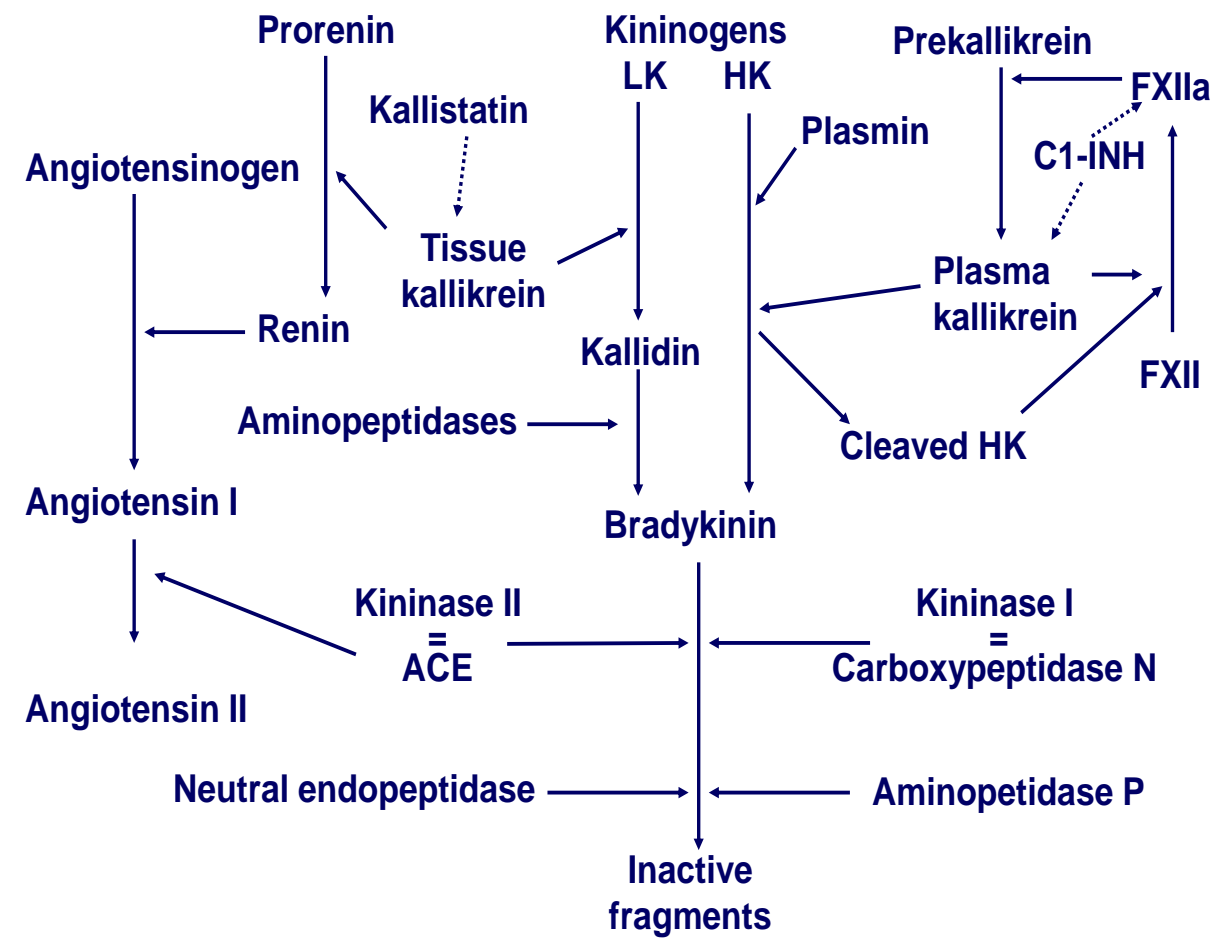

Figure 1. Formation of bradykinin. Reprinted with permission from Massimo Cugno. ACE=Angiotensin Converting Enzyme, HK= High molecular Kininogen, LK=Low molecular Kininogen 
To stop the formation of bradykinin, the enzymes that lead to its formation must be controlled, and the main inhibitor enzyme is C1-INH. C1-INH inhibits both factor XII and kallikrein (33). C1-INH is termed an 'inhibitor' because of its ability to inhibit the first complement factor $(\mathrm{C} 1)$ and in particular $\mathrm{C} 1 \mathrm{r}$ and $\mathrm{C} 1 \mathrm{~s}$ of the $\mathrm{C} 1$ in the complement system (11). In HAE type I and II, patients lack functional C1-INH $(12,14)$. The diminished capacity of inhibition of $\mathrm{C} 1 \mathrm{r}$ and $\mathrm{C} 1 \mathrm{~s}$ in patients with $\mathrm{HAE}$ type $\mathrm{I} / \mathrm{II}$ increases the degradation of complement factor 4 (C4) in particular during attacks. This can be used to diagnose HAE (34). The gene coding for C1-INH is called SERPING1, and is located at 11q12.1 (15). C1-INH inhibits the protease by making a covalent binding to the active site of the protease and making a complex of protease and C1-INH which is cleared from circulation (35). More than 500 mutations of the SERPING1 are known so far (36).

Different forms of angioedema mediated by bradykinin include HAE type I, in which there are low levels of $\mathrm{C} 1-\mathrm{INH}$, and type II, with a normal or high level of non-functional C1-INH. Both these forms are autosomal inherited. Up to $25 \%$ of patients with HAE type I/II are new mutations, and have therefore not inherited their disease, but can pass it on to their children $(34,37)$. As mentioned earlier, HAE-nC1INH has also been described $(18,19)$. This form has in some cases been associated with a mutation on the gene to factor XII $(20,38)$, and is more common in females, which might be due to the influence of oestrogen (18). Bradykinin is also the mediator in acquired angioedema (AAE), a rare disease, which results from an acquired deficiency of C1-INH. AAE is often due to lymphoproliferative diseases or an autoantibody against C1-INH (39). Still another type of angioedema occurs in patients treated with angiotensin-converting enzyme inhibitor (ACE-inhibitor), due to a decreased ability to degrade bradykinin. ACE-inhibitor-induced angioedema can be treated with icatibant (Figure 1) (40).

In a general perspective, HAE and AAE are rare. The most common form of angioedema is known as histaminergic as it induced by histamine and responds to glucocorticoids, H1-receptor antagonists, and epinephrine (41).

\section{Epidemiology}

As mentioned earlier, HAE is a rare disease with a proposed prevalence of $1 / 50,000$ (42). As HAE type I/II is autosomal dominant inherited, it is as common in males as in females. In Spain, Roche et al. reported a prevalence of 1.09/100,000, in Denmark, Bygum has shown a prevalence of 1.41/100,000 in 2009, and in Italy, Zanichelli et al. found a prevalence of 1.54/100,000 in 2015 (1-3). These data on prevalence are only from Europe, and comparable data on prevalence outside Europe have to my knowledge not been shown elsewhere. For example, Lei et al. in Taiwan, Iwamoto et al. in Japan and Grumach et al. in Brazil have not identified enough patients in their studies to calculate a reliable prevalence (43-45). Earlier, when treatment was not available, about one third of patients died from asphyxiation (46). Of patients with HAE, 80-85\% have type I and the rest, about $15-20 \%$, have type II (34). 


\section{Clinical manifestations}

The main clinical finding in HAE is attacks of angioedema. Angioedema can appear in the skin of almost every part of the body, although angioedema in HAE usually appears where the skin meets mucous membrane; e.g. in the face and mouth and in the genitals. The swelling can appear in the mucous membrane of the larynx, where if left untreated it can lead to death by asphyxiation. In the intestine, angioedema can lead to severe colic pain, diarrhoea and vomiting. HAE attacks in the intestine can also lead to hypotension due to massive leakage of fluid into the abdomen causing ascites and hypovolemia. Intestinal attacks of HAE can be mistaken for other acute abdominal diseases, such as appendicitis and peritonitis, and several patients with HAE have gone through unnecessary surgical interventions. Angioedema in other parts of body can lead to swollen hands or feet. The swellings are normally not red (47-51). The angioedema in HAE is not believed to be pruritic, while histaminergic angioedema often can be pruritic $(42,52)$. Left untreated, angioedema in HAE often lasts for up to three to five days $(47,53,54)$. There are also a few reports of patients with HAE having recurrent neurological symptoms that have been proposed to be due to cerebral swelling $(2,55)$.

The severity of the disease varies between patients. Many patients have several attacks monthly or yearly, while other patients may have one or no annual attack. The location of the mutation in the SERPING1 gene seldom correlates with the severity of the disease, and this is shown by the fact that the severity of the disease varies between family members, even though the mutation is the same (47). About $10 \%$ of those with biochemical findings in line with HAE type I/II are asymptomatic, and have been diagnosed because of a relative having HAE (1).

Most patients with HAE start having attacks in their youth. HAE rarely starts after the age of 30, and also rarely starts before the age of one year. According to Bork et al, about one third of patients start to have attacks before the age of five and one third after the age of 15 and the rest between the age of five and 15. (47). Those who start having attacks earlier in life, often have more attacks than those whose attacks start later (47).

In up to two thirds of the attacks, prodromal symptoms have been described, such as unusual fatigue, rash, muscle aches, abdominal pain, and nausea (56). The classical prodromal finding in HAE, which is almost pathognomonic but also found in rheumatic fever, is the skin rash called erythema marginatum, resembling chicken wire (57-59). Reports of how many patients with HAE have experienced erythema marginatum vary; in Denmark between a percentage of 56-58 has been reported and in Hungary a report states that $42 \%$ of patients with HAE have had this symptom $(2,60,61)$.

Triggers of HAE attacks can be trauma, even iatrogenic such as that occurring in dental or surgical procedures, psychological stress, fatigue, infections, alcohol, and the menstrual cycle or unknown causes. Medication such as ACE-inhibitors and oestrogen-containing contraceptives also worsen the course of the disease $(34,48,62,63)$.

Bradykinin-induced angioedema that starts after the age of 30 , in patients with no relatives with HAE, is most likely caused by medication with ACE-inhibitors, and rarely by AAE, which is often associated with a lymphoproliferative disease $(34,64,65)$. 
HAE type I and II are equally common in both females and males, but females often have a more severe disease, with more frequent attacks from puberty to menopause. During pregnancy, the attack rate in HAE often increases. Birth-control medications that contain oestrogens usually worsen the disease for females $(47,63,66)$.

\section{Diagnosis of HAE type I/II}

A screening test can be performed to measure complement $\mathrm{C} 4$, which is low in probably all patients with HAE type I/II during an attack. Between attacks, up to 5\% of patients have a normal level of $\mathrm{C} 4$, and thus the HAE-diagnosis can be missed by measuring $\mathrm{C} 4$ alone $(34,67)$. To diagnose HAE type I/II, one must measure both the antigenic level and the function of C1-INH. To measure the function of C1-INH, two methods are available, namely chromogenic and Enzyme-Linked ImmunoSorbent Assay (ELISA) tests. To be diagnosed with HAE type I, the patients must have an antigenic level of $\mathrm{C} 1$ INH of less than 50\%. If the patient's antigenic level of HAE is normal or high, as in HAE type II, the functional level of C1-INH must be lower than $50 \%$ measured with chromogenic assay or less than $84 \%$ measured with an ELISA assay. The measurement must be done after the age of one year, as the level of $\mathrm{C} 1$-INH before that age is uncertain. The blood test must also be carried out twice, with at least a month in between, to exclude laboratory mistakes (Figure 2) $(34,68)$.

If the patient does not have a relative with $\mathrm{HAE}$, and the age of onset is over 30 years, it is recommended that $\mathrm{Clq}$ should also be measured; if this is low, it can indicate AAE instead of HAE type I/II (Figure 2) $(34,69)$.

As mentioned earlier, some patients with recurrent angioedema and a family history of angioedema have normal level $\mathrm{C} 1-\mathrm{INH}$, and in this case the disease is known as HAE type III or HAE-nC1INH. Some of these patients have a mutation on the gene that expresses factor XII. For a diagnosis of HAE-nC1, the patient must have a family history of HAE and be unresponsive to medication used in histaminergic angioedema (Figure 2) $(18,20,34)$.

Diagnosing HAE with a blood test by measuring C1-INH before the age of one year, is uncertain. Testing of the SERPING1 gene responsible for C1-INH can be done, but in up to $10 \%$ of patients with HAE type I/II no mutation can be found (34). The recommendation is therefore that in children, one must confirm the diagnosis with a test after one year of age (34). Prenatal diagnosis by testing the SERPING1 gene is also possible but not common (34). 


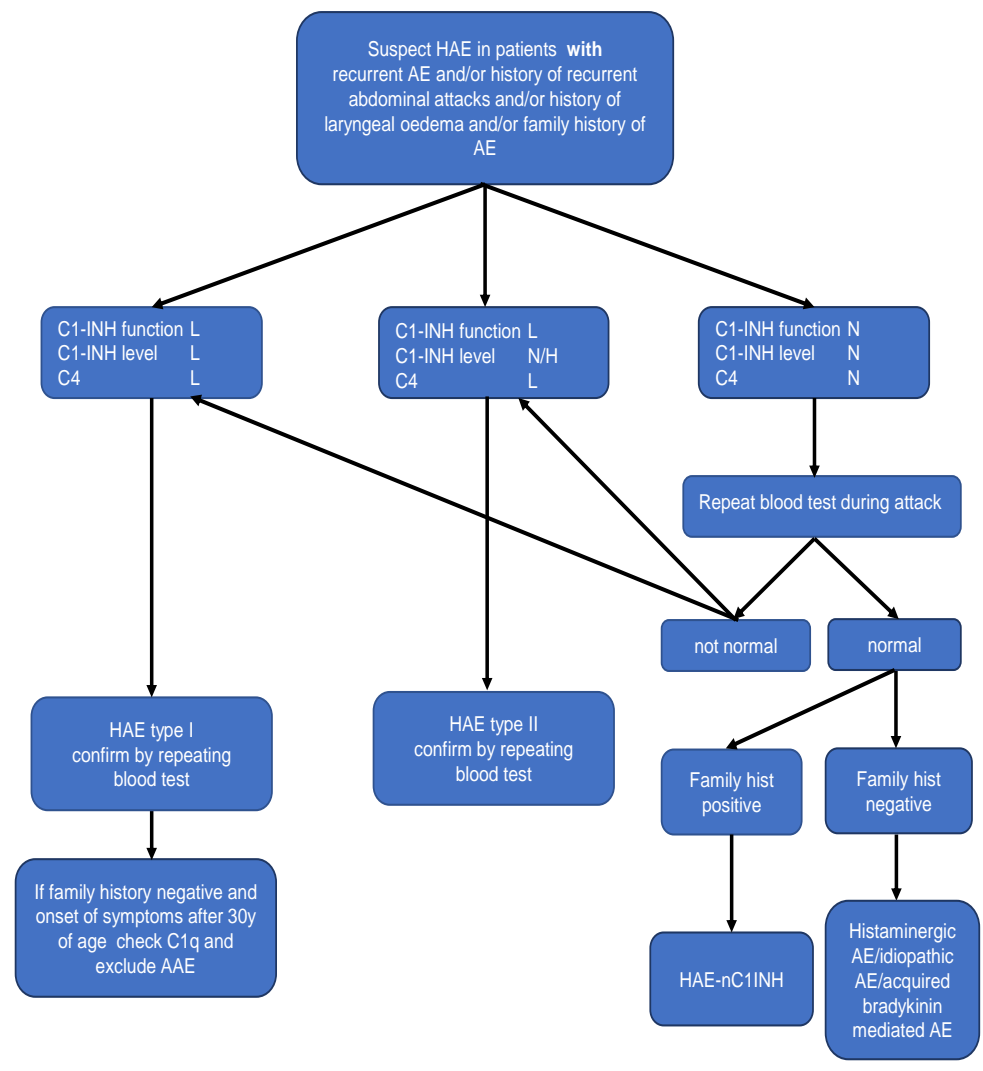

Figure 2. Algorithm for diagnosing HAE adopted after World Allergy Organization guideline for management of $\mathrm{HAE}$ by Craig et al. $\mathrm{AE}=$ angioedema, $\mathrm{AAE}=$ Acquired angioedema, $\mathrm{HAE}-\mathrm{nC} 1 \mathrm{INH}=\mathrm{HAE}$ with normal $\mathrm{C} 1$ inhibitor, $\mathrm{H}=$ high, $\mathrm{L}=$ low, $\mathrm{N}=$ normal 


\section{Treatment}

The first effective treatments for HAE that prevented attacks arrived in the 1960s and 1970s, with the synthesised androgens and the attenuated androgens, such as danazol and stanozolol (70). The use of androgens is nowadays not as strongly recommended as it was because other treatments are now available and because androgens have undesirable side effects (34). The anti-fibrinolytic agent epsilon-aminocaproic acid ( $\varepsilon$-ACA) was shown by Nilsson et al. to be useful in HAE, and Blohmé et al. showed that tranexamic acid could also be used $(71,72)$. Today tranexamic acid and $\varepsilon$-ACA are not highly recommended because they have been shown to be less effective, but as tranexamic acid is cheap and often well tolerated, many patients with HAE have tried it $(34,73)$. In the 1960 s, fresh frozen plasma was used to treat attacks of HAE; it is nowadays not recommended, but in countries without other treatments it has been an option $(34,74)$. Instead of fresh frozen plasma, plasma-derived C1-INH concentrates (pdC1INH) are now widely used and recommended in attacks (34). In 1973, Brackertz and Küppers first described the use of pdC1INH in patients with HAE (75). The first commerciallyavailable product with pdC1INH was Berinert®, licensed in Germany in 1979. Another pdC1INH product now available is Cinryze ${ }^{\circledR}$, which has been studied by Zuraw et al. (76). A recombinant human $\mathrm{C} 1$-INH concentrate (rhC1INH) has been developed called Ruconest@ (conestat alfa) $(77,78)$. In recent years, more treatments have been available, such as the bradykinin receptor inhibitor Firazyr ${ }^{\circledR}$ (icatibant), and a kallikrein inhibitor, Kalbitor ${ }^{\circledR}$ (ecallantide) $(79,80)$.

All types of attacks are recommended to be considered for treatment, but attacks in the larynx, tongue, lips and throat that affects the airways must be treated, and attacks in the abdomen often demand treatment due to the severe pain they cause. It is also recommended that the patient has access always to treatment for two attacks $(34,73)$.

For acute attacks, pdC1INH, rhC1INH, icatibant and/or ecallantide can be used (34). Only pdC1INH is approved for children and during pregnancy (34). PdC1INH can so far only be recommended to be given intravenously, though subcutaneous formulas are on the way (81). Many patients have been trained to use pdC1INH and can inject themselves, which is known as home therapy (82). PdC1INH can be given on demand; that is, patients take the drug when an attack occurs. It can also be taken as individual replacement therapy (IRT); meaning that the patient takes the drug as soon they think they are going to have an attack (83). The dosage differs between the two main products: Berinert is dosed at $20 \mathrm{IU} / \mathrm{kg}$ bodyweight and Cinryze is dosed at $1000 \mathrm{IU}$ irrespective of bodyweight $(84,85)$. The dosage of $\mathrm{rhC} 1 \mathrm{INH}$ conestat alfa is $50 \mathrm{IU} / \mathrm{kg}$ bodyweight up to a weight of $84 \mathrm{~kg}$, after which the dose is $4200 \mathrm{IU}$, and conestat alfa, extracted from the breast milk of transgenic rabbits that express human rhC1INH, is also given intravenously $(86,87)$. Due to different glycosylation, rhC1INH has a shorter half-life than pdC1INH, which is why the dosage is higher with rhC1INH (88). The risk of transmitting disease with pdC1INH is low because the product is treated with pasteurization, hydrophobic interaction chromatography, and virus filtration, but the risk is perhaps even lower with the rhC1INH, as it is not from a human blood product (76, 88-90). Icatibant is a bradykinin receptor 2 antagonist that has been shown effective in treating HAE attacks and is given as a subcutaneous injection of $30 \mathrm{mg}$ (79). Icatibant is a $10-$ 
amino acid peptide that resembles bradykinin, but instead of working as an agonist of the bradykinin receptor 2 it works as an antagonist (79). Another option for treating acute attacks is a kallikrein inhibitor called ecallantide. Ecallantide is given as a subcutaneous injection of $30 \mathrm{mg}$. The drug is a recombinant small protein that inhibits plasma kallikrein $(91,92)$. Ecallantide is not approved in Europe in 2017 (93).

Treatment of HAE can also be aimed at reducing or abolishing the attacks by prophylactic use. Prophylaxis can be used for both short-term and long-term purposes $(34,73)$. Short-term prophylaxis can be used before known triggers such as surgery, or anticipated stressors such as examinations or weddings (34). Before dental and surgical procedures that affect the mouth, such as dental work/surgery, intubation, endoscopy or bronchoscopy, prophylaxis is recommended (34). The most common short-term prophylactic is pdC1INH (34). When pdC1INH was not readily available, attenuated androgen was often used for short-term prophylaxis but nowadays pdC1INH is more strongly recommended because it is perceived to have a higher efficacy $(34,46)$.

Patients with recurrent attacks can be eligible for long-term prophylaxis, and according to Cicardi et al, those with attacks once a month should be eligible, but in the World Allergy organization (WAO) guidelines, no specific attack rate is mentioned; instead, the physician has to consider the impact the disease has on the patient before deciding whether to initiate long-term prophylaxis or not $(34,73)$. For long-term prophylaxis, previously only tranexamic acid and androgens were used (46). Tranexamic acid works possibly by inhibiting plasminogen from converting to plasmin, so that the plasmin cannot then cleave high molecular kininogen to bradykinin (94). Androgens seem to normalise the level of functional C1-INH (95). Nowadays tranexamic acid is not recommended because of its lack of efficacy (34). Tranexamic acid is still often tried, as it is cheap and often having few severe side effects (34). Androgens are still considered to be effective, but concerns about side effects have been raised $(34,73)$. Side effects are, among others: alteration in blood lipids, high blood pressure, raised liver enzyme levels, weight gain, and increased risk of cardiovascular disease. Females on androgens can be masculinised, experiencing hoarse voice, hirsutism and increased muscle mass $(34,73)$. Androgens used in HAE are stanozolol, danazol and oxandrolone $(96,97)$. Androgens are not recommended to be used in children, during pregnancy or in females intending to become pregnant (34). For long-term prophylaxis, pdC1INH can be used; it is safe and has been effective in studies $(34,98)$.

\section{Health-related quality of life}

\section{Health}

HAE is known to affect health-related quality of life (HR-QoL) (99). To measure HRQoL, one must consider what health is. According to the World Health Organization (WHO), in 1948: "Health is a state of complete physical, mental and social well-being and not merely the absence of disease or infirmity" (100). This definition is holistic in that it includes not only physical but also mental and social well-being, and it has been criticised by among Huber et al. as being too strict and regarding too many people as not healthy (101). Instead Lennart Nordenfelt has proposed that a human being has full 
health if he/she has the possibility to realise all his/her vital goals in any given situation (102). This definition does not exclude a person from being regarded as fully healthy even if that person has been diagnosed with a disease, so long the disease does not hinder the person from fulfilling his/her goals.

\section{Health-related quality of life}

As we have mentioned the health aspect of HR-QoL, quality of life (QoL) must also be mentioned. QoL reflects different areas of a patient's life, such as economic situation, work, religion, social life, and physical health (103). QoL can be divided into global, component, focused, and combination definitions. In the global definition, the patient's happiness or satisfaction is characterised. The component definition specifies certain aspects and can contribute to the global definition. Component definition usually represents the maintenance of dignity, emotional well-being and freedom of choice. The focused definition usually refers to health/functional ability, as does the HR-QoL (103).

To evaluate the effects an intervention such as a new medication has on a patient or the impact a disease has on a patient, HR-QoL measurements are often used. HR-QoL measurements are used in clinical medicine instead of QoL measurements, because QoL includes aspects that are not always dependent on the person's health, such as economic situation, work, and religion, while by measuring HR-QoL, these aspects are excluded (104, 105). HR-QoL measures aspects of the patient's life that are more specific to health, such as how disease and symptoms affect well-being and the ability to function in daily life $(103,106)$.

To measure HR-QoL, different instruments are used. The instruments can be diseasespecific or general. General instruments are often used when no disease-specific instrument is available, or if one wants to compare the impact of different diseases on HRQoL. Disease-specific instruments can highlight aspects of a disease that generic instruments cannot.

Examples of generic instruments are the EuroQoL-5 Dimension (EQ-5D), Short Form36 (SF-36) and RAND Corporation Short Form-36 (RAND-36) questionnaires, while examples of disease-specific instruments for use in HAE are the Angioedema Quality of Life (AE-QoL) and Hereditary Angioedema Quality of life (HAE-QoL) questionnaires (107-111).

To further assess the disease burden of HAE, an instrument measuring the disease activity for various angioedema diseases can be used. Recently Weller et al. have developed the Angioedema Activity Score (AAS) (112).

\section{HR-QoL and HAE}

There have been an increasing number of studies recently showing that HAE has an impact on HR-QoL. In the USA, Lumry et al. used the SF-36 in 2010 in patients with HAE, in Brazil in 2013 the SF-36 was used by Gomid et al, and in Canada in 2017, the SF-36 was also used by Jindal et al. $(99,113,114)$. In other HR-QoL studies of HAE, researchers, such as Aygören-Pürsün et al. have been used the EQ-5D (115). The AE- 
QoL has been used in a study about the improvements shown in HR-QoL when using subcutaneously injected pdC1INH (116).

A few studies have been carried out in the past about how HAE affects children, but recently more studies have been done about the impact of the disease on them, such as those by Read et al, and Farkas et al. Both studies showed that HAE affects children's lives $(117,118)$.

\section{HAE in Sweden prior to these studies}

In 1964, Nilsson et al, presented nine cases of periodic diseases, including HAE, in Sweden and in 1972 Blohmé et al., described three Swedish families with HAE (119, 120). Treatments with antifibrinolytics were also presented from Sweden in 1966 and $1972(71,72)$.

No further studies have been carried out since then on patients with HAE in Sweden, and there is thus a significant lack of data on the situation for patients in Sweden. This thesis aims to address this shortage of data. 


\section{Aim}

1. To explore the prevalence of HAE in Sweden.

2. To investigate clinical manifestations and treatments in adults and children with HAE in Sweden.

3. To assess health and HR-QoL in adults and children with HAE in Sweden.

4. To measure the impact of HAE on adults by using both general and disease-specific HR-QoL instruments in relation to disease activity.

5. To compare the outcomes of the different HR-QoL instruments. 


\section{Method}

\section{Patient recruitment}

A collaboration called Sweha began in 2007 between a number of physicians in Sweden who were interested and had experience in HAE (121). The physicians came from centres that treated patients with HAE, such as those in Stockholm, Gothenburg, Jönköping, and Lund, and a register called the Sweha-Reg for patients with HAE was later launched. To be included in the registry, the patients had to agree to participate and to have a physician's diagnosis of HAE. The diagnosis of HAE included a laboratory confirmation of either HAE type I or II with antigenic concentrations of C1INH $<50 \%$ of normal values and/or functional levels of $\mathrm{C} 1$ inhibitor $<50 \%$ (chromogenic assay) or $<84 \%$ (ELISA assay) of normal values obtained after the first year of life (68). We tried to locate all patients in Sweden diagnosed with HAE, with the help of the Swedish Patient Organization (PIO) and by contacting the two special laboratories for complement deficiency analysis and all Swedish departments of internal medicine, otorhinolaryngology, allergology, dermatology and paediatrics. A total of 629 clinical units were asked, of whom 239 responded. Two hundred denied having knowledge of any patient with HAE. After informed consent was obtained, the patients were recruited and consecutively entered the registry, which now includes patients entered between 2007 and 2016. Patients with HAE-nC1INH are not included in the registry.

All four studies in this thesis (I-IV) include only patients with HAE type I/II. In study I, we focused on adults $(\geq 18$ years of age), and in study II, only children (0-17 years of age) were included. Patients for studies I and II were included between 2007 and 2011. Study III included both children and adults, and study IV included only patients from 18 years of age. Inclusion for study III was during 2011 and for study IV, patients were included in 2016.

\section{Questionnaires}

\section{Studies I and II}

All patients who were asked to participate, initially answered a written questionnaire, and then to participate in a telephone interview. There was one questionnaire for children and one for adults. The patients (or the parents of children) who answered and returned the written questionnaire later had a one-hour structured telephone interview performed by the same investigator (PN). Questionnaires covered demographic data, family history, sexual health, sick leave and detailed clinical information on HAE. Questions about the patients' QoL on a seven-grad scale and health assessment on a five-grade scale were also included in the questionnaire. See appendix. 


\section{Study III}

In study III, the EuroQol 5 Dimension, 5 Level (EQ-5D-5L) instrument was used. Patients completed two EQ-5D-5L questionnaires; one to describe their current HR-QoL (EQ5D today) and one retrospective, to estimate the patients' HR-QoL during their most recent HAE attack (EQ5D attack). The EQ-5D-5L is a generic instrument describing HR-QoL in five dimensions: mobility, self-care, usual activities, pain/discomfort, and anxiety/depression. Each dimension has five response categories, ranging from no problems to extreme problems. EQ-5D with 3 levels do also exist that has instead of five three response categories, here used only EQ-5D-5L. The patients were requested to complete the instrument themselves, and the respondents also rated their overall health state on the day of completion on a $0-100$, (where 100 is best), hashmarked, vertical visual analogue scale (EQ-VAS). The five graded responses of the EQ5D-5L were transformed into utility values ranging from 1 (full health) to 0 (equivalent to death), with even a score below zero being possible. The utility values are obtained by studies in the general population asking people how they value different kind of hypothetical health states. As there were no Swedish utility values available using the standard method of obtaining utility values in EQ-5D, we used the English ones, as they were widely used $(107,122,123)$. The Swedish values that exist are obtained by asking people how they value their own health and therefore not comparable with other EQ-5D values (124).

The patients were asked to complete a questionnaire about demographics such as age and sex, absenteeism from work or school and other variables, such as attack location and frequency.

They were also asked about attack severity, as defined by the patient on a three-grade scale:

Mild: Symptoms were noted by the patient but they did not impact activities of daily living. For example, the patient's hand was swollen but the patient could still hold a pencil or grip a utensil.

Moderate: The patient felt the need to treat the symptoms during the attack or the patient's activities of daily living were affected. For example, if the patient's hands were swollen and the patient could not button the shirt, or the feet were swollen and wearing shoes was uncomfortable for the patient.

Severe: Treatment or intervention was necessary for the patient or he/she was unable to perform activities of daily living. For example, the throat was swollen and breathing was difficult, or the lips were swollen and eating was not possible. 


\section{Study IV}

In this study, we used the instruments EQ-5D-5L, RAND-36, AE-QoL, and AAS (107, 109, 110, 112). The EQ-5D-5L has been described above.

The RAND-36 is a generic instrument with 36 items (similar to the Short Form-36), both originally developed by the RAND Corporation, which include nine dimensions: physical function, role limitations due to physical health or short physical health, role limitations due to emotional problems or short emotional problems, energy/fatigue, emo-tional well-being, social functioning, pain, general health and health transition. Each dimension contains several items, from which an average score between 0 (worst) and 100 (best) was calculated. No general score is available (109).

The AE-QoL instrument has 17 items intended for patients with recurrent angioedema, for example HAE. The instrument measures the impairment recurrent angioedema has on the patients' HR-QoL. The items can be added to a total AE-QoL score and can be used to analyse four dimensions: functioning, fatigue/mood, fears/shame and nutrition. Both the total AE-QoL score and the score for each dimension varies between 0 (best) and 100 (worst) (110).

The AAS questionnaire is used to measure angioedema activity. The patients were asked to answer the questions in AAS for 28 consecutive days (AAS28). The questionnaire asked the patients to enter whether they had an attack of HAE, and estimate the length of the attack, the strength of their physical impairments, difficulties performing daily activities, impairments of appearance, and an overall assessment of the attack (112). The AAS28 score ranged from 0 to 420 (112). The score was categorized into four levels, no (0), low (1-25), moderate (26-75), and high (76-420). This four-graded scale was modified from the study that validated AAS (112).

A questionnaire regarding selected background variables, such as visits to hospital, acute treatments, prophylactic treatments and sick leave due to HAE was also obtained.

All patients first replied to the EQ-5D-5L, RAND-36 and AE-QoL, and returned these questionnaires. The patients then responded to the AAS28. To determine whether the patients' answers to the instruments changed over time, they were asked a second time to respond to the EQ-5D-5L, RAND-36, and AE-QoL after completing the AAS28 (Figure 3). 
Invited to participate from Sweha-Reg 133 adults, 71 females, 62 males, Type I $n=125$, Type II n=8
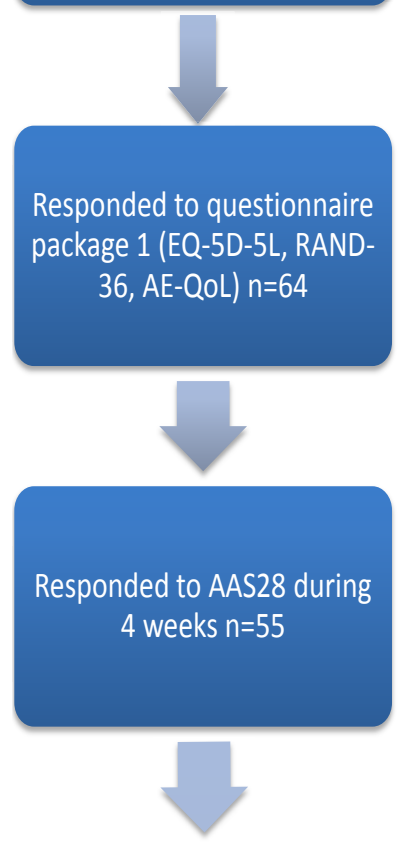

Responded to questionnaire package 2 (EQ-5D-5L, RAND36, AE-QoL, and questionnaire about sick leave and medication) $n=48$
Denied participation $n=9$ no response $n=60$

\section{Drop out $n=7$}

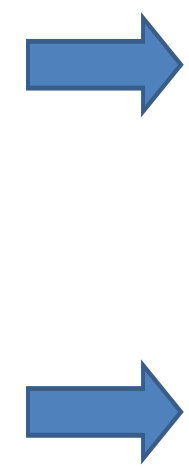

\section{Drop out $n=9$}

\section{Drop out n=7}

Figure 3. Flowchart of study IV. 


\section{Ethics}

Studies I and II were carried out simultaneously and therefore had the same approval from the Regional Ethics Committee in Stockholm/Karolinska Institutet (Dnr 2006/1467-31/2). The Swedish Data Inspection Board approved the collection of individual data into a computerised register.

Study III was approved by the Regional Ethics Committee in Stockholm/Karolinska Institutet (Dnr 2011/813-32).

Study IV was approved by the Regional Ethics Committee in Linköping/University of Linköping (Dnr 2015/442-31).

All studies conformed to the Helsinki declaration. All data were anonymised before the statistical analysis was performed.

\section{Statistics}

In studies I to IV, descriptive results were presented as numbers, percentages, means, medians, and ranges where appropriate. Since most of the data is paired ordered categorical data, we used statistical methods for this type of data. The Kruskal-Wallis test, The Fisher's Exact test, Wilcoxon Signed Rank test, the Mann-Whitney U test and the Student t-test were used where it was appropriate to analyse differences between groups. P-values $<0.05$ were considered to be statistically significant.

In studies III and IV, Spearman's Rank correlation was used.

In study IV, Spearman's Rank correlation was used for evaluating concordance between the dimensions of the instruments. We regarded correlation coefficients above 0.6 or below -0.6 as clinically associated in study IV. To analyse differences in response over time (baseline and after four weeks) on the questionnaires, we used Svensson's method for paired ordered categorical data. This method is described at http://avdic.se/svenssonsmethodenglish.html, where an Excel-macro for calculation can be downloaded. The main parameters estimated with this method are: Percent Agreement (PA), Relative Position (RP, showing a change in the position between baseline and follow-up), Relative Concentration (RC, showing a change in concentration of answers between baseline and follow-up) and Relative Rank Variation (RV, showing a change in rank due to heterogeneous change among the patients). If PA is near $100 \%$ and RP and/or RC close to zero, there are no differences in answers on the scale between baseline and follow-up (125-127). Dell Statistica (data analysis software system), version 13 was used for the statistical analysis in all studies. 


\section{Results}

\section{Response rate, demographics, HAE type and family history (studies I and II)}

In the first study, we had 142 patients with HAE registered in the database of the Sweha-Reg up to June 1, 2011, and we also had knowledge of four other patients, who clearly stated that they did not want to participate in the questionnaires, giving a total of 146 known patients with HAE in Sweden. This gives a calculated minimal HAE type I/II prevalence of 1.54/100,000 in Sweden. All counties in Sweden had patients with HAE. The patients' median age at entry of the study was 40 years, ranging between one and 87 years (Table I). Of the 142 patients in the Sweha-Reg, 133 (94\%) returned the written questionnaire and of those, 129 participated in the telephone interview, giving a complete response rate of $91 \%$.

Including the four patients who did not want to be entered in the Sweha-Reg, there were 136 patients with HAE type I and 10 patients with HAE type II. We could identify 39 families, with up to four members affected, 36 with type I and three with type II. One hundred and sixteen of the 133 respondents to the written questionnaire $(87 \%)$ were aware of at least one ancestor with HAE.

In study I, we presented the results for the 102 adults who answered the written questionnaire and the 99 adults who also participated in the telephone interview (Table I).

In study II, we identified 36 patients under the age of 18 in the Sweha-Reg, of whom 31 (86\%), 18 boys and 13 girls, answered the questionnaire (Table I). The five non-responders were aged between one and 17 years of age. A 17-year-old girl answered the questionnaire without the help of her parents, and the other questionnaires were answered by at least one parent and the child together $(n=16)$ or by at least one parent with no input from the child $(n=14)$. The telephone interview was answered by 29 of the 31 patients: 28 parents and the 17-year-old girl.

The median age of the child was nine years when the family responded to the written questionnaire, (range 1-17 years). HAE type I had 29 children, while only two had HAE type II. All children with HAE had a family history of HAE, 18 from their maternal side and 13 from their paternal side. Ten of the 29 telephone interviewed children, reported that at least one ancestor of the patient had died due to HAE. 
Table I. Number of subjects with HAE identified in Sweden, and numbers responding to the written patient questionnaire and the telephone interview by the physician.

\begin{tabular}{lccc} 
Base & All (F/ M) & $\begin{array}{c}\text { Children 0-17 yrs } \\
(\text { F/M })\end{array}$ & $\begin{array}{c}\text { Adults (18-) } \\
(\text { F/M })\end{array}$ \\
\hline Census & $146(71 / 75)$ & $36(16 / 20)$ & $110(55 / 55)$ \\
Patient questionnaire & $133(63 / 70)$ & $31(13 / 18)$ & $102(50 / 52)$ \\
$\begin{array}{l}\text { Physician's telephone } \\
\text { interview }\end{array}$ & $128(61 / 67)$ & $29(13 / 16)$ & $99(48 / 51)$ \\
\end{tabular}

\section{Age at onset and at diagnosis}

\section{Adults}

The median age at onset of symptoms was 12 years of age, (range $0-50$ years, $n=98$ ); for females, 13 years (range $1-50, n=48$ ) and for males 10.5 years (range $0-50, n=50$ ). The median age at diagnosis $(n=99)$ was 22 years (range 1-81); for females, 20.5 years (range 4-60, $\mathrm{n}=48$ ) and for males 22 years (range 1-81, $\mathrm{n}=51$ ). The median time duration to diagnosis for all with onset of symptoms before diagnosis $(n=91)$ was 10 years (range 0-67); for females, 6 years (range 0-42, $n=45$ ) and for males 14 years (range 0-67, n=46) years. Eight patients were biochemically diagnosed before the onset of symptoms.

\section{Children}

Of the 31 patients, 23 (74\%) had experienced HAE symptoms: 12 of the 18 boys and 11 of the 13 girls.

The median age at the onset of symptoms was four years, and the mean age was 4.6 years (range 0-10 years) with no significant difference between boys and girls (Figure 4). The median age of the eight children who were diagnosed with HAE but did not report any HAE symptoms was two and a half years (range 1-17). The median age at diagnosis was three years (range 1-9).

\section{Overall}

For all symptomatic patients with HAE, the median age of onset was 10 years of age, ranging from $0-50(n=121)$. For all, the median age of diagnosis was 18 years of age, ranging from $0-81$. The median time to diagnosis for all patients who were symptomatic before diagnosis was six years, ranging from 0-67 year $(n=106)$. 


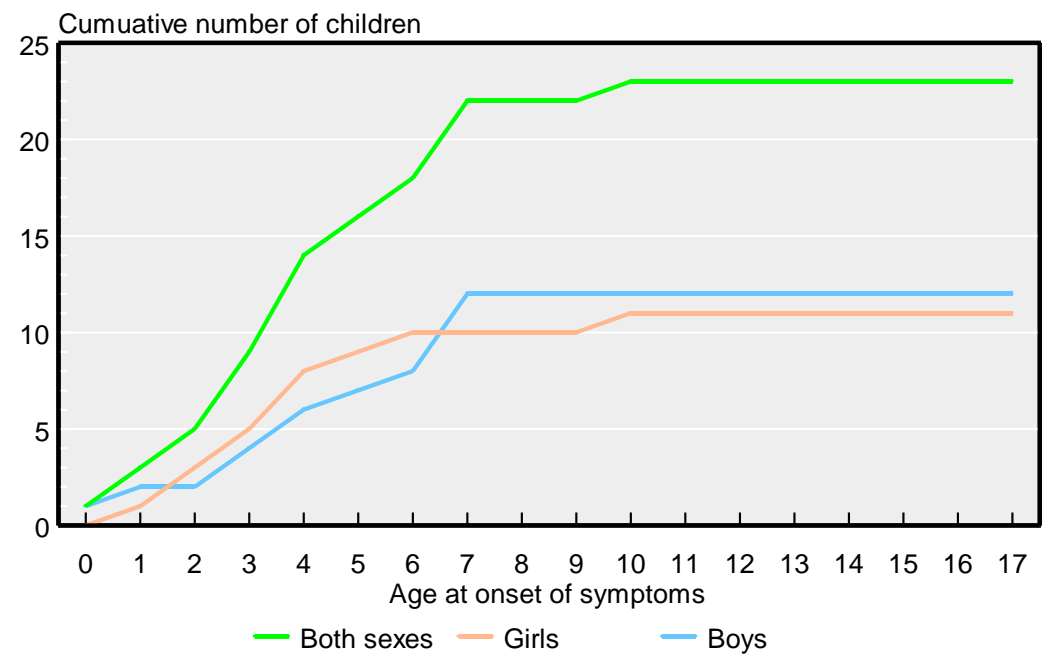

Figure 4. Distribution of children with HAE regarding onset of symptoms and age. Total number of patients $n=31$ ( 18 boys, 13 girls). Patients with onset $n=23$ ( 12 boys, 11 girls).

\section{Clinical manifestations}

\section{Adults}

When asked about attacks of angioedema during the previous year, 20 patients had no attacks and 80 had attacks $(n=100)$. Of those who had attacks, we received data on attack frequency from 76 patients, who had a median of 14 attacks; one female extreme outlier with 475 attacks was excluded. In the previous year, females had approximately twice as many attacks, 19, range 2-165, as males, nine, range $1-42, \mathrm{p}<0.01$, MannWhitney U test. Since the start of HAE symptoms ( $\mathrm{n}=99), 9 \%$ had experienced fewer than one attack, $15 \%$ one to five attacks, $28 \%$ six to 11 attacks, $36 \% 12$ to 24 attacks and $11 \%$ had had more than 24 attacks yearly (Figure 5). 


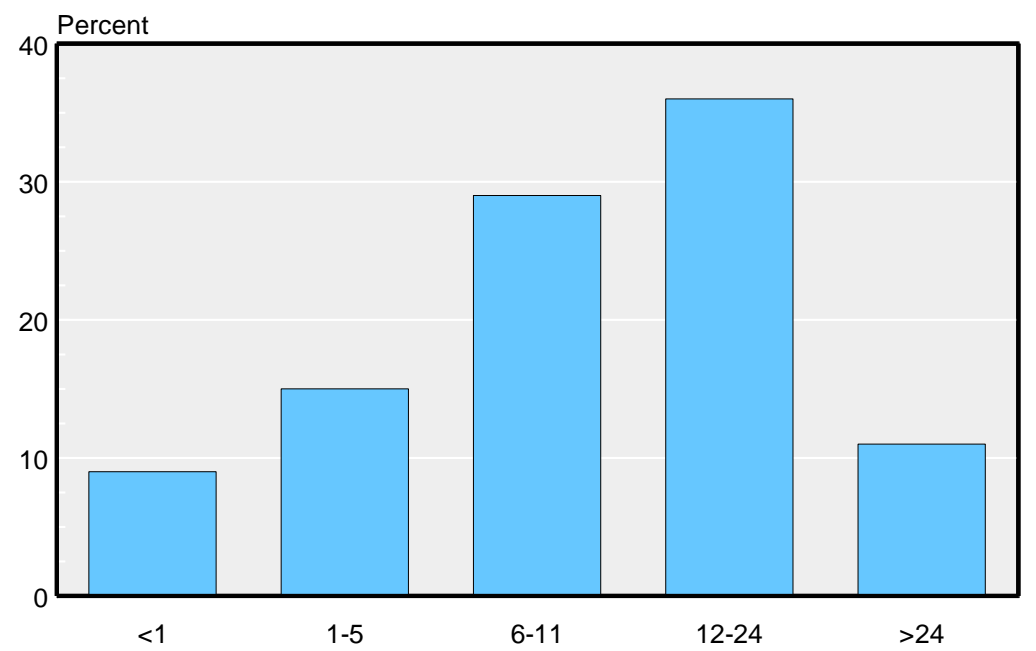

Figure 5. Distribution of the numbers of HAE attacks on average per year since onset of HAE symptoms in adults $(\mathrm{n}=99$, median age 39 , range $18-82$ years).

From the start of HAE symptoms, $82 \%$ usually had attacks affecting the skin, $78 \%$ the abdomen, 27\% the larynx, 26\% the urogenital area, $20 \%$ the lips, and $6 \%$ the tongue $(n=98$, Figure 6).

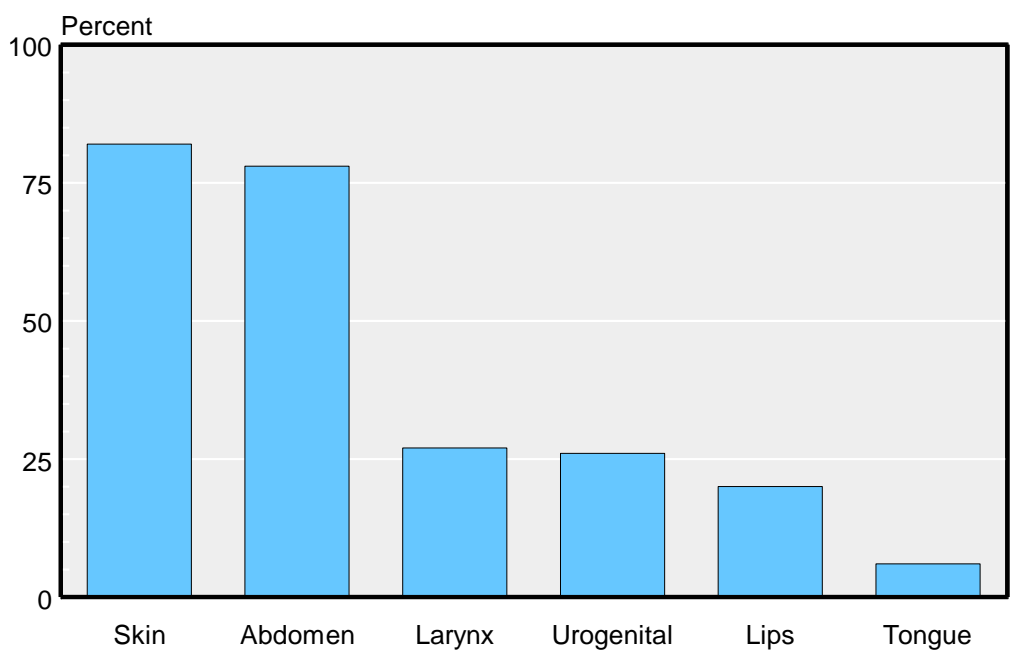

Figure 6. Proportion of adult patients according to where they usually have had their attacks since onset of symptoms $(\mathrm{n}=98$, median age 39 , range $18-82$ years). 
We defined the HAE attack frequency as severe if the patient had experienced 12 or more attacks during the last 12 months, as moderate with four to 11 attacks, as mild with one to three attacks, and as asymptomatic with no attacks. During the previous 12 months, $47 \%$ had severe, $21 \%$ had moderate, and $11 \%$ had mild HAE attack frequency, while $22 \%$ were asymptomatic $(n=96$, Figure 7$)$. Four patients who stated that they had angioedema were excluded from that analysis because of missing data from the written questionnaire.

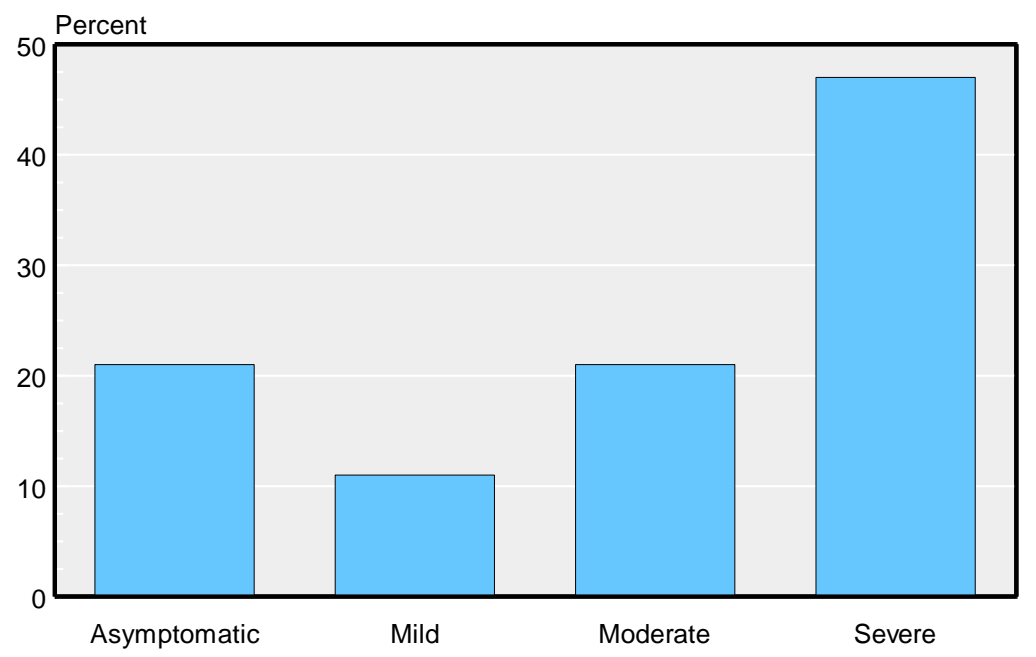

Figure 7. Distribution of adult patients, $(n=99$, median age 39 , range $18-82$ years $)$ according to severity of HAE attack frequency. The severity was defined by the number of attacks the previous year, where 0 attacks was defined as asymptomatic, 1-3 attacks as mild, 4-11 as moderate and $\geq 12$ as severe.

When patients were asked about their worst attack frequency during their lives, $40 \%$ had had on average 2.8 attacks per week, 45\% 3.9 attacks per month, and $15 \% 4.0$ attacks per year $(n=94)$. Furthermore, when attacks were at their worst, 3\% had an attack duration shorter than 12 hours, 9\% 12-24 hours, 3\% 1-2 days, 72\% 2-5 days, and $12 \%$ a duration longer than five days $(\mathrm{n}=97)$.

Irrespective of location, $66 \%$ had severe pain, $11 \%$ moderate, $9 \%$ mild and $14 \%$ no pain in association with HAE attacks $(n=96)$. In addition, $5 \%$ had perceived severe, $13 \%$ moderate, and $24 \%$ mild itching, whereas $57 \%$ had no itching during attacks $(n=97)$.

Concerning redness in areas with skin angioedema, 17\% always experienced it, $47 \%$ sometimes experienced it and 36\% never experienced it $(n=71)$. Only those who had experienced angioedema in the previous year answered this question. 
Prodromes were experienced by $68 \%(\mathrm{n}=98)$. Of these patients, $27 \%$ had tiredness, $24 \%$ physical sensations like paraesthesia and/or pain, $22 \%$ altered mental state (e.g. anxiety, moodiness, depression), $21 \%$ rash, $9 \%$ abdominal sensations, $7 \%$ increased appetite and $4 \%$ nausea. Twenty-one percent had more than one type of prodrome.

\section{Children}

The median number of attacks in those having attacks the previous year was six (1-46) $(n=23)$. Since the onset of HAE symptoms, $83 \%$ of the symptomatic children most frequently experienced attacks affecting the abdomen, $71 \%$ the skin, $17 \%$ the urogenital area, $13 \%$ the lips, $4 \%$ the larynx, and $0 \%$ the tongue. Of the 23 patients with symptoms, 22 (96\%), 11 boys and 11 girls, had abdominal attacks, making the abdomen the site affected in most individuals.

Irrespective of location, $69 \%$ reported severe pain, $13 \%$ moderate, $9 \%$ mild and $9 \%$ no pain in association with HAE attacks $(n=23)$.

Concurrent vomiting with abdominal attacks was experienced by 18 patients; 10 of the 11 boys and eight of the 11 girls. Diarrhoea was described during abdominal attacks by seven patients; four of the 11 boys and three of the 11 girls. Seven patients experienced pain during micturition, but this was only connected to an abdominal attack in two cases.

Since start of having symptoms of HAE had 18 (78\%) of the 23 patients, nine boys and nine girls, experienced skin swelling at least at one occasion. Erythematous swelling was described by 14 patients (78\%), eight of them experiencing this on every occasion. Fourteen patients $(78 \%)$ experienced pain in association with the skin attacks, six of them on every occasion, and nine $(50 \%)$ of the 18 patients reported itching, five of them on every occasion. The affected locations were specified by 17 patients and these were the hands $(n=15)$, feet $(n=12)$, head/face $(n=12)$, thorax $(n=12)$, arms $(n=9)$, legs $(n=5)$ and genital area $(n=5)$.

Also, since start of having symptoms of HAE had 12 patients (52\%), seven girls and five boys, had HAE attacks in the mouth and/or upper airways at least at one occasion. Six patients had breathing difficulties, and three had problems to swallow. One patient had a feeling of suffocation on two occasions, and in one of these the patient was intubated and treated with assisted ventilation in the intensive care unit.

Prodromal symptoms were reported by $11(48 \%)$ of the 23 patients, seven with a feeling of general discomfort, namely tiredness and irritability, and four with skin symptoms, namely itching, rash and/or paraesthesia.

We defined the HAE attack frequency in the child as severe if the patient had experienced 12 or more attacks during the last 12 months, as moderate with four to 11 attacks, as mild with one to three attacks, and as asymptomatic with no attacks. Severe attack frequency was seen in $11(48 \%)$ patients, moderate in seven $(30 \%)$ and mild in two $(9 \%)$, while three $(13 \%)$ being asymptomatic. 


\section{Trigger factors}

\section{Adults}

Trigger factors that provoked HAE attacks were detected in 94 of 99 patients $(95 \%)$. Triggers were trauma (56\%), mental stress (55\%), infection (35\%), physical exertion (13\%), alcohol (4\%), cold conditions (3\%) and menstruation (in 33\% of women) (Figure 8). Attacks without any obvious trigger were experienced by $62 \%$.

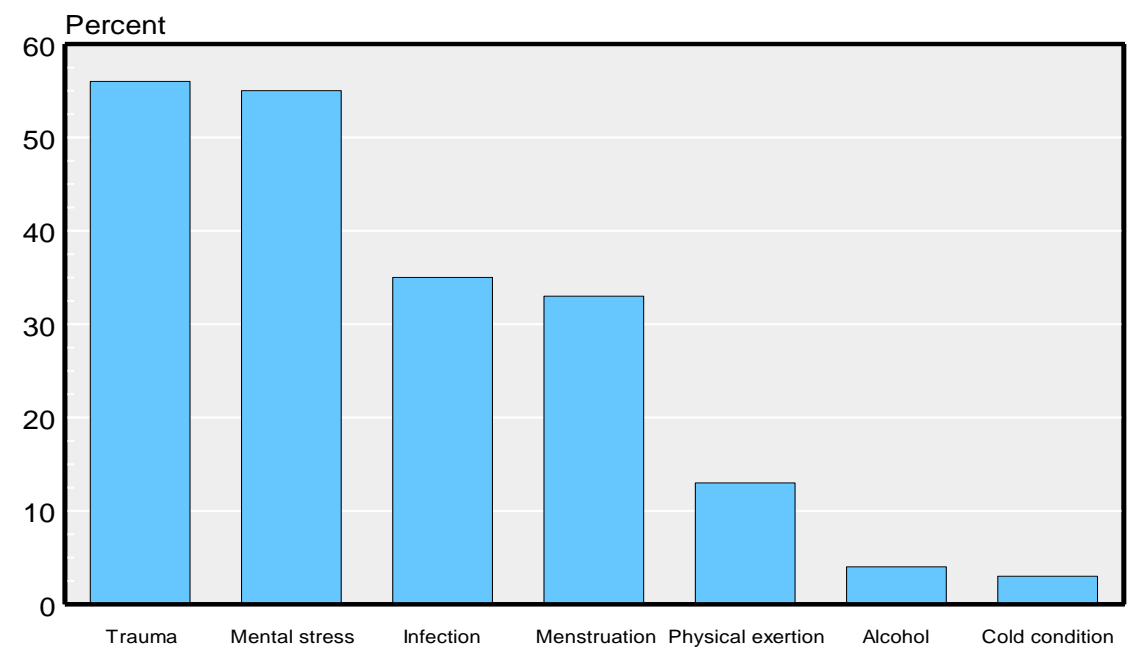

Figure 8. Proportion of adult patients reporting certain factors triggering their HAE attacks $(n=94$, median age 39.5, range 18-82 years, except for menstruation where $n=47$, median age 38, range 18-64 years)

\section{Children}

Triggers for HAE attacks were described by 17 (74\%) of the 23 patients. Abdominal attacks were often triggered by psychological stress and upper airway infections, while trauma and sports were the most common triggers for skin swelling (Figure 9). 


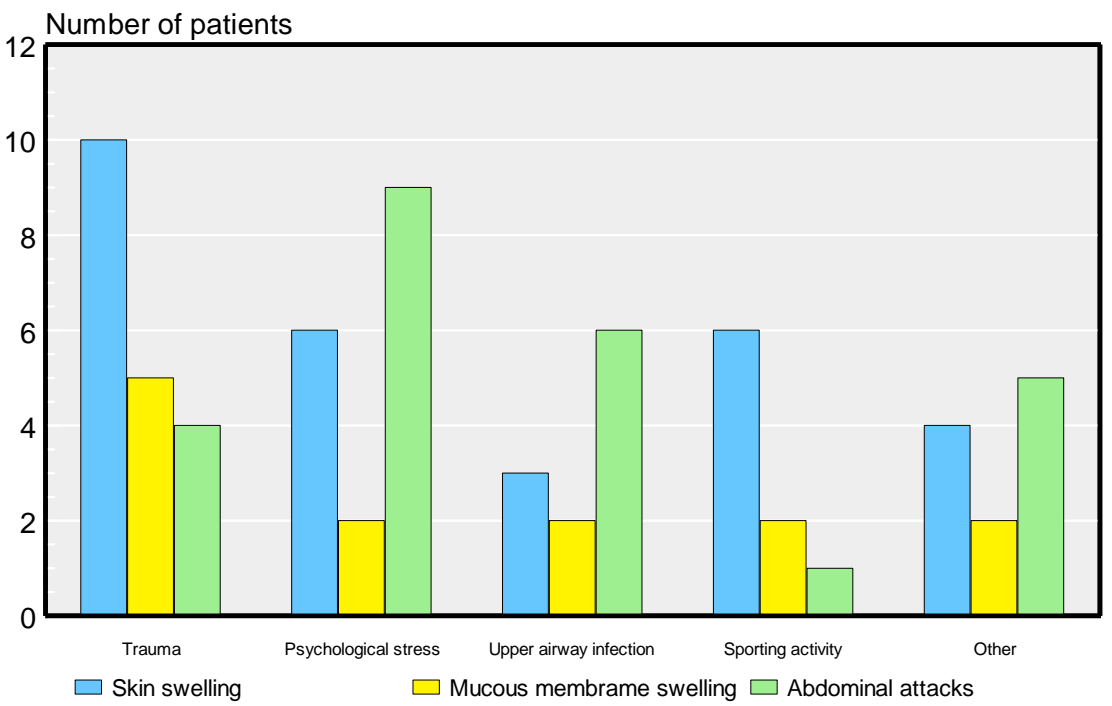

Figure 9. Trigger factors in 17 Swedish children with hereditary angioedema with symptoms. Abdominal attacks were to a large extent triggered by psychological stress and upper airway infections and skin swelling by trauma and sporting activity. Other causes were surgery $(n=1)$, oral contraceptives $(n=1)$ or not specified $(\mathrm{n}=7)$. Mucous membranes include lips, tongue, pharynx, and genital area.

None of the 11 patients who had received local anaesthesia had any side effects or concurrent HAE symptoms. Furthermore, none of these patients experienced any HAE symptoms due to vaccinations carried out according to the Swedish standard vaccination schedule.

\section{Treatment}

\section{Adults}

Patients were asked about treatment of acute attacks. They also graded the treatment effect as none, poor, moderate or very good (Table II). PdC1INH had been used in $27 \%$ of the patients for acute treatment of all locations of attacks with very good effect. Eight percent had been treated with fresh frozen blood plasma with a moderate effect on abdominal attacks and with no effect on laryngeal attacks. Tranexamic acid had been used as an acute treatment in $16 \%$ with a poor effect on skin swellings and no effect on abdominal or laryngeal attacks. Androgens had at best a poor-to-moderate effect when used in $2 \%$ of patients on acute skin attacks. Other acute treatments were epinephrine, antihistamines, glucocorticoids, NSAIDs, and opioids (Table II). 
Table II. Proportion of adult patients $(\%)$ reporting certain treatments for acute attacks $(\mathrm{n}=98$, median age 39, range 18-82 years). The median overall treatment effect was rated on a 4-step scale (no=0, poor $=1$, moderate $=2$ and very good effect $=3$ ). ${ }^{\mathrm{a}}$ Plasma derived $\mathrm{C} 1$-inhibitor, ${ }^{\mathrm{b}}$ Non-steroidal antiinflammatory drugs.

\begin{tabular}{lcccccccc}
\hline Treatment & \multicolumn{2}{c}{ Skin } & \multicolumn{2}{c}{ Abdomen } & Larynx & \multicolumn{2}{c}{ Urogenital } \\
\cline { 2 - 9 } & $\%$ & Effect & $\%$ & Effect & $\%$ & Effect & $\%$ & Effect \\
\hline PdC1INH $^{\mathbf{a}}$ & 13 & 3 & 20 & 3 & 27 & 3 & 1 & 2 \\
$\begin{array}{l}\text { Fresh-frozen } \\
\text { plasma }\end{array}$ & 8 & 1 & 6 & 2 & 8 & 0 & 0 & - \\
Tranexamic acid & 13 & 1 & 8 & 1 & 16 & 0 & 0 & - \\
Androgens & 4 & 1 & 1 & 0 & 0 & - & 0 & - \\
Intubation & 0 & - & 0 & - & 6 & 3 & 0 & - \\
Opioids & 0 & - & 10 & 2 & - & - & - & - \\
Epinephrine & 12 & 1 & 5 & 2 & 27 & 1 & 0 & - \\
NSAIDs & 0 & - & 9 & 2 & 0 & - & 0 & - \\
Diuretics & 1 & 0 & 3 & 2 & 0 & - & 0 & - \\
Glucocorticoids & 18 & 1 & 6 & 0 & 25 & 0 & 1 & 2 \\
$\begin{array}{l}\text { Antihistamines } \\
\text { Others }\end{array}$ & 9 & 1 & 1 & 0 & 14 & 0 & 0 & - \\
\hline & 5 & 1 & 10 & 0 & 3 & 1 & 0 & - \\
\hline
\end{tabular}

Eighty-eight adults had used prophylactic treatment at some time during their lives, in the form of antifibrinolytics (49\%), androgens (43\%) and/or pdC1INH (8\%). While antifibrinolytics had no preventive effect on attack frequency, in general attenuated androgens and pdC1INH reduced the annual attack frequency by more than $50 \%$. At the time of answering the questionnaire, 22 of the 88 patients (25\%) were on androgens and two had previously used attenuated androgens. Fourteen had experienced side effects; nine females and five males. The side effects were: weight gain $(n=9)$, altered menstruation $(n=4)$, acne $(n=3)$, virilisation $(n=2)$, hyperlipidaemia $(n=1)$, hypertension $(n=1)$ and tiredness $(n=1)$. Seven had more than one side effect. Nobody experienced any major cardiovascular event such as myocardial infarction or stroke using attenuated androgens. 


\section{Children}

Intravenous injections of pdC1INH had been received by nine patients, some of them due to symptoms from various loci: six due to abdominal attacks, four due to laryngeal attacks and four due to skin swelling. Antifibrinolytics, in the form of tranexamic acid, had been used by five patients as an acute treatment, but none had received fresh frozen plasma.

In study II, access to pdC1INH at home was reported by $19(66 \%)$ of the 29 children, with a median age of nine years and a range of 1-17. Of these, five could be given an intravenous injection at home by a trained relative if necessary.

Among the children, nine patients were using long-term prophylactic treatment. Four of them were using antifibrinolytics as tranexamic acid, one was using a combination of tranexamic acid and pdC1-INH and four, three teenage boys and a 16-year-old girl, were using androgens, in the form of oxandrolone. Another three patients had previously used tranexamic acid as prophylaxis.

\section{Health care visits and sick leave}

\section{Adults}

Since start of symptoms, females had a median of 15 health care visits (range 0-100, $\mathrm{n}=48$ ) and males 10 (range $0-500, \mathrm{n}=51$ ) due to HAE. Females were hospitalised in median of three times (range 0-60, $n=46$ ) and males twice (range $0-100, n=50$ ) because of HAE since the onset of HAE attacks. During the previous year, females had in median significantly more days of sick leave than males (10, range $0-183, n=37$ vs 4 , range 0-365, $n=35 ; \mathrm{p}<0.05$, Mann-Whitney $U$ test).

\section{Children}

The parents of $73 \%$ of the children with manifest HAE had to take leave to care for their children due to HAE symptoms. The most common reason for taking leave was their child's abdominal attacks $(n=15)$, followed by skin swelling $(n=7)$. One 15 -year-old boy stayed at home without parental supervision during HAE attacks.

\section{Quality of life and health assessment: children (study II)}

The median level of current health for the 23 children with symptomatic HAE was four (good) on the five-step scale, ranging from two to five, with a mean and standard deviation (SD) of $4.26(0.79)$. The 12 boys had a mean of $4.42(0.64)$ and the 11 girls had a mean of 4.09 (0.90). The median level of health for the eight children without symptomatic HAE was also four (good) with a range of four to five and a mean of $4.38(0.48)$.

The median value for QoL on the seven-step scale, based on responses for 21 of the 23 children with symptomatic HAE, was six, with a range of three to seven and a mean 
(SD) of 5.86 (1.28). The 11 boys had a mean of 6.18 (1.11) and the 10 girls scored 5.5 (1.36), the difference between boys and girls was not significant.

The median value for the QoL of the 23 children with HAE symptoms, as rated by the parents, was six, with a range of three to seven, and the mean was 5.96 (1.08). It was 6.08 (1.04) for the 12 boys and 5.82 (1.11) for the 11 girls. The median QoL value for the eight children who had not yet experienced HAE symptoms was 6.5, and the range was six to seven, with a mean of $6.50(0.50)$.

\section{Reproductive health among females}

A summary of the influence of menarche, anticonception, pregnancy and menopause on HAE symptoms is given in Table III.

Table III. Reported influence on HAE symptoms of various factors in adult females. Symptoms are graded in three steps from worse, no change to improved. No HAE symptom yet, means that the HAE was not symptomatic yet. Data in percent and type values in bold $(n=48$, median age 38.5 , range 18-82 years). *One female was excluded because she was better during one pregnancy and worse during another.

\begin{tabular}{lccccc} 
Event & Worse & $\begin{array}{c}\text { No } \\
\text { change }\end{array}$ & Improved & $\begin{array}{c}\text { Not an- } \\
\text { swered }\end{array}$ & $\begin{array}{c}\text { No HAE } \\
\text { symptoms } \\
\text { yet }\end{array}$ \\
\hline $\begin{array}{l}\text { The year of } \\
\text { menarche (n=48) }\end{array}$ & $\mathbf{3 0 \%}$ & $22 \%$ & $0 \%$ & $0 \%$ & $48 \%$ \\
$\begin{array}{l}\text { Estrogen anti- } \\
\text { conception (n=32) }\end{array}$ & $\mathbf{6 6 \%}$ & $22 \%$ & $0 \%$ & $6 \%$ & $6 \%$ \\
$\begin{array}{l}\text { Gestagen anti- } \\
\text { conception (n=23) }\end{array}$ & $13 \%$ & $\mathbf{7 0 \%}$ & $9 \%$ & $0 \%$ & $9 \%$ \\
$\begin{array}{l}\text { IUD anticoncep- } \\
\text { tion (n=31) }\end{array}$ & $10 \%$ & $\mathbf{6 5 \%}$ & $6 \%$ & $16 \%$ & $3 \%$ \\
$\begin{array}{l}\text { Pregnancy } \\
\text { (n=42)* }\end{array}$ & $\mathbf{5 5 \%}$ & $14 \%$ & $24 \%$ & $0 \%$ & $7 \%$ \\
$\begin{array}{l}\text { Menopause } \\
\text { (n=15) }\end{array}$ & $0 \%$ & $\mathbf{6 0 \%}$ & $40 \%$ & $0 \%$ & $0 \%$ \\
\hline
\end{tabular}


Five of 43 females who had been pregnant had complications during labour; fever $(n=1)$, bleeding $(n=1)$, difficulty in delivering the placenta $(n=1)$, urinary tract infection $(\mathrm{n}=1)$, and an HAE attack $(\mathrm{n}=1)$.

Caesarean sections were carried out in nine of the 43 patients, for reasons including foetal stress $(n=4)$, delivery-related complications $(n=2)$, and HAE $(n=2)$; one intervention was planned $(n=1)$, and one was given for a reason unknown to the patient $(n=1)$. One patient had made caesarean sections twice. Twelve females had experienced miscarriages. In two cases, the foetuses were growth-retarded, in one case there was an intra-uterine death of the foetus, and in another the pregnancy was ectopic. The cause of miscarriage was unknown in the remaining eight cases. 


\section{HR-QoL in patients with HAE: EQ-5D-5L during and between attacks (studies III and IV)}

At the time for the study III we had 144 patients in the Sweha-Reg, only 139 questionnaires were sent out, because five patients had stated that they did not want to participate in any further investigations. From the total of 107 responses collected, two blank questionnaires were excluded, leaving 105 for analysis. Of those 105, 54 were females (mean age 41, range 10-88 years), and 51 were male (mean age 41, range 4-89 years). Of the 51 males, nine were younger than 12, and four were between 12 and 18 years. Of the 54 females, four were younger than 12, and four were between 12 and 18 years.

One-hundred and five had an EQ-5D-5L between attacks (EQ5D today) score mean (SD) $0.82(0.20)$ and 98 out of 105 patients' EQ-5D-5L were statistically lower during an attack with HAE (EQ5D attack) utility value $0.54(0.31)(\mathrm{p}<0.0001$, t-test) (Figure $10)$.

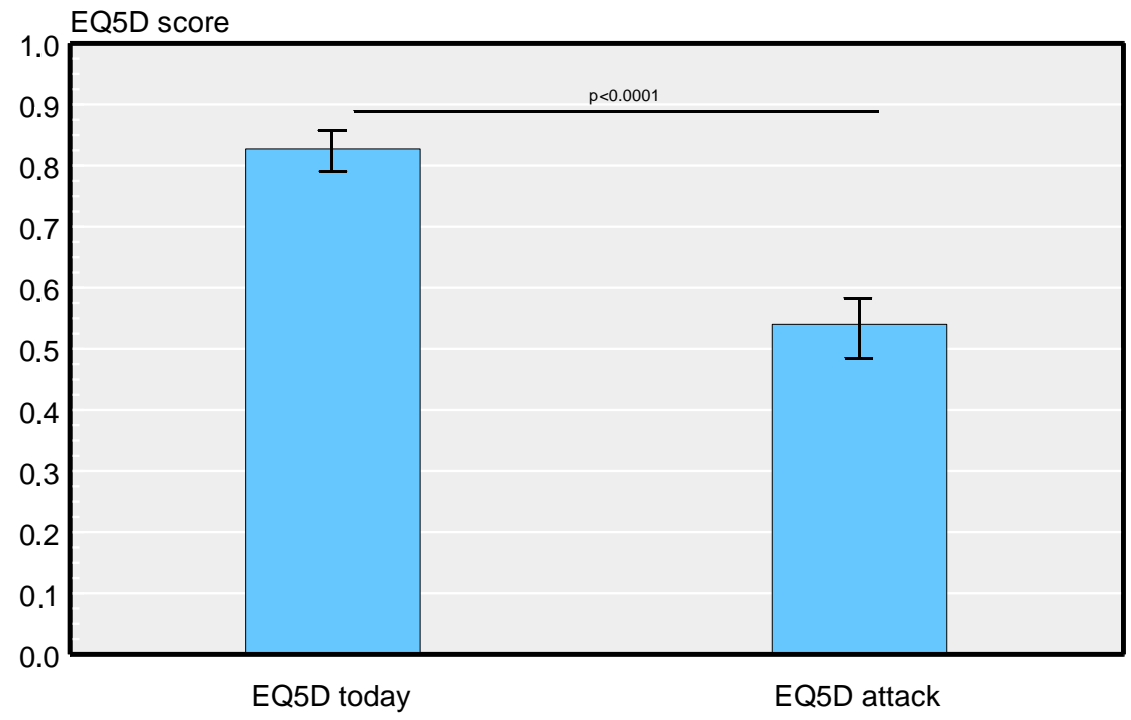

Figure 10. EQ5D today ( $\mathrm{n}=105$ median age 41 , range $2-87$ years) and EQ5D attack ( $\mathrm{n}=98$, median age 41.5 , range 2-86 years) values. Results are shown as mean and $95 \%$ confidence interval.

Females had a lower but not significantly lower EQ5D today value than males, means and (SD) $0.81(0.21)$ vs $0.85 \quad(0.20), \quad(p=0.25$, t-test). The females $(n=53)$ had statistically significant lower EQ5D attack values than males $(n=45) 0.47(0.32)$ vs 0.62 
$(0.28)(\mathrm{p}=0.01 \mathrm{t}$-test). With increasing attack severity, the EQ5D attack value was lower and the difference between EQ5D today and EQ5D attack was larger. A significant difference between the EQ5D today and EQ5D attack scores of their latest attack was observed for both mild $(0.09, \mathrm{p}<0.05$, t-test $)$, moderate $(0.34, \mathrm{p}<0.001$, t-test $)$ and severe attacks $(0.56, \mathrm{p}<0.001, \mathrm{t}$-test) (Figure 11).

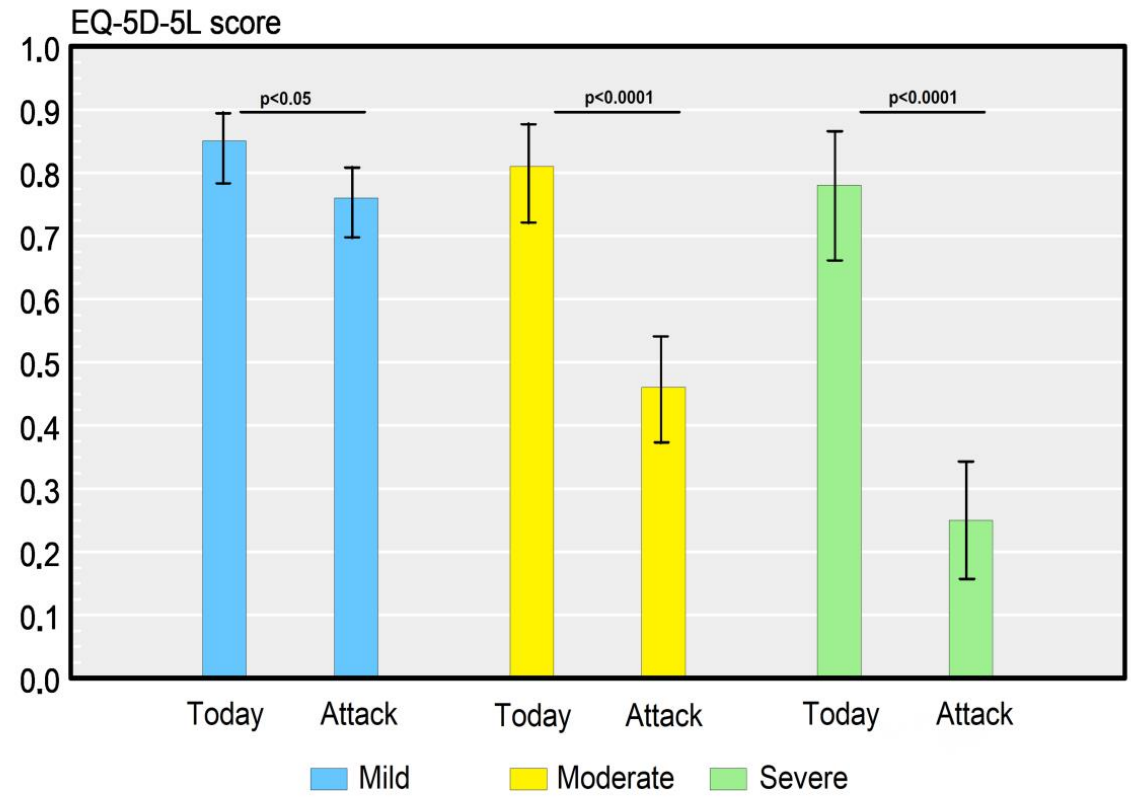

Figure 11. EQ5D today and EQ5D attack values grouped according to the severity of the last attack. Mild, moderate, and severe today refers to the EQ5D today value in patients reporting that their last attack was mild ( $n=43$, median age 42 , range $11-74$ years), moderate ( $n=27$, median age 40 , range 2-86 years) or severe $(n=20$, median age 43 , range $11-63$ years).

The most affected dimensions in EQ5D today were pain/discomfort, with a mean value and SD of 1.7 (1.0), and anxiety/depression, with a mean value of 1.6 (0.7). In EQ5D attack, the most affected dimensions were pain/discomfort, with a mean of 2.7 (1.1), and usual activities 2.6 (1.4).

In study III the EQ-5D-5L utility value among the 22 responding children was in mean significantly better than among the 83 adults at $0.91(0.14)$ vs $0.81(0.21)(\mathrm{p}<0.05$, Mann-Whitney U test). In study IV, EQ-5D-5L was $0.77(0.26), n=63$, adults only. The EQ5D attack scores in the 12 responding children were $0.43(0.31)$ and in the responding 82 adults $0.54(0.31)$, a difference which was not significant between the 
adults and the children. The children had in mean fewer annual attacks than the adults: 8.6 (11.3) vs 10.7 (17.1), but the difference was not significant.

The 101 that both stated an EQ5D today and annual attack frequency were divided into three subgroups defined by recorded annual attack frequency; low is 0-14 attacks per year ( $n=83$ ), medium 15-29 attacks per year $(n=8)$, and high $\geq 30$ attacks per year $(n=10)$. The low attack frequency group had an EQ-5D-5L value of in mean $0.84(0.19)$ and the medium frequency attack group had a value of $0.84(0.15)$ and the high frequency attack group $0.68(0.29)$. The high frequency group had statistically significant lower EQ-5D-5L value than the low attack frequency group $(\mathrm{p}<0.05 \mathrm{t}$-test) (Figure 12)

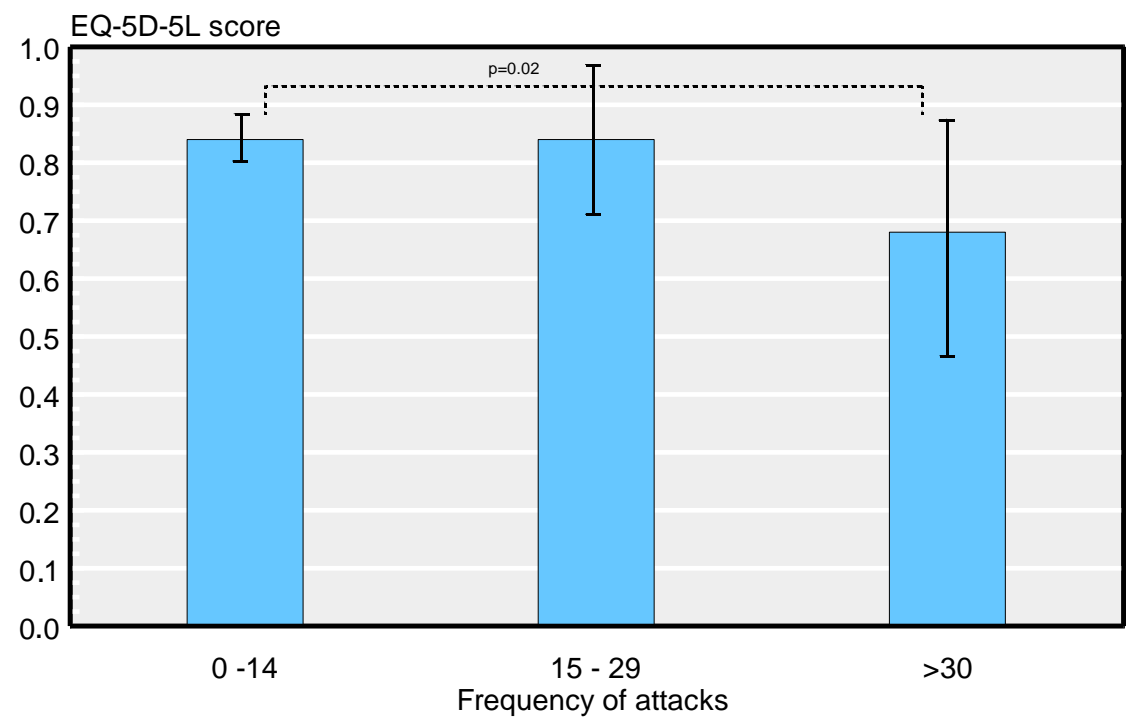

Figure 12. EQ-5D-5L according to frequency or number of attacks last year. $\mathrm{N}=101, \mathrm{p}<0.005$ between group with 0-14 attacks last year and group with >30 attacks last year. Low frequency group (0-14) n=83, median age 41 , range 10-63 years, medium frequency group (15-29) $n=8$, median age 27 , range 11-60 years and high frequency group (>30) median age 41 , range $10-63$ years. 


\section{HR-QoL using multiple instruments}

\section{Demography (study IV)}

The study population in study IV included 64 adult patients, giving a response rate of $48 \%$ (Figure 3 ). Thirty-eight females with a median age of 50 years (range 18-91) and 26 males with a median age of 53 years (range 20-79) participated. Sixty were diagnosed with HAE type I and four with type II. Differences in demography between responders and non-responders are shown in Table IV.

Table IV. Comparison between responders and non-responders. Numbers marked in bold denote $\mathrm{p}<0.05$.

\section{Responders $(\mathbf{n}=64)$}

Non-responders $(\mathrm{n}=69)$

\begin{tabular}{lcc}
\hline Males & 26 & 36 \\
Females & 38 & 33 \\
Median age all (range) & $\mathbf{5 1}(\mathbf{1 8 - 9 1 )}$ & $\mathbf{4 1}(\mathbf{1 8 - 7 9 )})$ \\
$\begin{array}{l}\text { Median age males (range) } \\
\text { Median age females }\end{array}$ & $\mathbf{5 3}(\mathbf{2 0 - 7 9 )}$ & $\mathbf{4 2}(\mathbf{2 0 - 7 9 )})$ \\
(range) & $\mathbf{5 4}(\mathbf{1 8 - 9 1 )}$ & $\mathbf{4 1}(\mathbf{2 2 - 7 5 )})$ \\
$\begin{array}{l}\text { HAE Type I } \\
\text { HAE Type II }\end{array}$ & 60 & 65 \\
$\begin{array}{l}\text { Patients with known af- } \\
\text { fected family members }\end{array}$ & 4 & 4 \\
$\begin{array}{l}\text { Living in rural area } \\
\text { Living in urban areas } \\
\text { outside the three major } \\
\text { cities }\end{array}$ & 28 & 1 \\
$\begin{array}{l}\text { Living in the three major } \\
\text { cities }\end{array}$ & 2 & 50 \\
\hline
\end{tabular}




\section{HR-QoL instruments (study IV)}

The HR-QoL dimensions most affected among HAE patients were:

(I) pain/discomfort and anxiety/depression on the EQ-5D-5L (Table V)

(II) energy/fatigue, general health, health transition and pain on the RAND-36 (Table VI)

(III) fears/shame and fatigue/mood on the AE-QoL (Table VI)

Table V. Gender differences between the different dimensions of EQ-5D-5L. Problems are a summation of the answer alternatives slight problems, moderate problems, severe problems and extreme problems. No significant differences were seen between males and females.

*One female answered the VAS-scale of EQ-5D-5L but not the other questions and is therefore missing.

\begin{tabular}{llcc} 
EQ-5D-5L dimensions & Answer & Male $(\mathbf{n = 2 6})$ & Female $(\mathbf{n = 3 7})^{*}$ \\
\hline Mobility & No problems & $19(73 \%)$ & $25(68 \%)$ \\
& Problems & $7(27 \%)$ & $12(32 \%)$ \\
Self-care & No problems & $22(85 \%)$ & $30(77 \%)$ \\
& Problems & $4(15 \%)$ & $7(23 \%)$ \\
Usual activities & No problems & $19(73 \%)$ & $21(57 \%)$ \\
& Problems & $9(27 \%)$ & $16(43 \%)$ \\
Pain/discomfort & No problems & $15(58 \%)$ & $17(46 \%)$ \\
& Problems & $11(42 \%)$ & $20(54 \%)$ \\
Anxiety/depression & No problems & $12(46 \%)$ & $18(49 \%)$ \\
& Problems & $14(54 \%)$ & $19(51 \%)$ \\
\hline
\end{tabular}




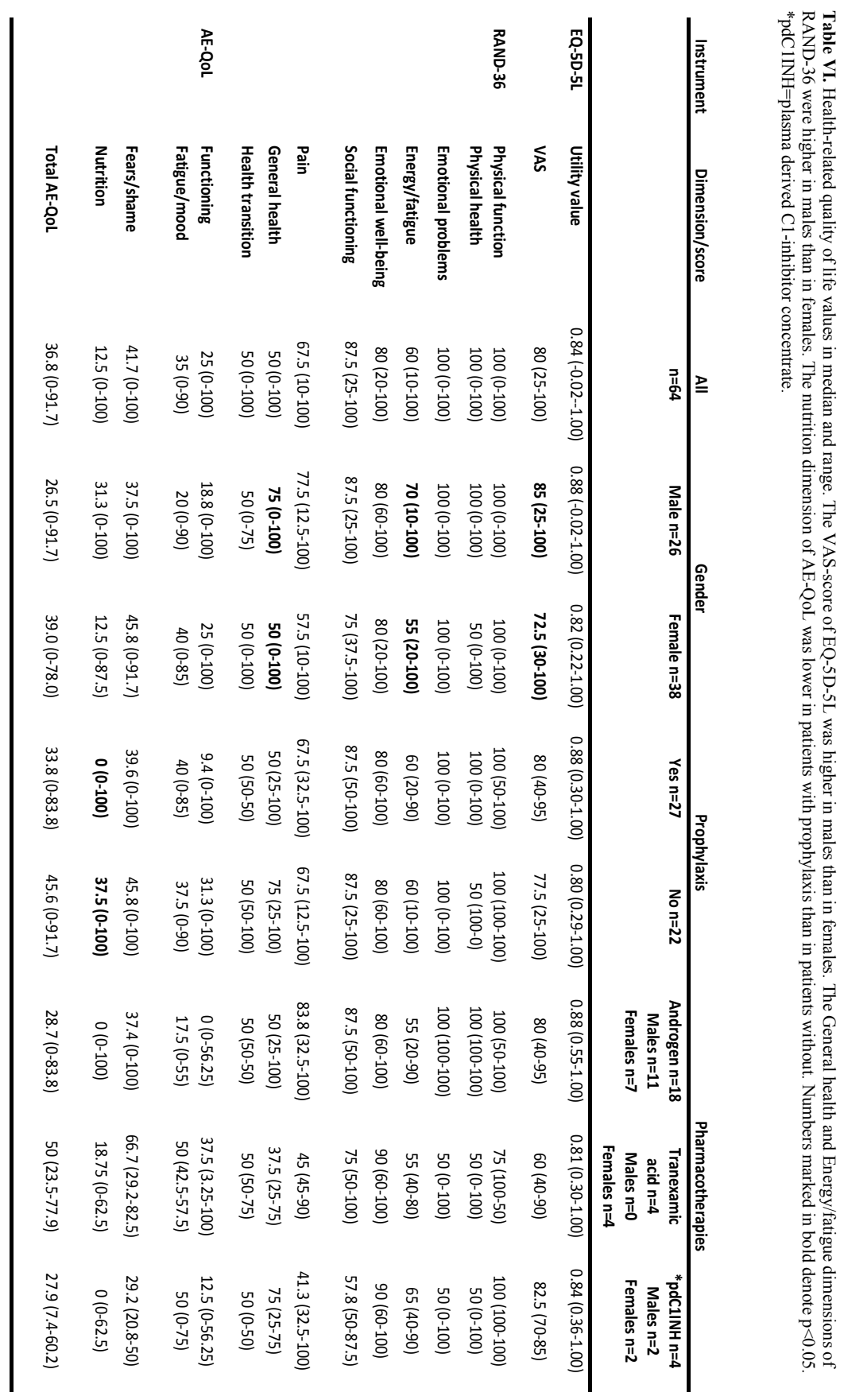


Females had significantly lower VAS scores on the EQ-5D-5L, and HR-QoL in the dimensions of energy/fatigue and in general health on the RAND-36 ( $p<0.05$, KruskalWallis), but otherwise no significant differences were detected between the sexes (Tables V and VI).

There were no significant differences in HR-QoL in patients with and without prophylactic treatment, except in the nutrition dimension of the AE-QoL ( $p<0.05$ KruskalWallis) (Table VI).

\section{Associations between EQ-5D-5L or RAND-36 and AE-QoL (study IV)}

All scores from the dimensions of the AE-QoL were significantly associated, using the Rank Spearman order $(\mathrm{p}<0.05)$, with the utility value of EQ-5D-5L, and with all scores from the dimensions of the RAND-36, except that the scores for the fears/shame dimension of the AE-QoL did not show any association with the RAND-36 dimensions of physical function, physical health and health transition (Table VII).

\section{AAS28}

Of the 55 patients who answered the AAS28, 48 also answered the EQ-5D-5L, RAND 36 and AE-QoL afterwards. Twenty-four had no HAE activity, 14 had low scores, and nine had moderate scores on the AAS28. Those whose AAS28 scores were above 0 showed a trend for more impaired HR-QoL (Table VIII). One male with the extreme score of 192 was excluded, since he strongly biased the results, raising the mean score by $19 \%$. 


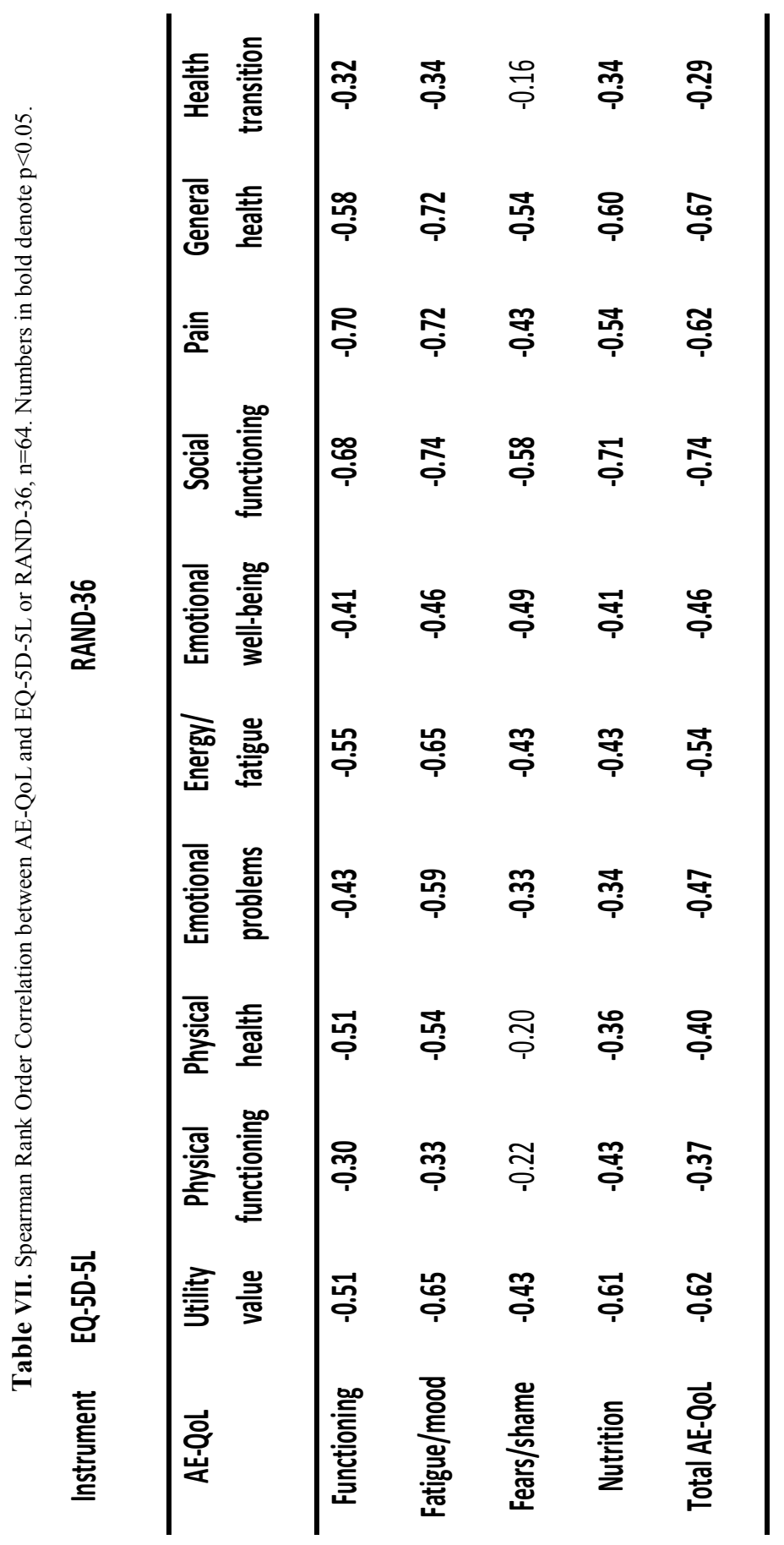




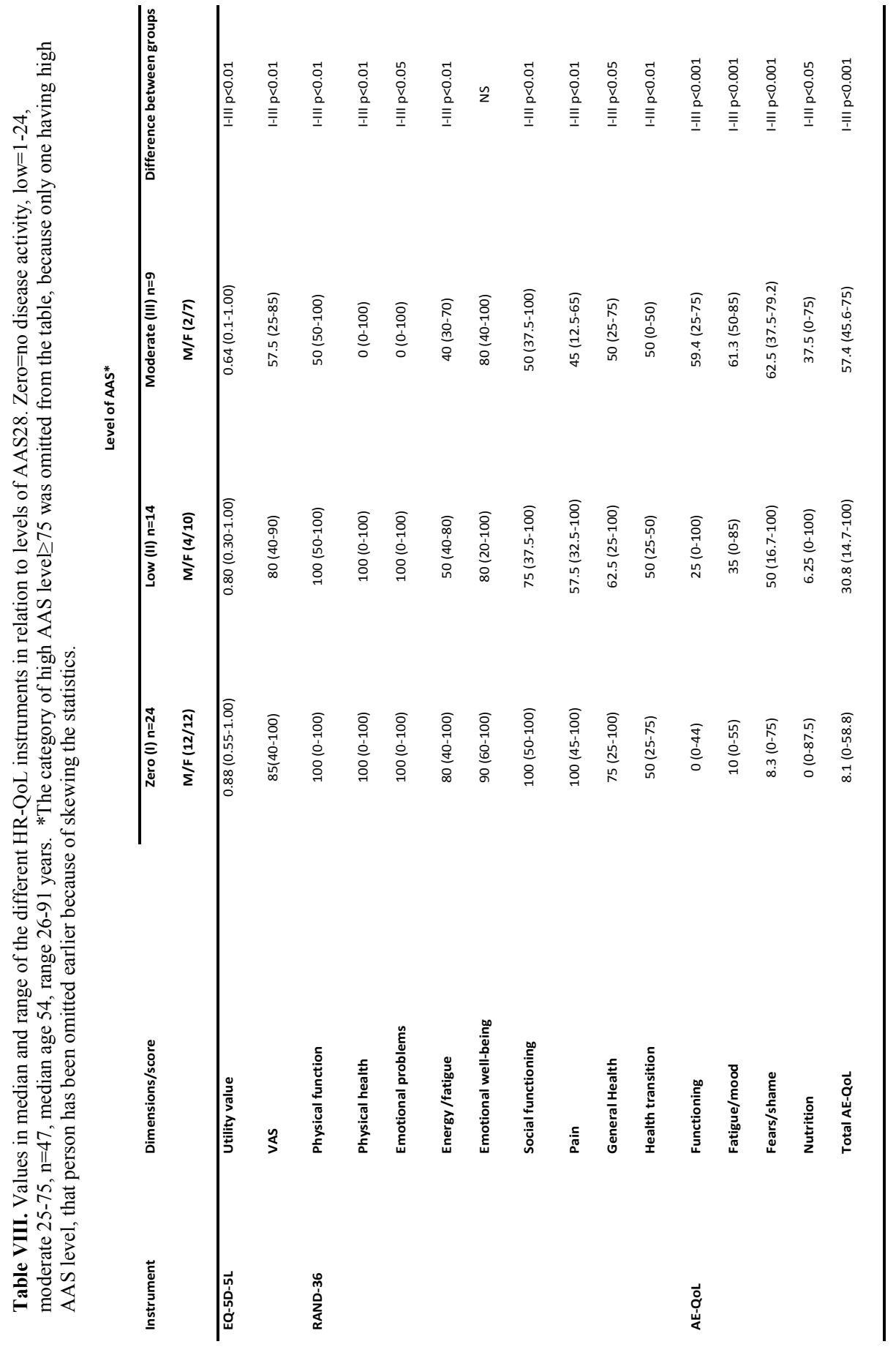




\section{Associations between AAS28 and HR-QoL instruments}

The mean AAS28 score and standard deviation (SD) among males were 18.2 (33.3) and the median was 0 (range 0-118) due to skewed distribution. The females' mean and SD were 16.4 (18.1) and the median was 13 (range 0-63). The differences between males and females on the AAS28 were not statistically significant.

There were statistically significant associations using the Spearman Rank order between the AAS28 and EQ-5D-5L, all dimensions of the RAND-36 except physical function, and all dimensions of the AE-QoL (Table IX). On the EQ-5D-5L, the correlation between the AAS28 and utility values was lower than the correlation between the AAS28 and VAS score (Table IX). On the RAND-36, the highest correlations were seen in the dimensions of pain, energy/fatigue, social functioning, and physical health (Table IX). The AE-QoL dimensions of functioning, fears/shame and fatigue/mood had the highest correlations (Table IX). The lowest correlation was seen in the RAND-36 dimension of physical function (Table IX).

The AAS28 correlations with HR-QoL instruments were compared with the correlations for the number of days with attacks of HAE and the HR-QoL instruments, giving similar results (Table IX). 
Table IX. Spearman rank order correlations for AAS28 or number of attack days and the different HRQoL instruments and their dimensions, $n=47$, median age 54 range 26-91 years. As earlier noted, one outlier omitted because of skewing the statistics. Numbers in bold denote $\mathrm{p}<0.05$.

\begin{tabular}{lllc} 
& & \multicolumn{2}{c}{ Correlations } \\
\cline { 3 - 4 } Instrument & Dimensions/score & AAS28 & $\begin{array}{c}\text { Number of at- } \\
\text { tack days }\end{array}$ \\
\hline \multirow{2}{*}{ EQ-5D-5L } & Utility value & & $\mathbf{- 0 . 3 4}$ \\
& VAS & $\mathbf{- 0 . 3 5}$ & $\mathbf{- 0 . 4 5}$ \\
& Physical function & $\mathbf{- 0 . 4 5}$ & -0.18 \\
& Physical health & -0.20 & $\mathbf{- 0 . 5 0}$ \\
& Emotional problems & $\mathbf{- 0 . 5 0}$ & $\mathbf{- 0 . 3 9}$ \\
& Energy/fatigue & $\mathbf{- 0 . 4 1}$ & $\mathbf{- 0 . 5 9}$ \\
& Emotional well-being & $\mathbf{- 0 . 5 9}$ & $\mathbf{- 0 . 3 2}$ \\
Social functioning & $\mathbf{- 0 . 3 8}$ & $\mathbf{- 0 . 5 7}$ \\
& Pain & $\mathbf{- 0 . 5 8}$ & $\mathbf{- 0 . 6 5}$ \\
& General health & $\mathbf{- 0 . 6 4}$ & $\mathbf{- 0 . 4 2}$ \\
& Health transition & $\mathbf{- 0 . 4 3}$ & $\mathbf{- 0 . 4 3}$ \\
Functioning & $\mathbf{- 0 . 4 6}$ & $\mathbf{0 . 7 6}$ \\
& Fatigue/mood & $\mathbf{0 . 7 7}$ & $\mathbf{0 . 6 0}$ \\
Fears/shame & $\mathbf{0 . 6 1}$ & $\mathbf{0 . 6 0}$ \\
& Nutrition & $\mathbf{0 . 6 3}$ & $\mathbf{0 . 4 1}$ \\
& Total AE-QoL & $\mathbf{0 . 4 1}$ & $\mathbf{0 . 6 7}$ \\
\hline & & $\mathbf{0 . 6 9}$ &
\end{tabular}




\section{Prophylactic pharmacotherapy and HR-QoL (study IV)}

In study IV, there was no statistically significant difference in HR-QoL in patients with or without prophylactic treatment, except in the nutrition dimension of the AE-QoL (Table V). Patients with prophylaxis had lower AAS28 scores (median 0, range 0-40, $\mathrm{n}=27$ ), although not significantly, compared with those without prophylaxis (median 19, range $0-78, n=21$ ). Of those on prophylaxis, patients with androgens had the lowest AAS28 scores, albeit not significantly, (median 1, range 0-2, n=18), compared with patients on tranexamic acid (median 16, range 8-40, $\mathrm{n}=4$ ) or pdC1INH (median 20.5, range $0-118, n=4)$.

\section{Differences between baseline and follow-up}

By using Svensson's method, we discovered no major differences in the outcome between baseline and after four weeks in the different instruments. For all dimensions in all the instruments, the PA was near $100 \%$. Both RP and RC were approaching zero, and this indicates that the instruments were stable over a four-week period. The value of $\mathrm{RV}$ was also approaching to zero, indicating there was no heterogeneity in answers between the two time-points.

\section{Sick leave (studies III and IV)}

In study III, 89 of 105 participants (85\%) answered the question about sick leave during their latest acute attack and about the attack severity level. In total, 39 out of 89 participants reported that they had been away from day care, school or work during the latest attack. With increasing attack severity, the proportion of patients who were absent was significantly increased ( $\mathrm{p}<0.0001$, Fisher's Exact test). Sick leave during mild attacks was $13 \%$, during moderate attacks $50 \%$, and during severe attacks 91\%, (Figure 13). No significant relationship was detected between the location of the attack and patient sick leave. 


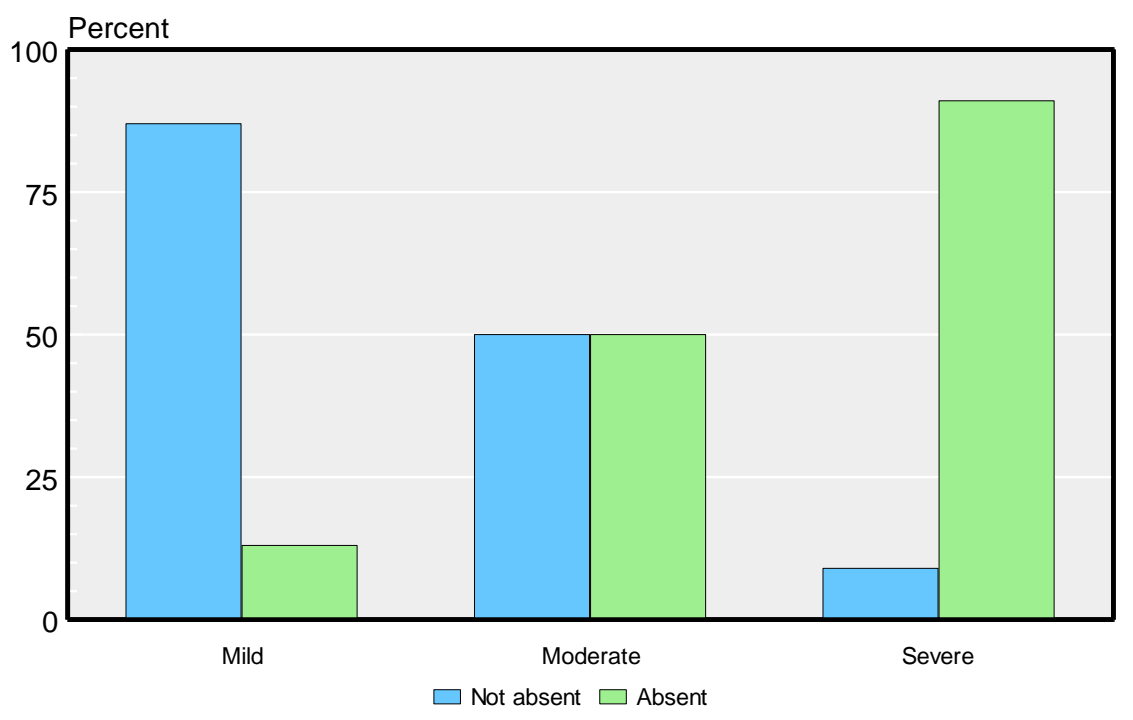

Figure 13. Percent absenteeism from day care, school or work in relation to self-reported attack severity for the latest attack ( $n=89$ with median age 41, range 2-86 years). Five out of 40 patients with mild attacks, 13 of 26 patients with moderate attacks, and 21 of 23 patients with severe attacks reported absenteeism. Absenteeism was significantly more likely with increasing attack severity $(\mathrm{p}<0.0001$, Fishers Exact test).

In study IV, of the 36 patients who gave information about sick leave, nine had taken sick leave because of HAE (median two days, range 0.25-8) during the prospective period of four weeks. More females than males had taken sick leave due to HAE (6 vs 3).

Those who took sick leave due to HAE in study IV statistically had significantly impaired HR-QoL than those who did not, using Kruskal-Wallis, in the EQ-5D-5L, in all dimensions of the RAND-36 except the dimensions of physical function and general health, and in the AE-QoL except in the nutrition dimension (Table X). Patients who took sick leave due to HAE also had higher values in the AAS28 (median 40, range 869, $n=9$ ), compared with those who had taken no sick leave (median 0, range 0-27, $\mathrm{n}=27, \mathrm{p}<0.05)$. The number of days of sick leave due to HAE correlated with the AAS28 $\left(r_{\text {Spearman }}=0.64, \mathrm{p}<0.05\right)$. 
Table X. HR-QoL due to sick leave reported last four weeks. Sick leave: yes $n=9$ median age 46 range $20-70$, no $n=27$, median age 26 , range $26-79$ years. Data in median and range. Numbers in bold denote $\mathrm{p}<0.05$.

\begin{tabular}{|c|c|c|c|}
\hline \multirow[b]{2}{*}{ Instrument } & \multirow[b]{2}{*}{ Dimension/score } & \multicolumn{2}{|c|}{ Sick leave } \\
\hline & & Yes $(n=9)$ & No $(n=27)$ \\
\hline EQ-5D-5L & Utility value & $0.71(0.10-1.00)$ & $0.88(0.55-1.00)$ \\
\hline \multirow[t]{9}{*}{ RAND-36 } & Physical function & $100(50-100)$ & $100(100-100)$ \\
\hline & Physical health & $0(0-100)$ & $100(0-100)$ \\
\hline & Emotional problems & $0(0-100)$ & $100(100-100)$ \\
\hline & Energy/fatigue & $40(40-40)$ & $70(10-100)$ \\
\hline & $\begin{array}{l}\text { Emotional well-be- } \\
\text { ing }\end{array}$ & $80(60-100)$ & $70(40-80)$ \\
\hline & Social functioning & $56.25(37.5-62.5)$ & $100(50-100)$ \\
\hline & Pain & $50(12.5-57.5)$ & $83.8(32.5-100)$ \\
\hline & General health & $50(25-75)$ & $75(25-100)$ \\
\hline & Health transition & $50(25-50)$ & $50(50-50)$ \\
\hline \multirow[t]{5}{*}{ AE-QoL } & Functioning & $46.9(12.5-100)$ & $6.25(0-56.25)$ \\
\hline & Fatigue/mood & $60(45-75)$ & $25(0-95)$ \\
\hline & Fears/shame & $62.5(29.2-83.3)$ & $33.3(0-75)$ \\
\hline & Nutrition & $25(0-50)$ & $6.25(0-87.5)$ \\
\hline & Total AE-QoL & $53.7(27.9-69.1)$ & $25.7(0-58.8)$ \\
\hline
\end{tabular}




\section{Discussion}

In these studies, we have investigated HAE in Sweden concerning prevalence, clinical manifestations, sexual differences, treatments and HR-QoL in adults and children.

\section{Prevalence, demographics}

In study I, we registered a minimal prevalence of HAE in Sweden of 1.54/100,000, which is comparable with other European studies, e.g. 1.09/100,000 in Spain, $1.41 / 100,000$ in Denmark and $1.54 / 100,000$ in Italy (1-3). Other studies, for example from Taiwan, Japan and Brazil, have discovered too few patients in comparison to the number of inhabitants in their countries, so these reports cannot be used for comparison (43-45). HAE type I was much more prevalent in Sweden than type II (93\% vs 7\%), which is in line with the Danish findings (2). Elsewhere, type I represents around $85 \%$ of patients with HAE: for example, in Italy Zanichelli et al. found 87\% type I and 13\% type II. It seems that the pattern in Scandinavia is slightly different, probably due to background genetics $(2,3,42)$.

That HAE can be fatal is well-known to many families with HAE, which is also the case in Sweden, where 116 of 133 adults and in families 10 of 29 children were aware of ancestors that have died of HAE.

\section{Time to diagnosis, age at onset}

In study I, we identified a diagnostic delay of in median 10 years among the Swedish adults. To compare with other studies, we also calculated the mean diagnostic delay, with a result of 12.3 years. In Bygum's study, this was 16.3 years for the entire Danish cohort, and the more recently diagnosed patients in Denmark had a diagnostic delay of 10.3 years (2). Zanichelli et al. studied $150 \mathrm{HAE}$ patients from six European countries and detected an overall median diagnostic delay of 8.5 years, with the shortest delay in Germany and the longest in Italy (two vs. 15 years) (128). In Sweden, the time to diagnosis is comparable to the rest of Europe. Diagnostic delay in Sweden can be explained by the rarity of the disease, or to symptoms being mistaken for other more common diseases, such as histaminergic angioedema, and acute abdominal illnesses, or even irritable bowel syndrome. Some older patients could not be diagnosed until the biochemical methods for diagnosing HAE were available.

The onset of HAE symptoms found in study II among 23 symptomatic children was four years in median or 4.6 years in mean, which is lower than in other studies, where it varies in mean between 6.6 to 11.2 years (129-131). Martinez-Saguer et al. found a similar median age at onset as in our study: 4.4 years (132). The definitive median age of onset in this group of children is uncertain until all children have started to have symptoms, which makes comparisons with other studies difficult. The median age for diagnosis of children, which was three years, was lower than the median age of the onset of symptoms at four years. The reason for this was probably that all the children had 
a family history of HAE and many of them were therefore screened at an early age. Among adults, the median age at onset was 12 years. The differences in age at onset of symptoms between adults and children in studies I and II could be due more to recall bias among the adults than to actual differences between adults and children.

\section{Clinical manifestations}

In study I, the adult patients' prodromes showed not only the typical rash of HAE known as erythema marginatum; just as common were tiredness, altered mental state and physical sensations. Only $68 \%$ described prodromes in study I, slightly less than in three other studies which found estimates between $71 \%$ and $82.5 \%$ (133-135). The discrepancy may be explained by recall bias.

Forty-seven percent of our adult patients had more than 12 attacks in the previous year (Figure 5). According to Cicardi et al., one could consider long-term prophylaxis if the patient has more than 12 attacks a year, and this could imply that many of the adult Swedish patients were being undertreated in relation to long-term prophylaxis at the time of study I (73). Because of the retrospective nature of that study, we did not assess the severity of the individual HAE attacks, which would have required a prospective design.

Factors that triggered attacks among adults in study I were mostly trauma, mental stress, infections, physical exertion and, in females, menstruation. Among the children in study II, we identified that trauma and sporting activities were the most common triggers for skin swelling, whereas psychological stress, though difficult to specifically define, was the most common trigger for abdominal attacks. Zotter et al. have described similar triggers (62). To our knowledge, psychological stress had not previously been reported as such a common trigger for abdominal attacks among children. Furthermore, previously relatively, unknown triggers among the adults with HAE were reportedly alcohol and low air temperature, which could trigger an attack in $4 \%$ and $3 \%$ of patients, respectively.

For both adults in study I and children in study II, the two most common locations for attacks were the skin, and the abdomen, which is in line with earlier findings $(2,47,51)$.

During HAE attacks, up to $43 \%$ of our adult patients experienced itching. However, the angioedema of HAE is often referred to as non-pruritic in the literature (42). Although itching is a subjective sensation, we would expect patients to be able to differentiate itching from the tingling and/or painful sensation of skin swelling. Bradykinin is wellknown for generating pain, but its role in creating itching is less clear. In inflamed skin, such as in that of patients with atopic dermatitis, bradykinin can induce pruritus (136). In experimental mouse models, bradykinin has been shown to induce scratching behaviour (137). If patients with HAE have red skin lesions together with itching, this might be misinterpreted as urticaria. Therefore, wheals on the skin should always be checked to differentiate HAE from histaminergic angioedema. The itching of the skin in patients with HAE needs to be investigated further. 


\section{Treatments}

PdC1INH was the best treatment for acute attacks compared with tranexamic acid or attenuated androgens, for example. Tranexamic acid had poor to no effect on all patients during an acute attack. Icatibant was not yet available in Sweden at the time of studies I and II. We found that during laryngeal attacks, 26\% of our patients, a substantial proportion, had received glucocorticoids and $14 \%$ had also received antihistamines, although these drugs are likely to be ineffective in HAE. These treatments may have been used because the diagnosis was unknown, or if the diagnosis was known, because the treating physician lacked appropriate knowledge. Because of the high risk of recall bias, we did not differentiate between treatments given before and after the diagnosis was established. As for long-term prophylaxis, attenuated androgens seem to be as effective as pdC1INH. At the time of the study only seven patients had pdC1INH infusions regularly for maintenance treatment, as compared to 24 patients receiving attenuated androgens. In general, tranexamic acid did not reduce the number or severity of HAE attacks. In the WAO guidelines, tranexamic acid is not recommended as a maintenance treatment, although it is also stated that it can have an effect on some patients (34). During recent years, i.e. after the completion of the study I, there has been a paradigm shift in the treatment of adults with HAE, as revealed by Bygum (138). For example, more than half of the Danish patients with HAE stopped long-term prophylaxis with danazol or tranexamic acid and changed their treatment regimen to on-demand treatment with pdC1INH or icatibant (138). This fact highlights the need for a continuous prospective follow-up of patients with HAE, and documentation of data in national quality registries.

In children, only nine of the 23 who had symptoms of HAE in study II had been treated with pdC1INH, which was the only available treatment for HAE attacks at the time for children. In 2012 a new recommendation came that all attacks should be considered for treatment (73).

\section{Sick leave and hospital visits}

The adult patients in study I took between five and 10 days of sick leave yearly and made frequent visits to the hospital. That is a burden for the patient, the health care system and society, as has been shown in earlier studies $(99,139)$. The parents of $73 \%$ of the children with manifest HAE in study II had taken parental leave due to their children's HAE symptoms, and the economic and social impact on these families was probably substantial (139).

\section{Differences between males and females and reproductive health in females}

Among adults in study I, females were shown to have more frequent HAE attacks and more total sick days per year than males, which is similar to other reports $(47,63,66)$. During pregnancy and treatment with oestrogen-containing contraceptives, study I 
showed that females had more symptoms of HAE, which is also well-known $(47,66)$. According to our study, contraceptives containing only gestagens, and intra-uterine contraceptive devices in general, did not influence the disease course. These contraceptives are also recommended in females with HAE (66). In some females, gestagens can also work as a prophylaxis against HAE attacks (66). Only one patient had experienced an HAE attack during delivery. Thus, women with HAE and their physicians should not be too worried about HAE attacks during vaginal delivery. Therefore, the recommendation is that during vaginal delivery there is no need for prophylaxis, but that acute treatment for HAE should always be available $(63,66)$.

The rate of caesarean section in this population was $21 \%$. In Sweden in 2013, the average prevalence of caesarean section was $17 \%$, so it seems that this procedure is not significantly more frequent in our population than among others (140).

\section{HR-QoL in HAE}

\section{Adults}

\section{Disease activity and HR-QoL}

Higher attack frequency decreased HR-QoL between attacks in study III, as in study IV, where patients had more impairment in HR-QoL in almost all dimensions of the RAND-36 and AE-QoL, with elevated values on the AAS28 (Table VIII).

Correlation between VAS score of EQ-5D-5L and AAS28 was higher than the utility value of EQ-5D-5L and AAS28 (Table IX). The reason could be that the utility value is dependent on third-party assessment of the patient's health profile, while the VAS score is a subjective estimate of a patient's health (107).

Disease activity measured with the AAS28 correlated strongly with the pain dimension of the RAND-36, the functioning dimension of the AE-QoL and the total AE-QoL (Table IX). This confirms the findings from our prior study and those from the study carried out by Caballero et al., which showed that a higher attack frequency has a negative impact on HR-QoL (141). The patients reporting sick leave also had lower HR-QoL, confirming that the disease activity impairs HR-QoL. In line with this, patients who took sick leave also had higher AAS28 scores.

This provides further information about when to start prophylactic treatment. There are several recommendations available about attack frequency: for example, The Hereditary Angioedema International Working Group, as well as Craig et al, have suggested starting prophylaxis if there are more than 12 attacks per year $(73,142)$. Bowen et al. state that one could consider long-term prophylaxis if patients have more than one severe attack a month (42). The WAO guideline does not mention any attack frequency, but does state that one should consider patient quality of life among other things when assessing the need for prophylaxis (34).

Despite AAS28 reports disease activity and not only the number of attacks of angioedema, the differences between correlations of AAS28 or number of days with attacks 
and the HR-QoL instruments were insignificant in our study (Table IX). AAS28 allows the patients to evaluate the influence of these attacks on physical burden, daily activity and outward appearance, which can further describe the personal attack burden (112). However, in study IV, the number of attack days can explain almost as much of the impairment in HR-QoL as AAS28.

\section{Comparison with other diseases and normal population}

In other chronic diseases characterised by paroxysmal attacks, such as asthma and migraine, the EQ-5D values between attacks in controlled asthma or migraine have been 0.86 and 0.87 , respectively. In a Swedish study using a representative sample of the population in Stockholm mean EQ-5D index value ranged from 0.89 (20-29 years) to 0.74 (80-88 years). In comparison, in study III, the EQ-5D-5L for our patients with HAE was 0.83 , while in study IV, the EQ-5D-5L, which is comparable to EQ5D today, was $0.77(143-145)$.

\section{Differences between HR-QoL instruments}

In study IV we found that the impairment in all dimensions of the three HR-QoL instruments (EQ-5D-5L, RAND-36 and AE-QoL) overlaps, except the fears/shame dimension in the AE-QoL, which is obvious, because the AE-QoL instrument is intended for patients with angioedema and explores fears in relation to angioedema, whereas the other two do not include fear. The fears/shame dimension of the AE-QoL was also the dimension that correlated the least with the EQ-5D-5L and the dimensions of the RAND-36 (Table VII).

The dimensions of the EQ-5D-5L and the AE-QoL that were among the most affected in our study were anxiety/depression and fatigue/mood, which is in agreement with Lumry et al., Caballero et al., Fouche et al., who showed that patients with HAE have problems with anxiety and depression $(99,141,146)$.

A vast majority of our patients with $\mathrm{HAE}, 86 \%$ of adults and $91 \%$ of children, reported pain in association with attacks irrespective of attack location in studies I and II. Pain is missing in the AE-QoL, but is covered by the EQ-5D-5L and RAND-36 (107, 109, 112). Thus, in painful HAE attacks, the AE-QoL will not capture this aspect of impairment in HR-QoL.

\section{Sex differences in HR-QoL}

In study I, females were shown to take significantly more sick leave than males. In study IV, patients on sick leave had a more impaired HR-QoL, implying that the females in study I were more affected by their HAE than the males. In study III, the results indicated that being female had a negative effect on EQ5D today scores. Study IV did not contradict this, but the differences were fewer than expected. In study IV, females had significantly more impaired HR-QoL in only the energy/fatigue and general health dimensions of the RAND-36, compared with males (Table VI). The disease activity measured with the AAS28 in study IV was not significantly different between 
the sexes. We did not see significant differences between the sexes in the EQ-5D-5L or in all dimensions of AE-QoL, even though females usually have more severe disease (66). The smaller differences than expected in study IV could be because the responding females were significantly older, 54 vs. 41 years, and probably had lower levels of sex hormones than those not responding (Table IV).

\section{Prophylactic pharmacotherapy, HR-QoL and disease activity}

In study IV, there was no significant difference in HR-QoL in patients who were on prophylactic pharmacotherapy compared with those who were not (Table VI). This could be because the AAS28 scores of patients with prophylaxis showed an equal disease activity compared with those without prophylaxis. Patients on androgens had lower AAS28 scores, but not significantly, than patients on either tranexamic acid or pdC1INH. Patients on androgens and pdC1INH reported more than 50\% reduction of annual attack rate in study I, implying that their HR-QoL should be better than we found in study IV. However, as we have not studied the HR-QoL in the patients before they started their prophylaxis we cannot say whether prophylaxis increase HR-QoL or not in Swedish patients. Greve et al. have found that prophylaxis with pdC1INH did increase HR-QoL (147).

\section{Children}

In study III, the children had significantly better HR-QoL than adults between attacks of HAE as shown on the EQ-5D-5L, and the children in study II also had a good QoL. The reason why children had better HR-QoL than adults in study III could be because children had fewer attacks yearly, according to the same study, even though the difference was not significant. Kind et al., also showed earlier that HR-QoL decreases with age (123).

\section{Strengths and weaknesses}

\section{Study 1}

The strength of study I is that the prevalence found in it indicates that we have made a census instead of a sample, although some subjects may not have been identified. In addition, we used a multidisciplinary approach, multimodal recruitment, and a physician's telephone interview for clarification of responses in the written questionnaire, and for discussing patients' personal matters and reflections. Another strength is that we used the same interviewer through the entire study, thereby increasing consistency in questioning and interpretation. A weakness of study I is that it is retrospective, with a risk of recall bias. Another limitation is that treatments have changed during recent years and new therapies, such as icatibant, were not covered in study I. 


\section{Study II}

The strength of our study was the high response rate (86\%), which covered most of the known population of Swedish paediatric patients with HAE type I/II. A weakness was that the study was retrospective, risking recall bias, and despite the high response rate, the number of patients included was small. In addition, the seven-grade QoL VAS and the five-grade scale that we used to measure the level of health have not been validated for use in HAE. As we used QoL questions in study II, it was difficult to compare with study III and IV, where HR-QoL questions were used. As stated earlier, QoL is a wider concept than HR-QoL $(104,105)$. In this study, the parents answered on the behalf of their children, which could introduce bias.

\section{Study III}

A strength of this study was that response rate was about $72 \%$ of the then-known HAE population including both children and adults. A weakness was that the EQ5D attack data was retrospectively collected, risking recall bias.

\section{Study IV}

The strength of study IV is that we used various instruments to evaluate HR-QoL in order to describe the influence of HAE on HR-QoL. This creates a more differentiated and comprehensive view than just using one instrument, as has been done in other studies $(113,115,148)$. Using Svensson's method, no major differences were observed between how the patients completed the instruments the first and second times (125127). We assume that this is an indication that the patients' health status was stable over a four-week period.

The weakness of the study is that only $48 \%$ of the adults responded, which may have introduced selection bias, and also that both female and male responders were significantly older than non-responders and more females than males responded (Table IV). Therefore, the influence of HAE on HR-QoL described here cannot be regarded as representative of the total adult Swedish population with HAE. Another weakness is that we could not use the HAE-QoL, since it was not available in Swedish $(111,149)$.

\section{Future aspects}

As new medications are available studies concerning clinical manifestations and treatment could be carried out again in Sweden (81). For example, oral kallikrein inhibitor can be available in a foreseeable future as presented by Aygören-Pürsün et al. in the $10^{\text {th }}$ C1-Inhibitor deficiency workshop in Hungary (150). Also, monoclonal antibody against kallikrein might be introduced in the future (151). Furthermore, different routes of administration (intravenous, subcutaneous and oral) of medication with different pharmaco-kinetics call for real life clinical follow-up (138).

Further studies using different HR-QoL instruments need to be carried out in children with HAE, as only the EQ-5D-5L has been used so far in Sweden, in study III. 
The use of the more disease-specific instrument HAE-QoL in Sweden could provide further knowledge about HAE in Sweden, which requires the translation into Swedish and validation of HAE-QoL in Sweden.

Wilson et al. have shown that the annual cost for an average patient with HAE in the USA is 42,000 US dollars, and Aygören-Pürsün et al. have shown (without giving a monetary value) that HAE presents a substantial socioeconomic burden in European countries $(139,152)$. Health-economy studies that estimate the cost of HAE in Sweden are lacking, and would be of importance when discussing the allocation of resources for the care of patients with HAE. The health care system in Sweden is regionalised and studies of differences between the regions in availability of HAE-specialists, willingness to use prophylaxis, and willingness to use expensive medication for HAE would be interesting to explore.

Further studies on co-morbidities in adults in comparison with matched controls could give further information on whether HAE increases the risk for other diseases, such as autoimmune diseases. It has been implied that HAE can increase the risk of autoimmune diseases (153), and one other study has shown that hypertension is the most common co-morbidity (154). Studies with matched controls could also give further information on the risk of using attenuated androgens. A study by Tse et al. has shown that androgen use in HAE increase the risk of co-morbidities, but if this is true, though difficult due to the diminished use, it would be of interest to study this in Sweden (155).

Studies with web-based registers and smartphone applications can register every attack, including medication and HR-QoL data, and it would be useful to follow the Swedish patients both in research and in daily clinical use. Smartphone applications are on the way and Kreiberg, at the tenth C1-inhibitor deficiency workshop, presented such an application, which has provided interesting information on Danish patients with HAE (150).

Finally, cooperation with the other Nordic countries and countries in Europe is needed to improve studies, for example, in HR-QoL. If more than one country is included in a study, it would perhaps be easier to locate enough patients to provide more valid findings than if the study was done in Sweden only. The Hereditary Angioedema Burden of Illness Study in Europe (HAE-BOIS) is a good example of European cooperation that has provided valuable information $(115,139,156)$. In addition, Nordic and European cooperation on web-based registries and smartphone applications would make implementation easier. 


\section{Conclusions}

1. The minimal prevalence of HAE type I and II in Sweden was $1.54 / 100,000$.

2. The proportion of HAE type I was $93 \%$, and type II was $7 \%$.

3. For adults, the median age at onset of symptoms was 12 years (range 0-50) and median age at diagnosis was 22 years (1-81). In children, the median age at onset of HAE symptoms was four years, i.e. lower than in previous studies, which emphasises the need for early diagnosis.

4. After the onset of HAE symptoms, $82 \%$ of adults usually had attacks affecting the skin, $78 \%$ the abdomen, $27 \%$ the larynx, 26\% the urogenital area, $20 \%$ the lips, and $6 \%$ the tongue. For children, the corresponding figures were $71 \%, 83 \%$, $4 \%, 17 \%, 13 \%$ and $0 \%$, respectively.

5. The median number of attacks in those having attacks the previous year was 14 in adults and six in children.

6. During the previous year, $47 \%$ of adults experienced at least 12 attacks, $21 \%$ 411 attacks, $11 \%$ 1-3 attacks, while $22 \%$ were asymptomatic. For children, the corresponding figures were $48 \%, 30 \%, 9 \%$, and $14 \%$, respectively.

7. Irrespective of location of the angioedema in adults, $66 \%$ reported severe pain, $11 \%$ moderate, $9 \%$ mild and $14 \%$ no pain in association with the attacks. In children with symptoms of HAE, the corresponding figures were $69 \%, 13 \%, 9 \%$ and $9 \%$, respectively.

8. Triggers factors were experienced in $95 \%$ of adults and $74 \%$ of children. Neither uncomplicated vaginal delivery nor vaccination were triggers.

9. Many parents had taken parental leave due to their child's HAE symptoms.

10. Adult females had approximately twice as many attacks as males in the previous year.

11. For acute treatment, pdC1INH was found in general to have a very good effect. For long-term prophylaxis, attenuated androgens and pdC1INH reduced the annual attack frequency by more than $50 \%$. Tranexamic acid rarely had any effect on acute attacks or as long-term prophylaxis.

12. The EQ-5D-5L, RAND-36 and AE-QoL can be used to measure HR-QoL in patients with HAE.

13. The health-related dimensions most affected among HAE patients were: pain/discomfort and anxiety/depression in the EQ-5D-5L; energy/fatigue, general health, health transition and pain in the RAND-36, and fears/shame and fatigue/mood in the AE-QoL. Adults with high disease activity according to AAS or number of days with HAE had lower HR-QoL in the EQ-5D-5L, RAND-36 and AE-QoL, and took more sick leave.

14. Children reported better HR-QoL, according to the EQ-5D-5L, than adults.

15. The AE-QoL is more disease-specific in HAE than the generic instruments EQ5D-5L and RAND-36. However, the latter highlights the pain aspect, whereas the AE-QoL does not.

16. Patients with high disease activity should thus be considered for more intensive treatment to improve their HR-QoL. 


\section{Acknowledgement}

I would like to send my gratitude to all who have supported me on this voyage on completing this thesis. Particular I would like to thank:

First of all, the patients and their relatives, without you there would have been no results at all! I am deeply grateful that you have taking the time and the effort to reply to all questionnaires.

Janne Björkander, my tutor and mentor, for guiding me and introducing me to this interesting world of HAE and research. I am also grateful for your patience, encouragement then needed and sharing of your vast experience and knowledge.

Carl-Fredrik Wahlgren, my co-tutor for your guidance, knowledge and experience.

Mats Nilsson my co-tutor for your knowledge in statistics and helping me getting the numbers right and the layout of the thesis.

Anders Lindfors, my co-author for your knowledge about children with HAE, valuable input and your ability to always finding calculations error.

Lotus Mallbris, my former co-tutor for your great effort in starting up this project by setting up the data-base and creating the questionnaires used in the first two studies.

Anders Nygren, co-author for your work with study II.

Simon Dawson, co-author for your work with study III.

Sonja Werner for being a member of the initial study group helping to recruit patients for the studies and valuable input.

All the other colleagues and staff in Sweden for your input and helping with recruiting patients.

All my colleagues at the Department of Internal Medicine, County Hospital of Ryhov, physicians, nurses and other for making it possible for me to have time for this project.

All my friends, I have not forgotten you all. Now I will have more time.

All my relatives, aunts, uncles, cousins and seconds cousins and all other. The summers in Björkhagen and Stadavik we have shared there will always be a fond memory.

My siblings with their families: Maria with Jörg, Milena and Maike, Hedvig with Werner and Emma and Jonas with Maria, Alexander, and Evelina for their love and always being there.

My father who inspired me to enter the world of medicine and science. I have always felt your support and love. 
My mother who unfortunately is not with us any longer. You still had time to help me with a couple of sentences in an abstract. Even though you are not with us any more I still can feel your love and support.

Funding for this thesis was provided by Futurum, Jönköping County Council, Jönköping; Karolinska Institutet, the Stockholm County Council, Stockholm; Linköping University, Linköping, Sweden. ViroPharma contributed in study III with nonmonetary funding to assist with data collection and statistical analysis. CSL Behring supported this thesis with an unrestricted grant. The company had no role in the planning or implementation of studies including data analysis and publishing. 


\section{References}

1. Roche O, Blanch A, Caballero T, Sastre N, Callejo D, Lopez-Trascasa M. Hereditary angioedema due to $\mathrm{C} 1$ inhibitor deficiency: patient registry and approach to the prevalence in Spain. Ann Allergy Asthma Immunol. 2005;94:498-503.

2. Bygum A. Hereditary angio-oedema in Denmark: a nationwide survey. $\mathrm{Br} \mathbf{J}$ Dermatol. 2009;161:1153-1158.

3. Zanichelli A, Arcoleo F, Barca M, Borrelli P, Bova M, Cancian M, et al. A nationwide survey of hereditary angioedema due to $\mathrm{C} 1$ inhibitor deficiency in Italy. Orphanet J Rare Dis. 2015;10:11.

4. Donati M. De medica historia mirabile. Mantua Osana. 1586:VII:Cap III:304.

5. Mai FA. Stolpertus, ein junger Arzt am Krankenbette: Schwann \& Götz, Mannheim; 1777.

6. Milton J. On giant urticaria. Edinb Med J. 1876;22:513-526.

7. Quincke H. Über akutes umschreibenes Hautödem. Monatshefte Prakt Dermatol. 1882;1882:129-131.

8. Strübing $\mathrm{P}$. Über acutes (angioneurotisches) Ödem. Zeitschr $\mathrm{F}$ Klin Med. 1885(9):381-396.

9. Osler W. Hereditary angioneurotic edema. Am J Med Sci. 1888;95:362-367.

10. Reshef A, Kidon M, Leibovich I. The Story of Angioedema: from Quincke to Bradykinin. Clin Rev Allergy Immunol. 2016;51:121-139.

11. Pensky J, Levy LR, Lepow IH. Partial purification of a serum inhibitor of C'1-esterase. J Biol Chem. 1961;236:1674-1679.

12. Donaldson VH, Evans RR. A Biochemical Abnormality in Herediatry Angioneurotic Edema: Absence of Serum Inhibitor of $C^{\prime}$ 1-Esterase. Am J Med. 1963;35:37-44.

13. Donaldson VH, Rosen FS. Action of Complement in Hereditary Angioneurotic Edema: The Role of C'1-Esterase. J Clin Invest. 1964;43:2204-2213.

14. Rosen FS, Pensky J, Donaldson V, Charache P. Hereditary Angioneurotic Edema: Two Genetic Variants. Science. 1965;148:957-958.

15. Bock SC, Skriver K, Nielsen E, Thogersen HC, Wiman B, Donaldson VH, et al. Human C1 inhibitor: primary structure, cDNA cloning, and chromosomal localization. Biochemistry. 1986;25:4292-4301.

16. Fields T, Ghebrehiwet B, Kaplan AP. Kinin formation in hereditary angioedema plasma: evidence against kinin derivation from $\mathrm{C} 2$ and in support of "spontaneous" formation of bradykinin. J Allergy Clin Immunol. 1983;72:54-60. 
17. Nussberger J, Cugno M, Amstutz C, Cicardi M, Pellacani A, Agostoni A. Plasma bradykinin in angio-oedema. Lancet. 1998;351:1693-1697.

18. Bork K, Barnstedt SE, Koch P, Traupe H. Hereditary angioedema with normal C1inhibitor activity in women. Lancet. 2000;356:213-217.

19. Binkley KE, Davis A, 3rd. Clinical, biochemical, and genetic characterization of a novel estrogen-dependent inherited form of angioedema. J Allergy Clin Immunol. 2000;106:546-550.

20. Dewald G, Bork K. Missense mutations in the coagulation factor XII (Hageman factor) gene in hereditary angioedema with normal $\mathrm{C} 1$ inhibitor. Biochem Biophys Res Commun. 2006;343:1286-1289.

21. Nussberger J, Cugno M, Cicardi M, Agostoni A. Local bradykinin generation in hereditary angioedema. J Allergy Clin Immunol. 1999;104:1321-1322.

22. Wang DZ, Chao L, Chao J. Hypotension in transgenic mice overexpressing human bradykinin B2 receptor. Hypertension. 1997;29:488-493.

23. Kayashima Y, Smithies O, Kakoki M. The kallikrein-kinin system and oxidative stress. Curr Opin Nephrol Hypertens. 2012;21:92-96.

24. Leeb-Lundberg LM, Marceau F, Muller-Esterl W, Pettibone DJ, Zuraw BL. International union of pharmacology. XLV. Classification of the kinin receptor family: from molecular mechanisms to pathophysiological consequences. Pharmacol Rev. 2005;57:27-77.

25. D'Orleans-Juste P, de Nucci G, Vane JR. Kinins act on B1 or B2 receptors to release conjointly endothelium-derived relaxing factor and prostacyclin from bovine aortic endothelial cells. Br J Pharmacol. 1989;96:920-926.

26. Bas M. Clinical efficacy of icatibant in the treatment of acute hereditary angioedema during the FAST-3 trial. Expert Rev Clin Immunol. 2012;8:707-717.

27. Bossi F, Fischetti F, Regoli D, Durigutto P, Frossi B, Gobeil F, Jr., et al. Novel pathogenic mechanism and therapeutic approaches to angioedema associated with $\mathrm{C} 1$ inhibitor deficiency. J Allergy Clin Immunol. 2009;124:1303-1310.

28. Zuraw BL, Christiansen SC. HAE Pathophysiology and Underlying Mechanisms. Clin Rev Allergy Immunol. 2016;51:216-229.

29. Dejana E, Tournier-Lasserve E, Weinstein BM. The control of vascular integrity by endothelial cell junctions: molecular basis and pathological implications. Dev Cell. 2009;16:209-21.

30. Oda H, Takeichi M. Evolution: structural and functional diversity of cadherin at the adherens junction. J Cell Biol. 2011;193:1137-1146.

31. Orsenigo F, Giampietro C, Ferrari A, Corada M, Galaup A, Sigismund S, et al. Phosphorylation of VE-cadherin is modulated by haemodynamic forces and contributes to the regulation of vascular permeability in vivo. Nat Commun. 2012;3:1208. 
32. Kaplan AP, Ghebrehiwet B. The plasma bradykinin-forming pathways and its interrelationships with complement. Mol Immunol. 2010;47:2161-2169.

33. Kaplan AP, Joseph K. The bradykinin-forming cascade and its role in hereditary angioedema. Ann Allergy Asthma Immunol. 2010;104:193-204.

34. Craig T, Aygören-Pürsün E, Bork K, Bowen T, Boysen H, Farkas H, et al. WAO Guideline for the Management of Hereditary Angioedema. World Allergy Organ J. 2012;5:182-199.

35. Kaplan AP. Enzymatic pathways in the pathogenesis of hereditary angioedema: the role of C1 inhibitor therapy. J Allergy Clin Immunol. 2010;126:918-925.

36. The Human Gene Mutation Database [Internet].Cardiff: Institute of Medical Genetics in Cardiff, Cardiff University (C2017. [cited 2017 sep 6] Available from:

http://www.hgmd.cf.ac.uk/ac/.

37. Pappalardo E, Cicardi M, Duponchel C, Carugati A, Choquet S, Agostoni A, et al. Frequent de novo mutations and exon deletions in the $\mathrm{Clinhibitor}$ gene of patients with angioedema. J Allergy Clin Immunol. 2000;106:1147-1154.

38. Bork K. Hereditary angioedema with normal C1 inhibitor activity including hereditary angioedema with coagulation factor XII gene mutations. Immunol Allergy Clin N Am. 2006;26:709-724.

39. Cicardi M, Zanichelli A. Acquired angioedema. Allergy Asthma Clin Immunol. 2010;6:14.

40. Bova M, Guilarte M, Sala-Cunill A, Borrelli P, Rizzelli GM, Zanichelli A. Treatment of ACEI-related angioedema with icatibant: a case series. Intern Emerg Med. 2015; $10: 345-350$

41. Zingale LC, Beltrami L, Zanichelli A, Maggioni L, Pappalardo E, Cicardi B, et al. Angioedema without urticaria: a large clinical survey. CMAJ. 2006;175:1065-1070.

42. Bowen T, Cicardi M, Farkas H, Bork K, Longhurst HJ, Zuraw B, et al. 2010 International consensus algorithm for the diagnosis, therapy and management of hereditary angioedema. Allergy Asthma Clin Immunol. 2010;6:24.

43. Lei WT, Shyur SD, Huang LH, Kao YH, Lo CY. Type I hereditary angioedema in Taiwan -- clinical, biological features and genetic study. Asian Pac J Allergy Immunol. 2011;29:327-331.

44. Iwamoto K, Mihara S, Ikezawa Z, Hide M. [National prevalence survey of hereditary angioedema in Japan]. Arerugi. 2011;60:26-32.

45. Grumach AS, Valle SO, Toledo E, de Moraes Vasconcelos D, Villela MM, Mansour E, et al. Hereditary angioedema: first report of the Brazilian registry and challenges. J Eur Acad Dermatol Venereol. 2013 Mar;27:338-344.

46. Frank MM, Gelfand JA, Atkinson JP. Hereditary angioedema: the clinical syndrome and its management. Ann Intern Med. 1976;84:580-593. 
47. Bork K, Meng G, Staubach P, Hardt J. Hereditary angioedema: new findings concerning symptoms, affected organs, and course. Am J Med. 2006;119:267-274.

48. Bork K, Barnstedt SE. Laryngeal edema and death from asphyxiation after tooth extraction in four patients with hereditary angioedema. J Am Dent Assoc. 2003;134:108894.

49. Bork K, Hardt J, Witzke G. Fatal laryngeal attacks and mortality in hereditary angioedema due to C1-INH deficiency. J Allergy Clin Immunol. 2012;130:692-697.

50. Bork K, Siedlecki K, Bosch S, Schopf RE, Kreuz W. Asphyxiation by laryngeal edema in patients with hereditary angioedema. Mayo Clin Proc. 2000;75:349-354.

51. Bork K, Staubach P, Eckardt AJ, Hardt J. Symptoms, course, and complications of abdominal attacks in hereditary angioedema due to $\mathrm{C} 1$ inhibitor deficiency. Am $\mathrm{J}$ Gastroenterol. 2006;101:619-627.

52. Kaplan AP, Greaves MW. Angioedema. J Am Acad Dermatol. 2005;53:373-388; quiz 389-392.

53. Longhurst HJ, Bork K. Hereditary angioedema: causes, manifestations and treatment. Br J Hosp Med. 2006;67:654-657.

54. Killedar MM, Malani AS. Hereditary angioedema-presenting as recurrent abdominal pain. Indian J Surg. 2011;73:444-446.

55. Testori A, Melamed I. Manifestations of hereditary angioedema. Ann Allergy Asthma Immunol. 2017;118:119-120.

56. Prematta MJ, Bewtra AK, Levy RJ, Wasserman RL, Jacobson KW, Machnig T, et al. Per-attack reporting of prodromal symptoms concurrent with $\mathrm{C} 1$-inhibitor treatment of hereditary angioedema attacks. Adv Ther. 2012;29:913-922.

57. Starr JC, Brasher GW. Erythema marginatum preceding hereditary angioedema. J Allergy Clin Immunol. 1974;53:352-355.

58. Starr JC, Brasher GW, Rao A, Posey D. Erythema marginatum and hereditary angioedema. South Med J. 2004;97:948-50.

59. Saito M, Hatakeyama S. Acute Rheumatic Fever with Erythema Marginatum. N Engl J Med. 2016;375:2480.

60. Farkas H, Harmat G, Fay A, Fekete B, Karadi I, Visy B, et al. Erythema marginatum preceding an acute oedematous attack of hereditary angioneurotic oedema. Acta Derm Venereol. 2001;81:376-377.

61. Rasmussen ER, de Freitas PV, Bygum A. Urticaria and Prodromal Symptoms Including Erythema Marginatum in Danish Patients with Hereditary Angioedema. Acta Derm Venereol. 2016;96:373-376. 
62. Zotter Z, Csuka D, Szabo E, Czaller I, Nebenfuhrer Z, Temesszentandrasi G, et al. The influence of trigger factors on hereditary angioedema due to $\mathrm{C} 1$-inhibitor deficiency. Orphanet J Rare Dis. 2014;9:44.

63. Bouillet L, Gompel A. Hereditary angioedema in women: specific challenges. Immunol Allergy Clin North Am. 2013;33:505-511.

64. Cicardi M, Zanichelli A. The acquired deficiency of C1-inhibitor: lymphoproliferation and angioedema. Curr Mol Med. 2010;10:354-360.

65. Agostoni A, Cicardi M, Cugno M, Zingale LC, Gioffre D, Nussberger J. Angioedema due to angiotensin-converting enzyme inhibitors. Immunopharmacology. 1999;44:21-25.

66. Caballero T, Farkas H, Bouillet L, Bowen T, Gompel A, Fagerberg C, et al. International consensus and practical guidelines on the gynecologic and obstetric management of female patients with hereditary angioedema caused by $\mathrm{C} 1$ inhibitor deficiency. J Allergy Clin Immunol. 2012;129:308-20.

67. Karim Y, Griffiths H, Deacock S. Normal complement C4 values do not exclude hereditary angioedema. J Clin Pathol. 2004;57:213-214.

68. Longhurst H, Cicardi M. Hereditary angio-oedema. Lancet. 2012;379:474-481.

69. Zingale LC, Castelli R, Zanichelli A, Cicardi M. Acquired deficiency of the inhibitor of the first complement component: presentation, diagnosis, course, and conventional management. Immunol Allergy Clin North Am. 2006;26:669-690.

70. Atkinson JP. Diagnosis and management of hereditary angioedema (HAE). Ann Allergy. 1979;42(6):348-352.

71. Nilsson IM, Andersson L, Bjorkman SE. Epsilon-aminocaproic acid (E-ACA) as a therapeutic agent based on 5 year's clinical experience. Acta Med Scand Suppl. 1966;448:1-46.

72. Blohme G. Treatment of hereditary angioneurotic oedema with tranexamic acid. A random double-blind cross-over study. Acta Med Scand. 1972;192:293-298.

73. Cicardi M, Bork K, Caballero T, Craig T, Li HH, Longhurst H, et al. Evidencebased recommendations for the therapeutic management of angioedema owing to hereditary $\mathrm{C} 1$ inhibitor deficiency: consensus report of an International Working Group. Allergy. 2012;67:147-157.

74. Pickering RJ, Good RA, Kelly JR, Gewurz H. Replacement therapy in hereditary angioedema. Successful treatment of two patients with fresh frozen plasma. Lancet. 1969;1:326-330.

75. Brackertz D, Kueppers F. Possible therapy in hereditary angioneurotic edema (HAE). Klin Wochenschr. 1973;51:620-622. 
76. Zuraw BL, Busse PJ, White M, Jacobs J, Lumry W, Baker J, et al. Nanofiltered C1 inhibitor concentrate for treatment of hereditary angioedema. N Engl J Med.

2010;363:513-522.

77. Zuraw B, Cicardi M, Levy RJ, Nuijens JH, Relan A, Visscher S, et al. Recombinant human C1-inhibitor for the treatment of acute angioedema attacks in patients with hereditary angioedema. J Allergy Clin Immunol. 2010;126:821-827.

78. Longhurst $\mathrm{H}$. Rhucin, a recombinant $\mathrm{C} 1$ inhibitor for the treatment of hereditary angioedema and cerebral ischemia. Curr Opin Investig Drugs. 2008;9:310-323.

79. Cicardi M, Banerji A, Bracho F, Malbran A, Rosenkranz B, Riedl M, et al. Icatibant, a new bradykinin-receptor antagonist, in hereditary angioedema. $\mathrm{N}$ Engl $\mathrm{J}$ Med. 2010;363:532-541.

80. Sheffer AL, Campion M, Levy RJ, Li HH, Horn PT, Pullman WE. Ecallantide (DX88) for acute hereditary angioedema attacks: integrated analysis of 2 double-blind, phase 3 studies. J Allergy Clin Immunol. 2011;128:153-9.

81. Longhurst H, Cicardi M, Craig T, Bork K, Grattan C, Baker J, et al. Prevention of Hereditary Angioedema Attacks with a Subcutaneous C1 Inhibitor. N Engl J Med. 2017;376:1131-40.

82. Longhurst HJ, Farkas H, Craig T, Aygören-Pürsün E, Bethune C, Björkander J, et al. HAE international home therapy consensus document. Allergy Asthma Clin Immunol. 2010;6:22.

83. Aygören-Pürsün E, Martinez-Saguer I, Rusicke E, Klingebiel T, Kreuz W. On demand treatment and home therapy of hereditary angioedema in Germany - the Frankfurt experience. Allergy Asthma Clin Immunol. 2010;6:21.

84. Krassilnikova S, Craig ET, Craig TJ. Summary of the International Multicenter Prospective Angioedema C1-inhibitor Trials 1 and 2 (IMPACT1 and 2) Expert Rev Clin Immunol. 2010;6:327-334.

85. Lyseng-Williamson KA. Nanofiltered human $\mathrm{C} 1$ inhibitor concentrate (Cinryze $(\mathrm{R}))$ : in hereditary angioedema. BioDrugs. 2011;25:317-327.

86. Plosker GL. Recombinant human $\mathrm{c} 1$ inhibitor (conestat alfa): in the treatment of angioedema attacks in hereditary angioedema. BioDrugs. 2012;26:315-323.

87. Riedl MA, Levy RJ, Suez D, Lockey RF, Baker JW, Relan A, et al. Efficacy and safety of recombinant $\mathrm{C} 1$ inhibitor for the treatment of hereditary angioedema attacks: a North American open-label study. Ann Allergy Asthma Immunol. 2013;110:295-299.

88. Riedl M. Recombinant human C1 esterase inhibitor in the management of hereditary angioedema. Clin Drug Investig. 2015;35:407-417.

89. Cicardi M, Mannucci PM, Castelli R, Rumi MG, Agostoni A. Reduction in transmission of hepatitis $\mathrm{C}$ after the introduction of a heat-treatment step in the production of C1-inhibitor concentrate. Transfusion. 1995;35:209-212. 
90. Groner A, Nowak T, Schafer W. Pathogen safety of human C1 esterase inhibitor concentrate. Transfusion. 2012;52(10):2104-12.

91. Lehmann A. Ecallantide (DX-88), a plasma kallikrein inhibitor for the treatment of hereditary angioedema and the prevention of blood loss in on-pump cardiothoracic surgery. Expert Opin Biol Ther. 2008;8:1187-1199.

92. Levy RJ, Lumry WR, McNeil DL, Li HH, Campion M, Horn PT, et al. EDEMA4: a phase 3, double-blind study of subcutaneous ecallantide treatment for acute attacks of hereditary angioedema. Ann Allergy Asthma Immunol. 2010;104:523-529.

93. Farkas H, Martinez-Saguer I, Bork K, Bowen T, Craig T, Frank M, et al. International consensus on the diagnosis and management of pediatric patients with hereditary angioedema with C1 inhibitor deficiency. Allergy. 2017;72:300-313.

94. Cugno M, Cicardi M, Agostoni A. Activation of the contact system and fibrinolysis in autoimmune acquired angioedema: a rationale for prophylactic use of tranexamic acid. J Allergy Clin Immunol. 1994;93:870-876.

95. Gelfand JA, Sherins RJ, Alling DW, Frank MM. Treatment of hereditary angioedema with danazol. Reversal of clinical and biochemical abnormalities. N Engl J Med. 1976;295:1444-1448.

96. Agostoni A, Cicardi M, Martignoni GC, Bergamaschini L, Marasini B. Danazol and stanozolol in long-term prophylactic treatment of hereditary angioedema. J Allergy Clin Immunol. 1980;65:75-79.

97. Bork K. Current management options for hereditary angioedema. Curr Allergy Asthma Rep. 2012;12:273-280.

98. Gompels MM, Lock RJ. Cinryze (C1-inhibitor) for the treatment of hereditary angioedema. Expert Rev Clin Immunol. 2011;7:569-573.

99. Lumry WR, Castaldo AJ, Vernon MK, Blaustein MB, Wilson DA, Horn PT. The humanistic burden of hereditary angioedema: Impact on health-related quality of life, productivity, and depression. Allergy Asthma Proc. 2010;31:407-414.

100. World Health Organization, Constitution of the World health Organization. Chronicle of the World health Organization, vol 1. 1947, Geneva: World health Organization.

101. Huber M, Knottnerus JA, Green L, van der Horst H, Jadad AR, Kromhout D, et al. How should we define health? Bmj. 2011;343:4163.

102. Nordenfelt L. Livskvalitet och hälsa: teori \& kritik. 2. uppl. Linköping: Univ., Institutionen för hälsa och samhälle; 2004.

103. Farquhar M. Definitions of quality of life: a taxonomy. J Adv Nurs. 1995;22:502508 . 
104. Hobman TC, Woodward L, Farquhar MG. Targeting of a heterodimeric membrane protein complex to the Golgi: rubella virus E2 glycoprotein contains a transmembrane Golgi retention signal. Mol Biol Cell. 1995;6:7-20.

105. Ferrans CE, Zerwic JJ, Wilbur JE, Larson JL. Conceptual model of health-related quality of life. J Nurs Scholarsh. 2005;37:336-42.

106. Anderson KL, Burckhardt CS. Conceptualization and measurement of quality of life as an outcome variable for health care intervention and research. J Adv Nurs. 1999;29(2):298-306.

107. Herdman M, Gudex C, Lloyd A, Janssen M, Kind P, Parkin D, et al. Development and preliminary testing of the new five-level version of EQ-5D (EQ-5D-5L). Qual Life Res. 2011;20:1727-36.

108. Ware JE, Jr., Sherbourne CD. The MOS 36-item short-form health survey (SF-36). I. Conceptual framework and item selection. Med Care. 1992;30(6):473-83.

109. Hays RD, Sherbourne CD, Mazel RM. The RAND 36-Item Health Survey 1.0. Health Econ. 1993;2:217-227.

110. Weller K, Groffik A, Magerl M, Tohme N, Martus P, Krause K, et al. Development and construct validation of the angioedema quality of life questionnaire. Allergy. 2012;67:1289-1298.

111. Prior N, Remor E, Perez-Fernandez E, Caminoa M, Gomez-Traseira C, Gaya F, et al. Psychometric Field Study of Hereditary Angioedema Quality of Life Questionnaire for Adults: HAE-QoL. J Allergy Clin Immunol Pract. 2016;4:464-473.

112. Weller K, Groffik A, Magerl M, Tohme N, Martus P, Krause K, et al. Development, validation, and initial results of the Angioedema Activity Score. Allergy. 2013;68:1185-1192.

113. Gomide MA, Toledo E, Valle SO, Campos RA, Franca AT, Gomez NP, et al. Hereditary angioedema: quality of life in Brazilian patients. Clinics (Sao Paulo).2013;68:81-83.

114. Jindal NL, Harniman E, Prior N, Perez-Fernandez E, Caballero T, Betschel S. Hereditary angioedema: health-related quality of life in Canadian patients as measured by the SF-36. Allergy Asthma Clin Immunol. 2017;13:4.

115. Aygören-Pürsün E, Bygum A, Beusterien K, Hautamaki E, Sisic Z, Boysen HB, et al. Estimation of EuroQol 5-Dimensions health status utility values in hereditary angioedema. Patient Prefer Adherence. 2016;10:1699-1707.

116. Weller K, Maurer M, Fridman M, Supina D, Schranz J, Magerl M. Health-related quality of life with hereditary angioedema following prophylaxis with subcutaneous C1inhibitor with recombinant hyaluronidase. Allergy Asthma Proc. 2017;38:143-151.

117. Read N, Lim E, Tarzi MD, Hildick-Smith P, Burns S, Fidler KJ. Paediatric hereditary angioedema: a survey of UK service provision and patient experience. Clin Exp Immunol. 2014;178:483-488. 
118. Engel-Yeger B, Farkas H, Kivity S, Veszeli N, Kohalmi KV, Kessel A. Health-related quality of life among children with hereditary angioedema. Pediatr Allergy Immunol. 2017 Jun;28:370-376.

119. Blohme G, Ysander L, Korsan-Bengtsen K, Laurell AB. Hereditary angioneurotic oedema in three families. Symptomatic heterogeneity, complement analysis and therapeutic trials. Acta Med Scand. 1972;191:209-219.

120. Nilsson SE, Floderus S. Nine Cases of Hereditary and Non-Hereditary Periodic Diseases. Acta Med Scand.1964;175:341-6.

121. Mallbris L, Nordenfelt P, Björkander J, Lindfors A, Werner S, Wahlgren CF. The establishment and utility of Sweha-Reg: a Swedish population-based registry to understand hereditary angioedema. BMC Dermatol. 2007;7:6.

122. Harrison MJ, Lunt M, Verstappen SM, Watson KD, Bansback NJ, Symmons DP. Exploring the validity of estimating EQ-5D and SF-6D utility values from the health assessment questionnaire in patients with inflammatory arthritis. Health Qual Life Outcomes. 2010;8:21.

123. Kind P, Dolan P, Gudex C, Williams A. Variations in population health status: results from a United Kingdom national questionnaire survey. Bmj. 1998;316:736-41.

124. Burström K, Sun S, Gerdtham UG, Henriksson M, Johannesson M, Levin LA, et al. Swedish experience-based value sets for EQ-5D health states. Qual Life Res. 2014;23: 431-42.

125. Avdic A, Svensson E. Svenssons method 1.1 ed. Örebro 2010 Interactive software supporting Svenssons method. Accessed from http://avdic.se/svenssonsmetod.html 2017-04-14.

126. Svensson E, Holm S. Separation of systematic and random differences in ordinal rating scales. Stat Med. 1994;13:2437-53.

127. Svensson E. Concordance between ratings using different scales for the same variable. Stat Med. 2000;19(24):3483-96.

128. Zanichelli A, Magerl M, Longhurst H, Fabien V, Maurer M. Hereditary angioedema with $\mathrm{C} 1$ inhibitor deficiency: delay in diagnosis in Europe. Allergy Asthma Clin Immunol. 2013;9:29.

129. Farkas H. Pediatric hereditary angioedema due to C1-inhibitor deficiency. Allergy Asthma Clin Immunol. 2010;6:18.

130. Bork K, Meng G, Staubach P, Hardt J. Hereditary angioedema: new findings concerning symptoms, affected organs, and course. Am J Med. 2006;119:267-274.

131. Bygum A. Hereditary angio-oedema in Denmark: a nationwide survey. $\mathrm{Br} \mathbf{J}$ Dermatol. 2009;161:1153-1158. 
132. Martinez-Saguer I, Rusicke E, Aygören-Pürsün E, Klingebiel T, Kreuz W. Clinical Surveillance Program Of Pediatric Hereditary Angioedema (HAE) Patients Undergoing Home Treatment. J Allergy Clin Immunol. 2009;123:S116.

133. Reshef A, Prematta MJ, Craig TJ. Signs and symptoms preceding acute attacks of hereditary angioedema: results of three recent surveys. Allergy Asthma Proc. 2013;34(3):261-266.

134. Prematta MJ, Bewtra AK, Levy RJ, Wasserman RL, Jacobson KW, Machnig T, et al. Per-attack reporting of prodromal symptoms concurrent with $\mathrm{C} 1$-inhibitor treatment of hereditary angioedema attacks. Adv Ther. 2012;29:913-922.

135. Magerl M, Doumoulakis G, Kalkounou I, Weller K, Church MK, Kreuz W, et al. Characterization of prodromal symptoms in a large population of patients with hereditary angio-oedema. Clin Exp Dermatol. 2014;39:298-303.

136. Hosogi M, Schmelz M, Miyachi Y, Ikoma A. Bradykinin is a potent pruritogen in atopic dermatitis: a switch from pain to itch. Pain. 2006;126:16-23.

137. Costa R, Manjavachi MN, Motta EM, Marotta DM, Juliano L, Torres HA, et al. The role of kinin B1 and B2 receptors in the scratching behaviour induced by proteinase-activated receptor-2 agonists in mice. Br J Pharmacol. 2010;159:888-897.

138. Bygum A. Hereditary angioedema - consequences of a new treatment paradigm in Denmark. Acta Derm Venereol. 2014;94:436-441.

139. Aygören-Pürsün E, Bygum A, Beusterien K, Hautamaki E, Sisic Z, Wait S, et al. Socioeconomic burden of hereditary angioedema: results from the hereditary angioedema burden of illness study in Europe. Orphanet J Rare Dis. 2014;9:99.

140. Sverige. Socialstyrelsen. Graviditeter, förlossningar och nyfödda barn: medicinska födelseregistret 1973-2013, assisterad befruktning 1991-2012. Stockholm: Socialstyrelsen; 2014.

141. Caballero T, Aygören-Pürsün E, Bygum A, Beusterien K, Hautamaki E, Sisic Z, et al. The humanistic burden of hereditary angioedema: Results from the Burden of Illness Study in Europe. Allergy Asthma Proc. 2013;35:47-53.

142. Craig T, Riedl M, Dykewicz MS, Gower RG, Baker J, Edelman FJ, et al. When is prophylaxis for hereditary angioedema necessary? Ann Allergy Asthma Immunol. 2009; 102:366-372.

143. Allegra L, Cremonesi G, Girbino G, Ingrassia E, Marsico S, Nicolini G, et al. Reallife prospective study on asthma control in Italy: cross-sectional phase results. Respir Med. 2012;106:205-214.

144. Stafford MR, Hareendran A, Ng-Mak DS, Insinga RP, Xu R, Stull DE. EQ-5Dderived utility values for different levels of migraine severity from a UK sample of migraineurs. Health Qual Life Outcomes. 2012;10:65.

145. Burström K, Johannesson M, Diderichsen F. Swedish population health-related quality of life results using the EQ-5D. Qual Life Res. 2001;10:621-635. 
146. Fouche AS, Saunders EF, Craig T. Depression and anxiety in patients with hereditary angioedema. Ann Allergy Asthma Immunol. 2014;112:371-375.

147. Greve J, Hahn J, Nordmann M, Schuler PJ, Bas M, Hoffmann TK, et al. Nanofiltrated $\mathrm{C} 1$-esterase-inhibitor in the prophylactic treatment of bradykinin-mediated angioedema. Transfusion. 2016;56:1022-1029.

148. Aabom A, Andersen KE, Perez-Fernandez E, Caballero T, Bygum A. Healthrelated quality of life in Danish patients with hereditary angioedema. Acta Derm Venereol. 2015;95:225-226.

149. Prior N, Remor E, Gomez-Traseira C, Lopez-Serrano C, Cabanas R, Contreras J, et al. Development of a disease-specific quality of life questionnaire for adult patients with hereditary angioedema due to $\mathrm{C} 1$ inhibitor deficiency (HAE-QoL): Spanish multi-centre research project. Health Qual Life Outcomes. 2012;10:82.

150. Schmaier AH, Cicardi M, Reshef A, Moldovan D, Mócsai A, López-Trascasa M, et al. Abstracts from the 10th C1-inhibitor deficiency workshop. Allergy Asthma Clin Immunol 2017;13:29.

151. Banerji A, Busse P, Shennak M, Lumry W, Davis-Lorton M, Wedner HJ, et al. Inhibiting Plasma Kallikrein for Hereditary Angioedema Prophylaxis. N Engl J Med. 2017;376:717-728.

152. Wilson DA, Bork K, Shea EP, Rentz AM, Blaustein MB, Pullman WE. Economic costs associated with acute attacks and long-term management of hereditary angioedema. Ann Allergy Asthma Immunol. 2010;104:314-320.

153. Kessel A, Peri R, Perricone R, Guarino MD, Vadasz Z, Novak R., et al. The autoreactivity of $\mathrm{B}$ cells in hereditary angioedema due to $\mathrm{C} 1$ inhibitor deficiency. Clin Exp Immunol 2012; 167: 422-428

154. Zilberberg MD, Nathanson BH, Jacobsen T, Tillotson G. Descriptive epidemiology of hereditary angioedema hospitalizations in the United States, 2004-2007. Allergy Asthma Proc. 2011;32:248-254.

155. Tse KY, Zuraw BL, Chen Q, Christiansen SC. Anabolic androgen use in the management of hereditary angioedema: Not so cheap after all. Ann Allergy Asthma Immunol. 2017;118:456-60.

156. Bygum A, Aygören-Pürsün E, Caballero T, Beusterien K, Gholizadeh S, Musingarimi $\mathrm{P}$, et al. The hereditary angioedema burden of illness study in Europe (HAE-BOIS-Europe): background and methodology. BMC Dermatol. 2012;12:4. 


\section{Appendix}

\section{Written questionnaire children}

\section{ALLMÄNNA FRÅGOR}

1. Vem har fyllt i denna enkät? (Du kan krydda för ett eller flera alternativ!)

\begin{tabular}{l}
$\square$ Du (dvs. barnet, ungdomen) \\
\hline$\square$ Dina föräldrar: $\square$ Mor $\square$ Far \\
\hline$\square$ Föräldrarna tillsammans med barnet: $\square$ Mor $\square$ Far
\end{tabular}

2. Vilket år är $\underline{D u}$ född?

3. Kön: $\square$ Flicka $\square$ Pojke

4. Är $\underline{D u}$ född i Sverige?

$\square \mathrm{Ja}$

$\square$ Nej, Om nej: I vilket land är $\underline{D u}$ född?

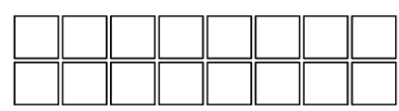

5. Är Dina föräldrar födda i Sverige?

Mor: $\square$ Ja $\square$ Nej, Om nej: I vilket land är $\underline{\text { Din }}$ mor född?

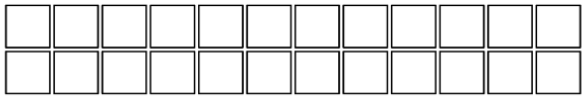

Far: $\square$ Ja Nej, Om nej: I vilket land är $\underline{\operatorname{Din}}$ far född?

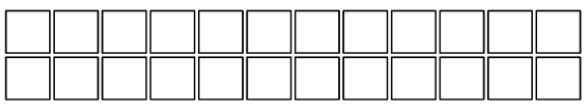

6. Hur många helsyskon har $\underline{D u}$ totalt?

7. Hur många halvsyskon har $\underline{D u}$ totalt?

8. Hur lång är $\underline{D u}$ ?

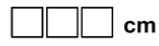

9. Hur mycket väger $\underline{D u}$ ?

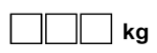


Till Dig som är flicka (pojkar fortsätter till fråga 11)

10. Har $\underline{D u}$ fått menstruation? $\square$ Ja $\square$ Nej

\section{DIN HÄLSA}

11. Har $\underline{D u}$ någonsin fått plötslig (inom timmar) svullnad i huden eller underhuden? (så kallade angioödem)

$\square$ Nej, Om Nej, fortsätt till fråga 13

$\square \mathrm{Ja}, \quad$ Om Ja, vid vilken ålder började detta? Vid $\square \square$ års ålder

\begin{tabular}{|c|c|c|c|}
\hline \multicolumn{2}{|c|}{$\begin{array}{l}\text { Om Ja, ange först på vilka ställen och sedan hur } \\
\text { hur många gånger någonsin } \underline{D u} \text { har haft svullnad }\end{array}$} & \multicolumn{2}{|c|}{$\begin{array}{l}\text { Hur många gånger har } \underline{D u} \text { haft } \\
\text { svullnad under senaste } 12 \text { månaderna }\end{array}$} \\
\hline Ansikte .................... totalt & ggr. & & ggr \\
\hline Armar....................... totalt & $\operatorname{ggr} \ldots$ & & ggr \\
\hline Ben ......................... totalt & ggr. & & ggr \\
\hline Bål (bröst, buk, rygg). totalt & ggr. & & ggr \\
\hline$\square$ Underlivet .................. totalt & ggr ... & & ggr \\
\hline
\end{tabular}

12. Har $\underline{D u}$ i samband med svullnad i huden och underhuden:

$\begin{array}{lllll}\square \text { haft rodnad i hudsvullnaderna } & \square \text { aldrig } & \square \text { ibland } & \square \text { ofta } & \square \text { allid } \\ \square \text { haft klåda i hudsvullnaderna } & \square \text { aldrig } & \square \text { ibland } & \square \text { ofta } & \square \text { alltid } \\ \square \text { haft smärta/värk i hudsvullnaderna } & \square \text { aldrig } & \square \text { ibland } & \square \text { ofta } & \square \text { alltid }\end{array}$

13. Har $\underline{D u}$ någonsin haft svullnad/ödem i slemhinnor?

$\square \mathrm{Nej}$

$\square$ Ja, Om ja, vid vilket ålder började detta? Vid $\square \square$ års ålder

\begin{tabular}{|c|c|c|c|}
\hline \multicolumn{2}{|c|}{$\begin{array}{l}\text { Om Ja, ange först på vilka ställen och sedan hur } \\
\text { hur många gånger någonsin } \underline{D u} \text { har haft svullnad }\end{array}$} & \multicolumn{2}{|c|}{$\begin{array}{l}\text { Hur många gånger har } \underline{D u} \text { haft } \\
\text { svullnad under senaste } 12 \text { månader }\end{array}$} \\
\hline Läppar ...................... totalt & ggr ... & & ggr \\
\hline Tunga ........................ totalt & ggr... & & ggr \\
\hline Svalg ....................... totalt & ggr... & & ggr \\
\hline Underliv ..................... totalt & ggr... & & ggr \\
\hline
\end{tabular}


14. Har $\underline{D} u$ någonsin haft något/några av nedanstående symptom?

Om ja, markera med kryss och ange hur många gånger någonsin, samt om $\underline{\mathrm{Du}}$ samtidigt har haft svullnad $i$ ansiktet, svalget el. gommen.

\begin{tabular}{|c|c|c|}
\hline \multicolumn{2}{|c|}{$\begin{array}{l}\text { Har } \underline{D u} \text { någonsin haft något/några av nedanstående } \\
\text { symptom? }\end{array}$} & $\begin{array}{l}\text { Har } \underline{D u} \text { samtidigt haft svullnad } \\
\text { i ansiktet, svalget el. gommen? }\end{array}$ \\
\hline Kvävningskänsla ..........totalt & ggr. & ] $\mathrm{Ja}$ \\
\hline Andningssvårigheter ....totalt & $\operatorname{ggr} \ldots$ & Ja \\
\hline Svimmat .....................totalt & ggr... & ] Ja \\
\hline Svårigheter att svälja ...totalt & ggr... & ] Ja \\
\hline$\square$ Heshet ........................totalt & ggr... & $\square \mathrm{Ja}$ \\
\hline
\end{tabular}

15. Har $\underline{D u}$ någonsin haft något/några av nedanstående tillstånd? Om ja, markera med kryss och ange hur många gånger

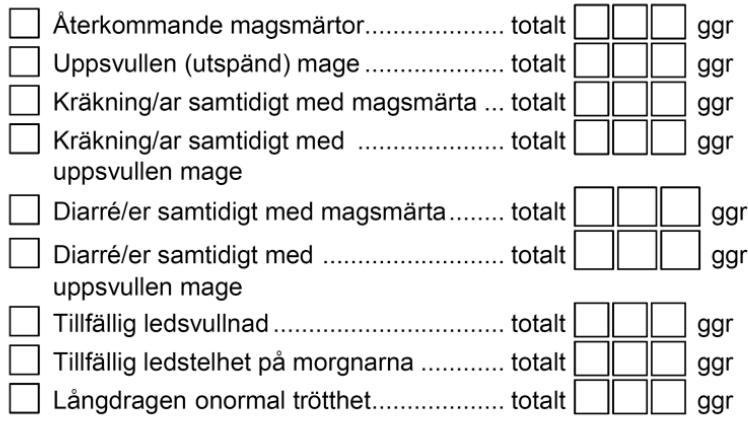

16. I allmänhet, hur skulle $\underline{D u}$ vilja säga att $\underline{D i n}$ hälsa är?

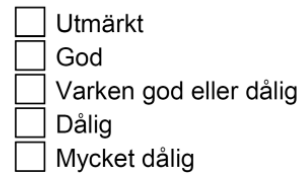

17. Har $\underline{D u}$ haft besvär i lederna (smärta, värk, obehag) någon gång under de senaste 12 månaderna?

$\mathrm{Nej}$

$\square \mathrm{Ja}, \quad$ Om ja, har detta varit $i$ samband med svullnad i huden? $\square \mathrm{Ja} \quad \square$ Nej 
18. Har Du haft svår huvudvärk?

$\mathrm{Nej}$

$\mathrm{Ja}, \quad$ Om ja, ange totalt hur många gånger: $\square \square \square$ ggr

\section{Ange hur huvudvärken har yttrat sig?}

19. Har $\underline{\text { u }}$ någonsin haft något/några av nedanstående symptom? Om ja, markera med kryss och ange om Du samtidigt har haft svullnadskänsla $i$ buken.

\begin{tabular}{|c|c|}
\hline $\begin{array}{l}\text { Har } \underline{D u} \text { någonsin haft något/några av nedanstående } \\
\text { symptom? }\end{array}$ & $\begin{array}{l}\text { Har } \underline{D u} \text { samtidigt haft svullnads- } \\
\text { känsla i buken? }\end{array}$ \\
\hline Smärta/sveda vid tömning av urinblåsa .. & Nej \\
\hline Kramper/huggkänsla i nedre delen av buken.. & $\mathrm{Nej}$ \\
\hline Känsla av ofullständig tömning av urinblåsan . & $\mathrm{Nej}$ \\
\hline Urinträngning ................... & Ja..... \\
\hline Dålig stråle vid tömning av urinblåsan .............. & $\mathrm{Ja} . . . . . . . \square \mathrm{Nej}$ \\
\hline
\end{tabular}

\section{Här nedan är några ansikten som uttrycker olika känslor.}

20. Vilket ansikte uttrycker bäst hur Du samt Dina föräldrar upplever $\underline{\operatorname{Din}}$ livskvalitet för närvarande (senaste veckan)?

Sätt ett kryss under en av figurerna.

Vad tycker:
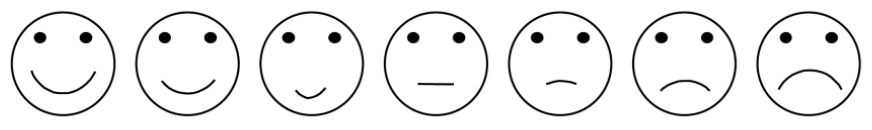

Du

Dina föräldrar
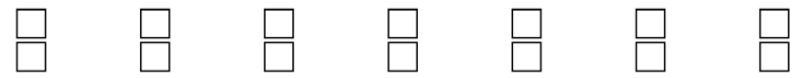
21. Har $\underline{D u}$ under de senaste 12 månaderna regelbundet tagit läkemedel i minst 1 månad?

$\square \mathrm{Nej}$

$\square \mathrm{Ja}, \quad$ Om ja, ange vilket/vilka läkemedel: (Ange helst preparatets namn)

1)

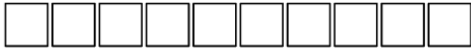

2)

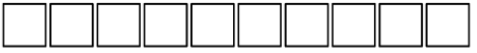

3)

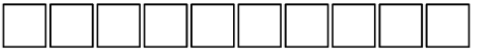

4)

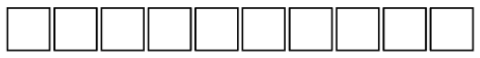

5)

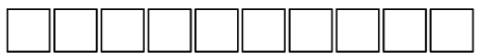

6)

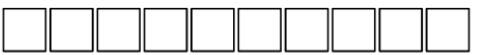

7)

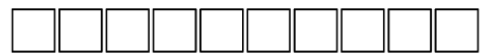

8)

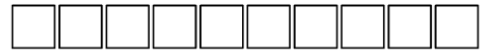

9)

22. Har $\underline{D u}$ någon gång under de senaste 12 månaderna regelbundet tagit några hälsokostpreparat?

$\square$ Nej

$\square \mathrm{Ja}, \quad$ Om ja, ange vilket/vilka:

1)

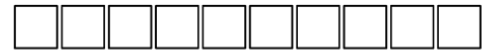

2)

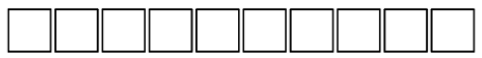

3)

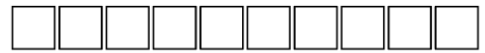

4)

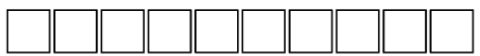

5)

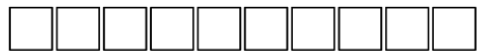


23. Har $\underline{D u}$ något av nedanstående tillstånd diagnostiserade av läkare?

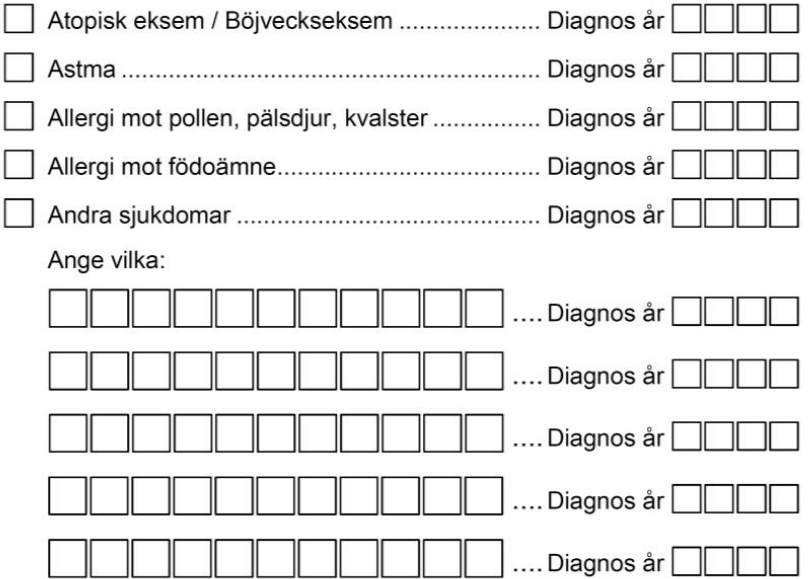

24. Har vaccinationer någonsin lett till problem?

Nej

Ja, hudsvullnad,

Om ja, ange vaccinations typ: $\square, \square, \square, \square, \square, \square, \square, \square, \square$

Ja, hudsvullnad som blev så uttalad att Ni rådfrågade läkare/BVC.

Om ja, ange vaccinations typ: $\square, \square, \square, \square, \square, \square, \square, \square$

Ja, allmän påverkan med feber.

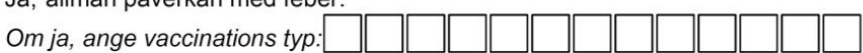

Ja, annat: $\quad \square \square \square \square \square \square \square \square \square \square, \square, \square, \square, \square$

Ange vaccinations typ: $\square, \square, \square, \square, \square, \square, \square, \square, \square$ 


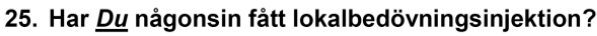

$\square \mathrm{Nej}$

$\mathrm{Ja}, \mathrm{Om}$ ja, ange var och om Du hade någon biverkan.

$\square$ i munnen

Ev. biverkan:

i huden

Ev. biverkan:

\section{UTLÖSANDE FAKTORER}

26. Har Du fått svullnad i huden eller underhuden i samband med något/några av nedanstående faktorer? Kryssa om något av nedanstående utlöst svullnad $\mathrm{i}$ :

\begin{tabular}{|c|c|c|c|c|c|c|}
\hline \multirow[b]{2}{*}{ Utlösande faktorer: } & \multicolumn{6}{|c|}{ I vilket/vilka organ fick Du svullnad? } \\
\hline & Huden & Läpparna & Tungan & Svalget & Buken & Underlivet \\
\hline$\square$ Trauma (fall, slag, etc) & $\square$ & $\square$ & $\square$ & $\square$ & $\square$ & $\square$ \\
\hline$\square$ Idrottsaktivitet & $\square$ & $\square$ & $\square$ & $\square$ & $\square$ & $\square$ \\
\hline $\begin{array}{l}\square \text { Luftvägsinfektion/ } \\
\text { förkylning }\end{array}$ & $\square$ & $\square$ & $\square$ & $\square$ & $\square$ & $\square$ \\
\hline$\square$ Körtelfeber & $\square$ & $\square$ & $\square$ & $\square$ & $\square$ & $\square$ \\
\hline$\square$ Ingrepp hos tandläkare & $\square$ & $\square$ & $\square$ & $\square$ & $\square$ & $\square$ \\
\hline$\square$ Tandborstning & $\square$ & $\square$ & $\square$ & $\square$ & $\square$ & $\square$ \\
\hline$\square$ Psykisk stress & $\square$ & $\square$ & $\square$ & $\square$ & $\square$ & $\square$ \\
\hline$\square$ Operation & $\square$ & $\square$ & $\square$ & $\square$ & $\square$ & $\square$ \\
\hline$\square$ Annat & $\square$ & $\square$ & $\square$ & $\square$ & $\square$ & $\square$ \\
\hline \multicolumn{7}{|c|}{ För flickor som har fått menstruation: } \\
\hline$\square$ Menstruation & $\square$ & $\square$ & $\square$ & $\square$ & $\square$ & $\square$ \\
\hline$\square$ P-piller & $\square$ & $\square$ & $\square$ & $\square$ & $\square$ & $\square$ \\
\hline
\end{tabular}




\section{ÄRFTLIGHET}

27. Finns det någon i Din släkt som av läkare fått diagnosen hereditärt (ärftligt) angioödem (HAE, HANE, HANÖ)?

$\square \mathrm{Nej}$

$\square \mathrm{Ja}$, Om ja, ange vem?

\begin{tabular}{|l}
$\square$ Mor $\square$ Morföräldrar \\
\hline$\square$ far \\
\hline$\square$ farföräldrar
\end{tabular}

$\square$ Någon annan i släkten, ange vem

\section{LIVSSTILSFRÅGOR:}

28. Ägnar $\underline{D u}$ dig åt motion av något slag inklusive skolgympan?

Som motion räknas idrott, konditionsträning, gymnastik och liknande under minst 30 minuter per tillfälle och så intensivt att $\underline{\mathrm{Du}}$ svettas eller blir varm.
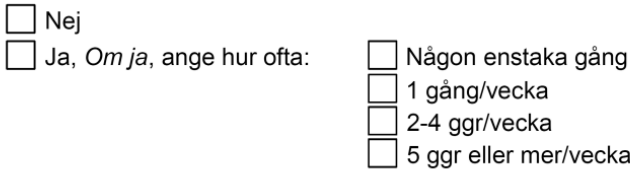

29. Förekommer rökning hemmet?

$\square$ Nej
$\square$ Ja, ibland
$\square$ Ja, dagligen

\section{SJUKFRÅNVARO (vissa frågor gäller tonåringar bara)}

30. Hur många dagar ungefär, har $\underline{D u}$ varit frånvarande från dagis/skolan på grund av sjukdom under de senaste 12 månaderna?

Totalt:
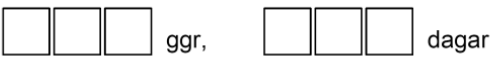
31. Har $\underline{D} u$ haft sjukfrånvaro på grund av någon/några av nedanstående tillstånd? Om ja, markera med kryss och ange sammanlagt hur många gånger och hur många dagar.

Svullnad i huden/underhuden
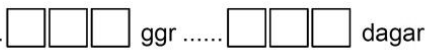
(så kallade angioödem)

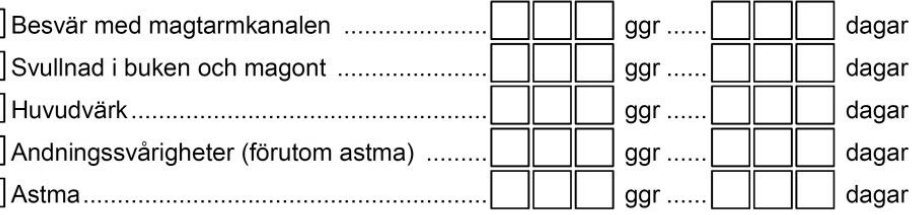

32. Har det hänt under de senaste 12 månaderna att $\underline{D u}$ gått till dagis/skolan, trots att Du med tanke på Ditt hälsotillstånd egentligen borde ha stannat hemma?

$\mathrm{Nej}$

Ja, Om ja, ange hur ofta:

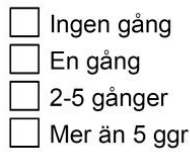

33. Sammanlagt hur många dagar ungefär, har Dina föräldrar varit frånvarande från arbetet för vård av Dig under de senaste 12 månaderna?

Totalt:

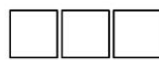

ggr,

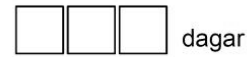

34. När Dina föräldrar har varit hemma för vård av Dig, vilket/vilka av nedanstående tillstånd hade $\underline{D u}$ ?

Om ja,markera med kryss och ange sammanlagt hur många gånger och hur många dagar.

Svullnad i huden/underhuden

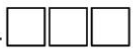

ggr .

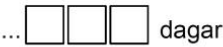
(så kallade angioödem)

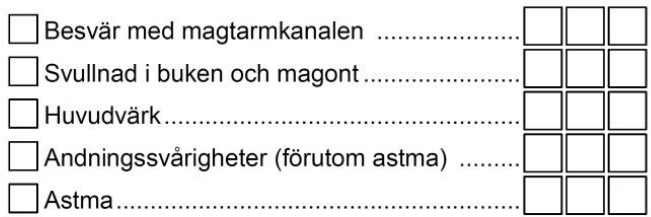

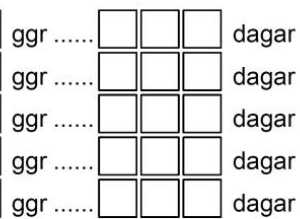




\section{Written questionnaire adults}

\section{ALLMÄNNA FRÅGOR}

1. Vilket år är Du född?

2. Kön:

Kvinna

Man

3. Är Du född i Sverige?

$\mathrm{Ja}$

Nej, Om nej: I vilket land är Du född?

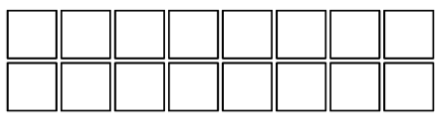

4. Är Dina föräldrar födda i Sverige?

Mor: $\square$ Ja

Nej, Om nej: I vilket land är Din mor född?

\begin{tabular}{|l|l|l|l|l|l|l|l|l|l||l||l||}
\hline & & & & & & & & & & & \\
\hline \hline
\end{tabular}

Far: $\square \mathrm{Ja}$ Nej, Om nej: I vilket land är Din far född?

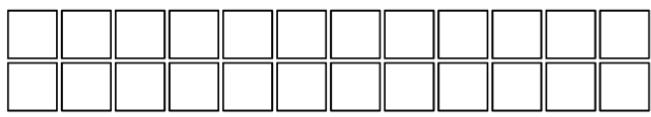

5. Har Du barn?

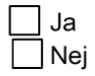

6. Hur är Din ekonomi?

$\square$ Mycket god
$\square$ God
$\square$ Varken god eller dålig
$\square$ Ansträngd
$\square$ Mycket ansträngd

7. Hur många helsyskon har Du totalt?

8. Hur många halvsyskon har Du totalt?

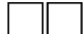


9. Hur lång är Du?

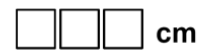

10. Hur mycket väger Du?

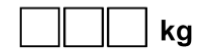

Till Dig som är kvinna (män fortsätter till fråga 13)

11. Hur många barn har Du fött? st.

12. Är Du gravid nu?

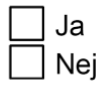

\section{DIN HÄLSA}

13. Har Du under de senaste 12 månaderna fått plötslig (inom timmar) svullnad $i$ huden eller underhuden? (så kallade angioödem)

Nej, Om Nej, fortsätt till fråga 15

Ja, Om Ja, vid vilken ålder började detta? Vid $\square \square$ års ålder

Om Ja, ange först på vilka ställen och sedan hur många gånger sammanlagt som Du har haft svullnad under de senaste 12 månaderna:

\begin{tabular}{|c|c|}
\hline Ansikte ..................... totalt & ggr under de senaste 12 månaderna \\
\hline Händer........................ totalt & ggr under de senaste 12 månaderna \\
\hline Armar......................... totalt & ggr under de senaste 12 månaderna \\
\hline Fötter ........................ totalt & ggr under de senaste 12 månaderna \\
\hline Ben ......................... totalt & ggr under de senaste 12 månaderna \\
\hline Bål (bröst, buk, rygg) ... totalt & ggr under de senaste 12 månaderna \\
\hline Underliv ...................... totalt & ggr under de senaste 12 månaderna \\
\hline
\end{tabular}

14. Har Du i samband med svullnad i huden och underhuden:

\begin{tabular}{|c|c|c|c|}
\hline haft rodnad i hudsvullnaderna & aldrig & ibland & ofta \\
\hline haft klåda i hudsvullnaderna & aldrig & ibland & ofta \\
\hline haft smärta/värk i hudsvullnaderna & aldrig & ibland & ofta \\
\hline
\end{tabular}




\section{Har Du någonsin haft svullnad/ödem i slemhinnor?}

$\square$ Nej

Ja, Om ja, vid vilket ålder började detta? Vid $\square \square$ års ålder

Om Ja, ange först på vilka ställen och sedan hur många gånger sammanlagt som Du har haft svullnad under de senaste 12 månaderna:

\begin{tabular}{|c|c|}
\hline Läppar .......................totalt & ggr under de senaste 12 månaderna \\
\hline Tunga ........................ totalt & ggr under de senaste 12 månaderna \\
\hline Svalg.......................... totalt & ggr under de senaste 12 månader \\
\hline Underliv .......................totalt & ggr under de senaste 12 månaderr \\
\hline
\end{tabular}

16. Har Du under de senaste 12 månaderna haft något/några av nedanstående symptom?

Om ja, ange hur många gånger samt om Du har haft samtidigt svullnad $i$ ansiktet, svalget el. gommen.

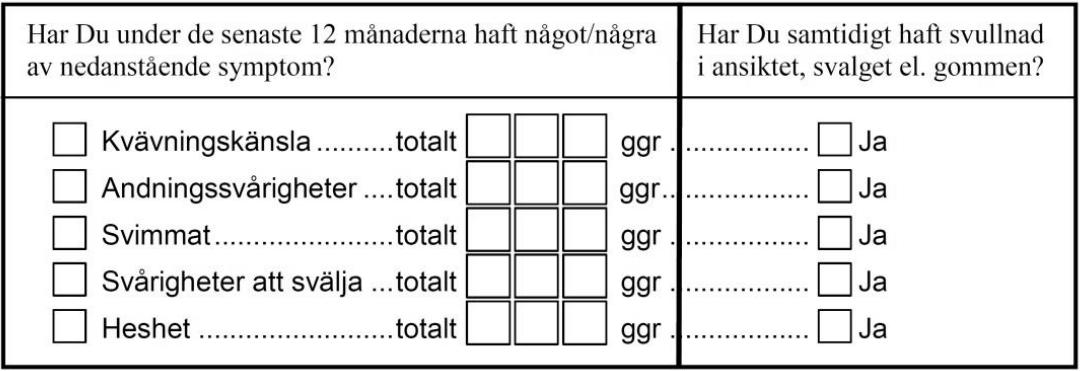

17. Har Du någonsin haft något/några av nedanstående tillstånd? Om ja, markera med kryss och ange hur många gånger under de senaste 12 månaderna!

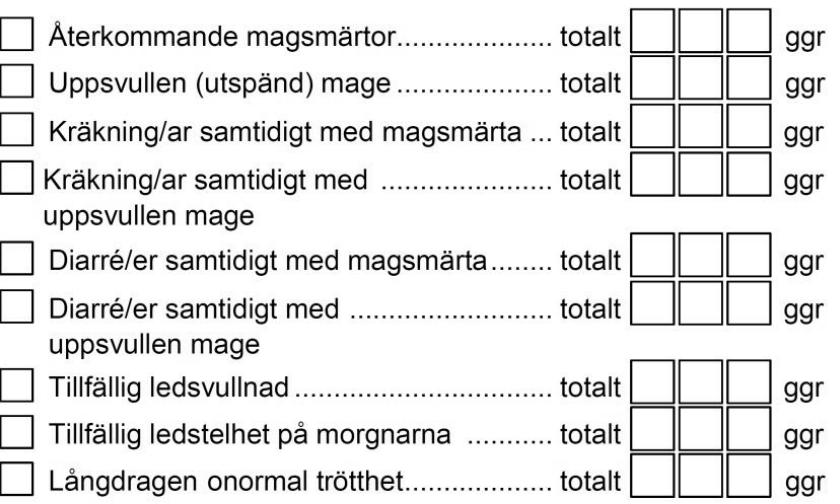


18. I allmänhet, hur skulle Du vilja säga att Din hälsa är?

\begin{tabular}{l}
$\square$ Utmärkt \\
\hline$\square$ God \\
\hline Varken god eller dålig \\
\hline Dålig \\
\hline$\square$ Mycket dålig
\end{tabular}

19. Har Du haft svår huvudvärk under de senaste 12 månaderna?

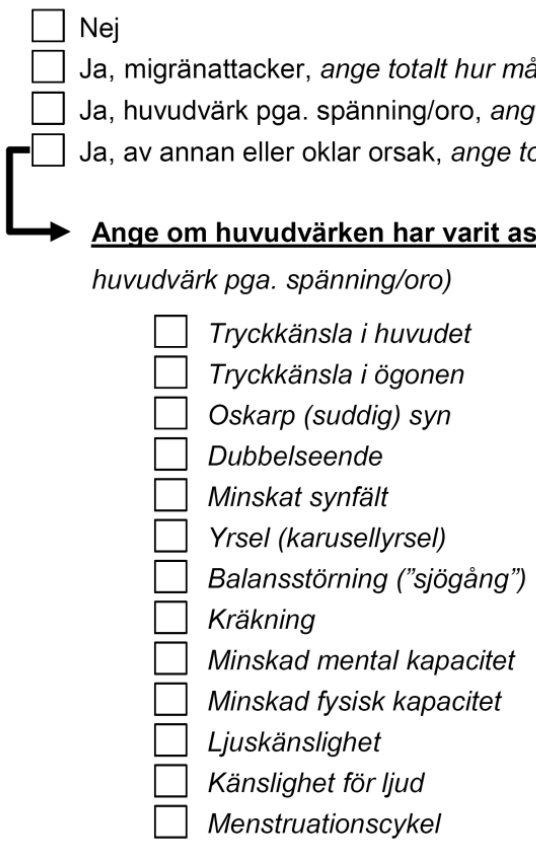

20. Har Du någonsin haft något/några av nedanstående symptom? Om ja, markera med kryss och ange om Du har haft samtidigt svullnadskänsla i buken eller ej.

\begin{tabular}{|c|c|}
\hline $\begin{array}{l}\text { Har Du någonsin haft något/några av nedanstående } \\
\text { symptom? }\end{array}$ & $\begin{array}{l}\text { Har Du samtidigt haft svullnads- } \\
\text { känsla i buken? }\end{array}$ \\
\hline Smärta/sveda vid tömning av urinblåsa .......... & $\mathrm{Ja} . .$. \\
\hline Kramper/huggkänsla i nedre delen av buken... & ] Ja..... \\
\hline Känsla av ofullständig tömning av urinblåsan .. & ] Ja...... \\
\hline Urinträngning ................. & Ja....... $\square$ Nej \\
\hline Dålig stråle vid tömning av urinblåsan & $\square$ Ja........ $\square$ Nej \\
\hline
\end{tabular}


Här nedan är några ansikten som uttrycker olika känslor.

21. Vilket ansikte uttrycker bäst hur Du upplever Din livskvalitet för närvarande (senaste veckan)?

Sätt ett kryss under en av figurerna.
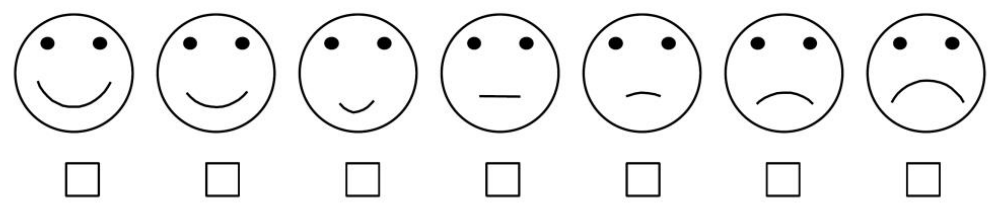

22. Har Du under de senaste 12 månaderna haft så pass svåra bröstsmärtor att Du varit tvungen att avbryta det Du håller på med?

$\square \mathrm{Ne}$
$\square \mathrm{Ja}$

Om ja, ange totalt hur många gånger:

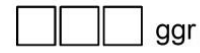

Ange om bröstsmärtan har varit förenad med:

$\square$ Tryck i bröstet
$\square$ Kvävningskänsla
$\square$ Andningssvårigheter
$\square$ Oförmåga att ta djupa andetag
$\square$ Sväljningssvårigheter
$\square$ Kärlkramp
$\square$ Hjärtinfarkt
$\square$ "Sura" uppstötningar
$\square$ Matstrupsbråck

23. Har Du haft besvär i lederna någon gång under de senaste 12 månaderna? Om ja, ange i vilka leder, samt om Du har haft smärta, svullnad eller stelhet.

$\begin{array}{llccc}\square & \text { Smärta } & \text { Svullnad } & \underline{\text { Stelhet }} \\ \square & \text { Skuldror/axlar/armbågar } & \square & \square & \square \\ \square & \text { Handleder/händer } & \square & \square & \square \\ \square & \text { Ryggen } & \square & \square & \square \\ \square & \text { Höfter eller knän } & \square & \square & \square \\ \square & \text { Fötter eller fotleder } & \square & \square & \square\end{array}$


24. Har Du under de senaste 12 månaderna regelbundet tagit läkemedel i minst 1 månad?

$\square \mathrm{Nej}$

$\mathrm{Ja}, \quad$ Om ja, ange vilket/vilka läkemedel: (Ange helst preparatets namn)

1)

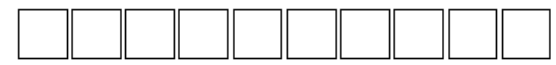

2)

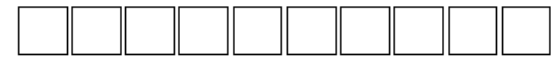

3)

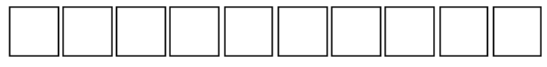

4)

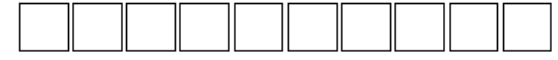

5)

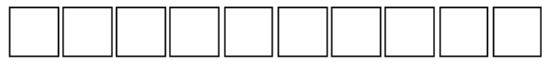

6)

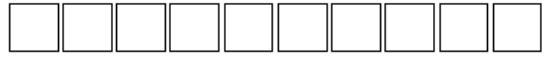

7)

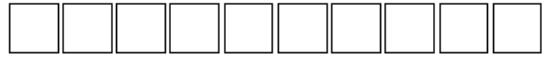

8)

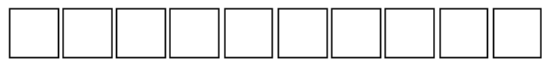

9)

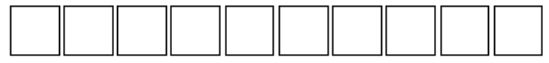

25. Har Du någon gång under de senaste 12 månaderna regelbundet tagit några hälsokostpreparat?

$\mathrm{Nej}$

$\square \mathrm{Ja}, \quad$ Om ja, ange vilket/vilka:

1)

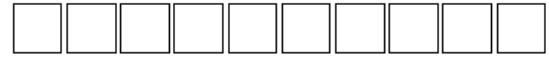

2)

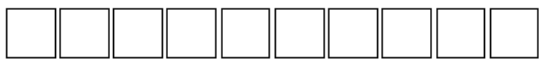

3)

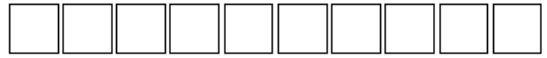

4)

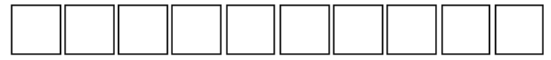

5)

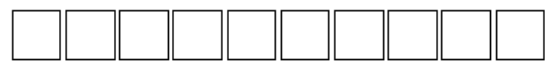


26. Har Du något av nedanstående tillstånd diagnostiserade av läkare?

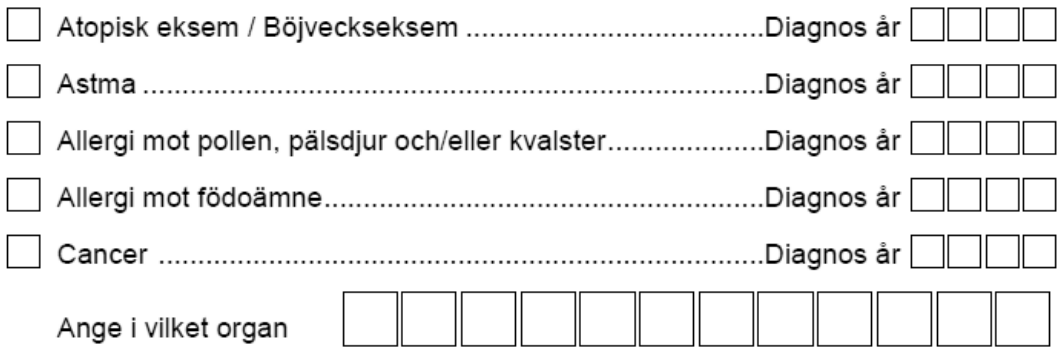

$\square$ Stroke: blödning el. blodpropp i hjärnan Diagnos år $\square \square \square \square$

Hjärtinfarkt Diagnos år $\square \square \square \square$

Kärlkramp i hjärtat ..Diagnos år $\square \square \square \square$

$\square$ Högt blodtryck (även behandlat) Diagnos år $\square \square \square \square$

$\square$ Kärlkramp i benen Diagnos år $\square \square \square \square$

$\square$ Blodpropp i benen Diagnos år $\square \square \square \square$

$\square$ Magsår Diagnos år $\square \square \square \square$

$\square$ Ledgångsreumatism (RA)... Diagnos år $\square \square \square \square$

$\square$ SLE (Systemisk lupus erythematosus) Diagnos år $\square \square \square \square$

$\square$ Sockersjuka som tablettbehandlas Diagnos år $\square \square \square \square$

$\square$ Sockersjuka som insulinbehandlas. Diagnos år $\square \square \square \square$

Sockersjuka under graviditet Diagnos år $\square \square \square \square$ Ulcerös kolit Diagnos år $\square \square \square \square$ Crohns sjukdom. Diagnos år $\square \square \square \square$ $\square$ Överproduktion av sköldkörtelhormon (giftstruma) ............ Diagnos år $\square \square \square \square$ $\square$ Underproduktion av sköldkörtelhormon (hypotyreos) ........Diagnos år $\square \square \square \square$ $\square$ Ögoninflammationer (irit = regnbågshinneinflammation) . .Diagnos år $\square \square \square \square$ $\square$ Vitiligo Diagnos år $\square \square \square \square$ Vitamin B12-brist Diagnos år $\square \square \square \square$ 
27. Har Du blivit vaccinerad under de senaste 12 månaderna?

$\square$ Nej

Ja, Om ja, ange mot vad? Ange om Du hade någon biverkan av vaccinet.

1.

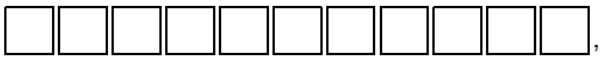

Ev. biverkan:

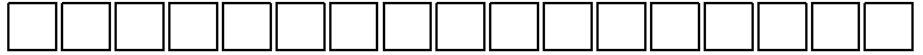

2.

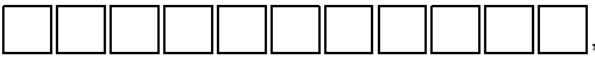

Ev. biverkan

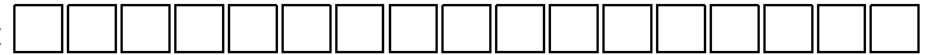

3.

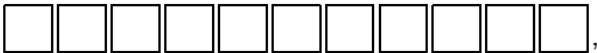

Ev. biverkan:

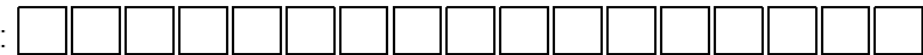

28. Har Du fått lokalbedövningsinjektion under de senaste 12 månaderna?

$\square \mathrm{Nej}$

Ja, Om ja, ange var och om Du hade någon biverkan.

i munnen

Ev. biverkan:

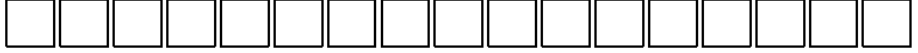

$\square$ i huden

Ev. biverkan:

\section{ÄRFTLIGHET}

29. Finns det någon i Din släkt som av läkare fått diagnosen hereditärt (ärftligt) angioödem (HAE, HANE, HANÖ)?

$\square$ Nej

$\square$ Ja, Om ja, ange vem?

\begin{tabular}{ll}
$\square$ Mor $\quad \square$ Morföräldrar \\
\hline$\square$ Far $\quad \square$ Farföräldrar \\
\hline$\square$ Barn $\quad \square$ Barnbarn \\
\hline$\square$ Syskon \\
\hline$\square$ Någon annan i släkten, ange vem
\end{tabular}

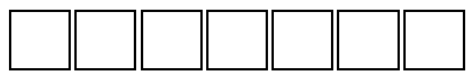




\section{UTLÖSANDE FAKTORER}

30. Har Du fått svullnad, och i så fall var, i samband med något/några av nedanstående? Markera med kryss!

\begin{tabular}{|c|c|c|c|c|c|c|}
\hline \multirow[b]{2}{*}{ Utlösande faktorer: } & \multicolumn{6}{|c|}{ I vilket/vilka organ fick Du svullnad? } \\
\hline & Huden & Läpparna & Tungan & Svalget & Buken & Underlivet \\
\hline$\square$ Trauma (fall, slag, etc) & $\square$ & $\square$ & $\square$ & $\square$ & $\square$ & $\square$ \\
\hline$\square$ Idrottsaktivitet & $\square$ & $\square$ & $\square$ & $\square$ & $\square$ & $\square$ \\
\hline $\begin{array}{l}\square \text { Luftvägsinfektion/ } \\
\text { förkylning }\end{array}$ & $\square$ & $\square$ & $\square$ & $\square$ & $\square$ & $\square$ \\
\hline$\square$ Körtelfeber & $\square$ & $\square$ & $\square$ & $\square$ & $\square$ & $\square$ \\
\hline$\square$ Ingrepp hos tandläkare & $\square$ & $\square$ & $\square$ & $\square$ & $\square$ & $\square$ \\
\hline$\square$ Tandborstning & $\square$ & $\square$ & $\square$ & $\square$ & $\square$ & $\square$ \\
\hline$\square$ Psykisk stress & $\square$ & $\square$ & $\square$ & $\square$ & $\square$ & $\square$ \\
\hline$\square$ Operation & $\square$ & $\square$ & $\square$ & $\square$ & $\square$ & $\square$ \\
\hline $\begin{array}{c}\square \text { Undersökning med } \\
\text { tunn kameraoptik } \\
\text { t.ex. gastroskopi }\end{array}$ & & ५ & L & L & 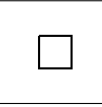 & 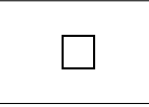 \\
\hline $\begin{array}{l}\square \text { Behandling hos } \\
\text { hudterapeut }\end{array}$ & 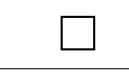 & $\square$ & $\square$ & $\square$ & $\square$ & $\square$ \\
\hline$\square$ P-piller & $\square$ & $\square$ & $\square$ & $\square$ & $\square$ & $\square$ \\
\hline$\square$ Hormonspiral & $\square$ & $\square$ & $\square$ & $\square$ & $\square$ & $\square$ \\
\hline $\begin{array}{l}\square \text { Östrogen mot } \\
\text { klimakteriebesvär }\end{array}$ & ${ }^{-}$ & $\square$ & $\square$ & - & $\square$ & $\square$ \\
\hline$\square$ Ägglossning & $\square$ & $\square$ & $\square$ & $\square$ & $\square$ & $\square$ \\
\hline$\square$ Menstruation & $\square$ & $\square$ & $\square$ & $\square$ & $\square$ & $\square$ \\
\hline$\square$ Samlag & $\square$ & $\square$ & $\square$ & $\square$ & $\square$ & $\square$ \\
\hline$\square$ Graviditet & $\square$ & $\square$ & $\square$ & $\square$ & $\square$ & $\square$ \\
\hline$\square$ Förlossning & $\square$ & $\square$ & $\square$ & $\square$ & $\square$ & $\square$ \\
\hline$\square$ Annat, ange vad: & & & - & & L & \\
\hline
\end{tabular}




\section{LIVSSTILSFRAGOR:}

31. Röker Du?

$\square$ Ja, jag röker dagligen

$\square$ Ja, jag röker ibland

$\square$ Nej, jag har slutat. I så fall, vilket âr slutade Du? $\square \square \square \square$

$\square$ Nej, jag har aldrig varit rökare

Om ja,

Hur många cigaretter/cigarrer/pipstopp per dag i genomsnitt?

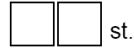

Hur många âr har Du rökt sammanlagt?

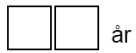

32. Snusar Du? $\square$ Ja, jag snusar dagligen

$\square$ Ja, jag snusar ibland

$\square$ Nej, jag har slutat. I så fall, vilket år slutade Du?

$\square$ Nej, jag har aldrig snusat

Om ja,

Hur många gånger per dag i genomsnitt?

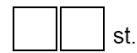

Hur mânga år har Du snusat sammanlagt?

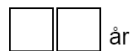

Instruktioner: Här följer några frågor om dina alkoholvanor. Vi är tacksamma om Du besvarar dem să noga som möjligt genom att markera det alternativ som gäller Dig.

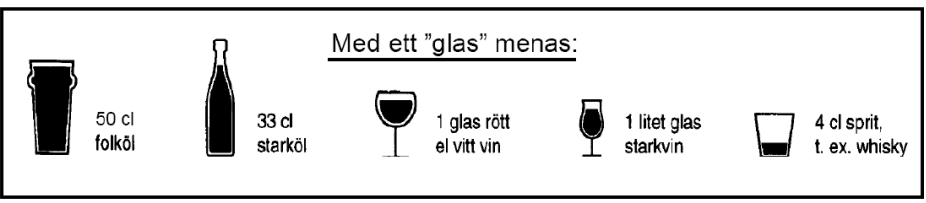

33. Hur ofta dricker Du alkohol?

\begin{tabular}{|c|c|c|c|c|}
\hline Aldrig & $\begin{array}{l}1 \text { gång i månaden } \\
\text { eller mer sällan } \\
\square\end{array}$ & $\begin{array}{c}2-4 \text { gånger } \\
\text { i månaden } \\
\square\end{array}$ & $\begin{array}{c}2-3 \text { gånger } \\
\text { i veckan } \\
\square\end{array}$ & $\begin{array}{c}4 \text { gånger/veckan } \\
\text { eller mer } \\
\square\end{array}$ \\
\hline
\end{tabular}

34. Hur många "glas" (se exempel ovan), dricker Du en typisk dag om Du dricker alkohol?
$1-2$
$\square$ 3-4
$\square 5-6$
7-9
10 eller mer 
35. Ägnar Du dig åt motion av något slag (inklusive eventuellt skolgympa)?

Som motion räknas idrott, konditionsträning, gymnastik och liknande under minst 30 minuter per tillfälle och sá intensivt att Du svettas eller blir varm.

\begin{tabular}{|c|c|}
\hline \multicolumn{2}{|l|}{ Nej } \\
\hline Ja, Om ja, ange hur ofta: & Någon enstaka gång \\
\hline & 1 gång/vecka \\
\hline & 2-4 ggr/vecka \\
\hline & 5 ggr eller mer/vecka \\
\hline
\end{tabular}

\section{SJUKFRANVARO}

36. Hur många dagar ungefär, har Du varit frånvarande från arbetet på grund av sjukdom under de senaste 12 månaderna?

Totalt under de senaste 12 månaderna:

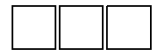

ggr,

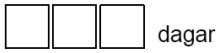

37. Har Du haft sjukfrånvaro på grund av någon/några av nedanstående tillstånd? Om ja, markera med kryss och ange hur många gånger och hur många dagar sammanlagt

$\square$ Svullnad i huden/underhuden (sả kallade angioödem)

$\square$ Besvär i magtarmkanalen

$\square$ Svullnad i buken och magont.

$\square$ Huvudvärk

$\square$ Andningssvårigheter (förutom astma)

Astma
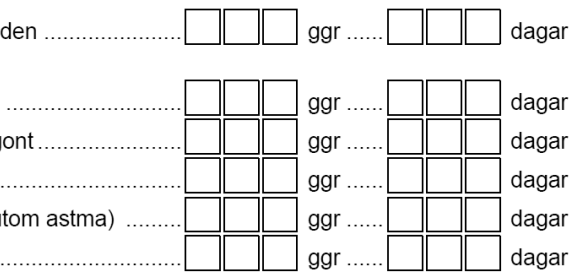

38. Har det hänt under de senaste 12 månaderna att Du gått till arbetet, trots att $\mathrm{Du}$ med tanke på Ditt hälsotillstånd egentligen borde ha stannat hemma?

$\square$ Nej

$\square$ Ja, Om ja, ange hur ofta

$\square$ Ingen gång
$\square$ En gång
$\square$ 2-5 gånger
$\square$ Mer än 5 gånger


Structured phone interview

\section{ALLMÄN INFORMATION}

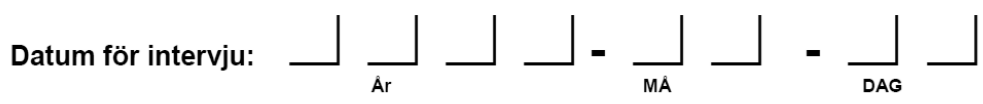

Patient studie -ID: $\downarrow-\rfloor$ Familje -ID: $\downarrow\rfloor$

Patientens namn:

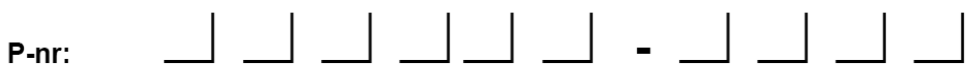

Pat:s adress:

Pat:s postnr, ort:

Pat:s tfn:

Behandlande läkare: Dr.

Vet ej

Klinik, adress:

$\square$ Vet ej

Tfn till läkaren:

Vet ej 


\section{DIAGNOS}

1. Alder vid debut av symptom: $\_-\downarrow$ år

2. Alder vid HAE-diagnos: $\_\_$àr

\section{KLINIK}

3. Hur många attacker per år har patienten i genomsnitt.?
$\square$ Inga
$\square 1-5$
$\square$ 6-11
$12-24$
$\square>24$

4. Från vilka organ brukar patienten får symptom?

\begin{tabular}{lll}
$\square$ Hud & $\square$ Läppar & $\square$ Buk $\quad \square$ Tunga \\
\hline Larynx & $\square$ Urogenitalomr. & $\square$
\end{tabular}

5. Har patienten någon föraning före attacken? $\square$ Ja $\square$ Nej

Vilken:

\section{När patienten har varit som sämst}

6. Ange attackfrekvens:

ggr/v

ggr/ månad

ggr/år

Kontinuerligt besvär i flera veckor, ange i så fall antal dagar

7. Hur länge varade attacken/erna?

$\square<12$ tim

$12-24$ tim

$\square 2-5$ dygn

$>5$ dygn

8. Hur mycket brukar svullnaderna klia?

$\square$ inget

$\square$ lätt

$\square$ måttligt

$\square$ svårt 
9. Hur ont har svullnaderna gjort?

$\square$ ingen $\square$ lätt $\quad \square$ måtllig $\quad \square$ svår

10. Vad brukar utlösa/försämra HAE-symptom?(rangordna)

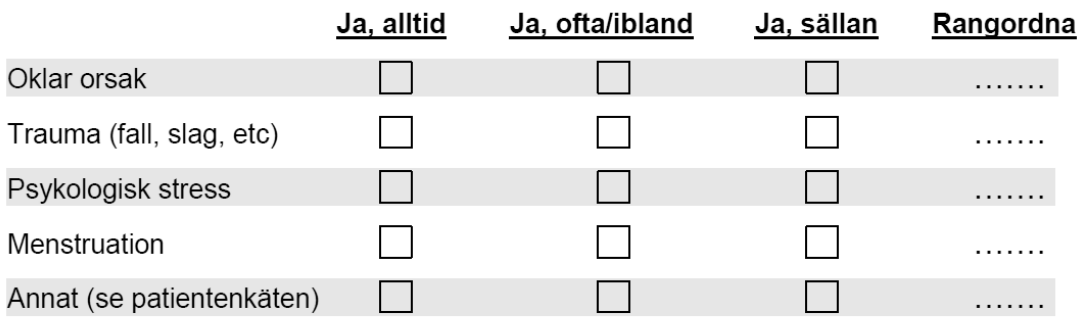

11. Hur många gånger har patienten

a) sökt vård pga. HAE? ..........ggr, specificera orsaken

b) blivit inlagd på sjukhus pga. HAE? ggr, specificera orsaken

12. Har patienten genomgått kirurgiska åtgärder pga. HAE?

$\square \mathrm{Nej}$

Ja, om ja ange vilka och var:

$$
\begin{aligned}
& \text { Var? } \\
& \text { Var? } \\
& \text { Var? } \\
& \text { Var? }
\end{aligned}
$$

13. Har HAE inskränkt patientens arbetsförmåga? $\square$ Ja $\square$ Nej

14. Har HAE inskränkt patientens sociala liv? $\square \mathrm{Ja} \quad \square \mathrm{Nej}$ 
15. Har patienten hypertension, diagnostiserad av läkare?

$\square$ Ja, ange i så fall:

Diagnosår

Behandling:

$\square$ Nej

16. Har patienten någon av nedanstående sjukdomar diagnostiserade av läkare senaste 2 år?

\begin{tabular}{|c|c|}
\hline Urogenitala: & ange vad. \\
\hline Renala: & ange vad. \\
\hline Gastrointestinala: & ange vad. \\
\hline Osteoartikulära: & ange vad. \\
\hline Neoplastiska: & ange vad. \\
\hline \multicolumn{2}{|c|}{ Neuropsykiatriska: ange vad.. } \\
\hline Infektiösa: & ange vad. \\
\hline Andra genetiska: & ange vad ... \\
\hline Metabola: & ange vad. \\
\hline Pulmonella: & 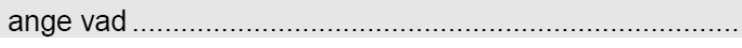 \\
\hline Hematologiska: & ange vad. \\
\hline Immunologiska: & ange vad. \\
\hline
\end{tabular}

17. Uppskatta patientens sjukdomsaktivitet (global skattning) under de senaste 12 månaderna.

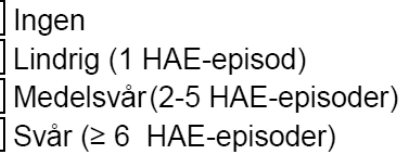

18. Uppskatta sjukdoms förlopp över åren:

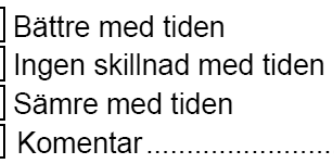




\section{Behandling akut}

19. Ange vilka behandlingar som patienten har erhållit under akuta svåra attacker, ange vilka organ det gäller och hur effektiv behandlingen har varit.

Effekt: $0=$ Ingen effekt $\quad 1$ = svag effekt $\quad 2=$ Måttligt effekt $\quad 3=$ Mycket bra effekt

C1-INH-koncentrat

\begin{tabular}{|c|c|c|c|c|c|c|c|}
\hline \multicolumn{2}{|c|}{ Hud } & \multicolumn{2}{|c|}{ Buk } & \multicolumn{2}{|c|}{ Laryngeal } & \multicolumn{2}{|c|}{ Urogenital } \\
\hline ggr & effekt & ggr & effekt & ggr & effekt & ggr & fffel \\
\hline
\end{tabular}

Färskfrusen plasma

Cyklokapron

Androgen (Danazol)

Androgen (Oxandrin)

Androgen (Stanozolol)

Respirator/intubation/

trakeotomi

Antihistaminer

Adrenalin

Glukokortikosteroider

Naprosyn

Voltaren

Andra NSAID

Diuretika

Vila

Annat, ange vad?

20. Har patienten $\mathrm{C} 1 \mathrm{INH}$ hemma?

$\mathrm{Nej}$

Ja, ange i så fall hur detta administreras?

pat. injicerar sig själv

pat. fâr injektioner av en anhörig

pat. får injektioner av sjukvårdspersonal 


\section{Behandling underhåll}

21. Har patienten erhållit nedanstående som underhållsbehandling?

Om ja kryssa för hur effektiv behandlingen har varit. Om nej kryssa för ev. orsaker.

\begin{tabular}{|c|c|c|c|c|c|c|}
\hline & \multicolumn{3}{|c|}{ Ange effekten: } & \multicolumn{3}{|c|}{ Ej använt, ange orsaken? } \\
\hline & $\begin{array}{c}\text { Bra } \\
1 \text { episod/ár } \\
\end{array}$ & $\begin{array}{c}\text { Máttligt } \\
\text { 2-5 episod/âr }\end{array}$ & $\begin{array}{c}\begin{array}{c}\text { Ingen } \\
\geq 6 \text { episod/ar }\end{array} \\
\end{array}$ & Kontraindik. & Pat avböjt & Okänd \\
\hline \multicolumn{7}{|l|}{ Androgener } \\
\hline \multicolumn{7}{|l|}{$\mathrm{C} 1 \mathrm{INH}$} \\
\hline Antifibrinolytikum & & & & & & \\
\hline
\end{tabular}

22. Ange effekten av nedanstående som underhållsbehandling.

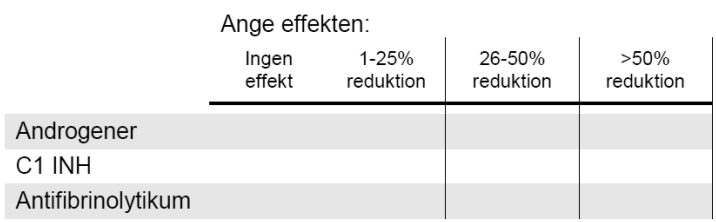

23. Har patienten tvungen att avbryta sin underhållsbehandling? Ange $i$ så fall orsaken.

\begin{tabular}{|c|c|c|c|c|}
\hline & $\begin{array}{c}\text { Insättning } \\
\text { mm/åå }\end{array}$ & $\begin{array}{l}\text { Utsättning } \\
\text { mm/åå }\end{array}$ & $\begin{array}{l}\text { Antal år } \\
\text { med beh. }\end{array}$ & $\begin{array}{l}\text { Ange orsaken till utsättning av } \\
\text { behandling: }\end{array}$ \\
\hline Androgener & ............ & $\ldots . . . . .$. & & \\
\hline $\mathrm{C} 1 \mathrm{INH}$ & $\ldots . . . . \ldots$ & $\ldots . \mid \ldots \ldots$ & & \\
\hline Antifibrinolytikum & $\ldots . . / \ldots \ldots$ & $\ldots . \mid \ldots \ldots$ & & \\
\hline
\end{tabular}

24. Erhåller patienten för närvarande något av nedanstående?

Stanozolol........ange minimal effektiv dos:

\begin{tabular}{|l|l|l|l|l|l|}
\hline 2 & 2,5 & 5 & 10 & $\ldots .$. & $\mathrm{mg}$ \\
\hline
\end{tabular}

Danazol ...........ange minimal effektiv dos:

\begin{tabular}{|l|l|ll|l|l|}
\hline 50 & 100 & 200 & 400 & $\ldots$. & $\mathrm{mg}$ \\
\hline
\end{tabular}

Oxandrolon .... ange minimal effektiv dos:

\begin{tabular}{|l|l|ll|l|l|}
\hline 2,5 & 5 & 10 & 20 & $\ldots .$. & $\mathrm{mg}$ \\
\hline
\end{tabular}

Nej, i så fall fortsätt med fråga 26 
25. Vilka biverkningar har patienten haft pga. behandling med androgener?

$\square$ Viktuppgång

$\square$ Acne

Hepatit

Virilisering

Förändrat libido

Myalgia

$\square$ Ändrad lipoproteinprofi

Oregelbunden menstruation

26. Erhâller patienten för närvarande Tranexamsyra?

Ja, i så fall ange dos/dag

\begin{tabular}{l|l|l|l|l|}
2 & 3 & 4 & $\ldots$. & $\mathrm{gr}$ \\
\hline
\end{tabular}

Nej, i så fall fortsätt med fråga 29

27. Har patienter fâtt biverkan pga. behandling med antifibrinolytikum?

Ja, i så fall specificera:

Nej

28. Erhåller patienten för närvarande $\mathrm{C} 1 \mathrm{INH}$ profylaktiskt?

$\square$ Nej, i så fall fortsätt med fråga 31

$\mathrm{Ja}$

Om ja,

Ange doser per infusion?

Ange infusionsintervallet?

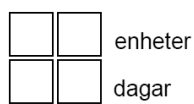

29. Används C1 INH inför nảgot av nedanstảende tillfälle?

Behandling hos tandläkare/tandhygienist

Operationer

Graviditet

Semester

Arbetsresor

Annat 
30. Har patienter fått biverkan pga. behandling med $\mathrm{C} 1 \mathrm{INH}$ ?

Ja, i så fall specificera:

Nej

\section{Hereditet}

31. Har någon i patientens släkt HAE?

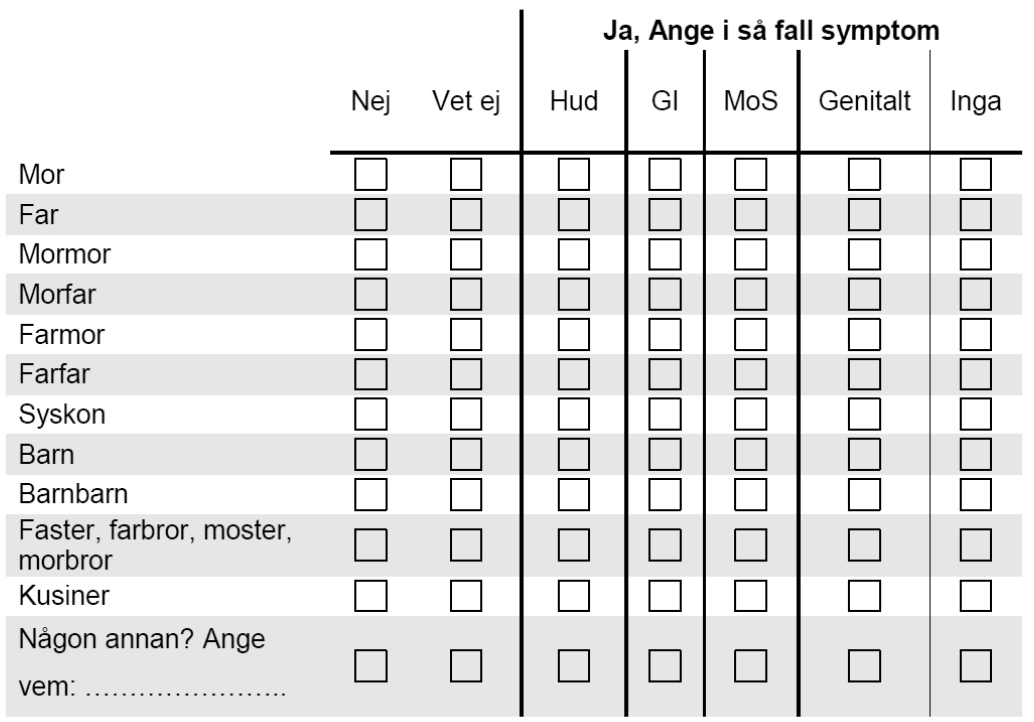

32. Har någon i patientens släkt avlidit pga HAE?

$\square$ Nej $\square$ Ja, Om ja, ange vem?

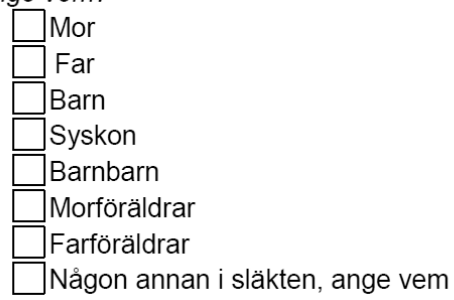




\section{ÖVRIGA FRAGOR}

33. Har patienten avstått från att skaffa egna barn för att inte riskera föra HAE vidare?

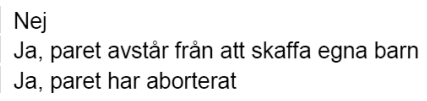

\section{Gäller för kvinnliga patienter:}

34. Hur gammal var patienten vid första mens? ..år

35. Blev HAE-symptom: Sämre Ingen skillnad Bättre

HAE hade ännu inte debuterat

36. Har menstruationerna upphört helt?
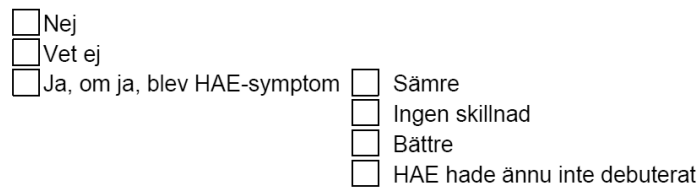

37. Har patienten ätit P-piller som innehåller östrogen?

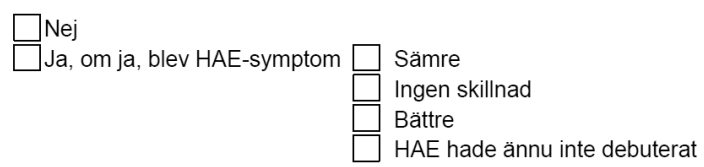

38. Har patienten ätit P-piller som innehåller gestagen?

$\square$ Nej
$\square$ Ja, om ja, blev HAE-symptom $\square$ Sämre
$\square$ Ingen skillnad
$\square$ Bättre
$\square$ HAE hade ännu inte debuterat




\section{Har patienten haft en spiral?}

Nej

Ja, om ja, ange vilken typ HAE-symptom blev:

Ingen skillnad

Bättre

HAE hade ännu inte debuterat

40. Har patienten varit gravid?

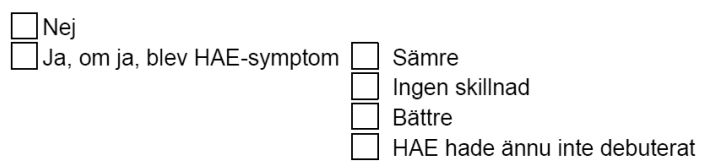

41. Uppstod några förlossningskomplikationer?

$\mathrm{Nej}$

Ja, $\square$ HAE-symptom

Annat, specificera

42. Är du förlöst med kejsarsnitt?

Nej

$\mathrm{Ja}$, om ja ange antal ggr samt orsaken?

ggr, orsak:

HAE

Annat, specificera

43. Har patienten haft några missfall?

Nej

Ja, om ja ange antal ggr samt orsaken?

ggr, orsak:

Okänd

Känd, specificera 


\section{Papers}

The papers associated with this thesis have been removed for copyright reasons. For more details about these see:

http://urn.kb.se/resolve?urn=urn:nbn:se:liu:diva-142207 